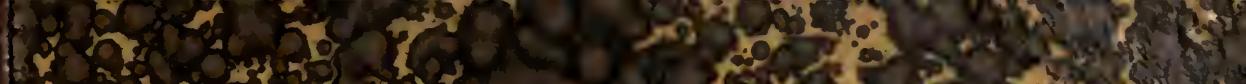

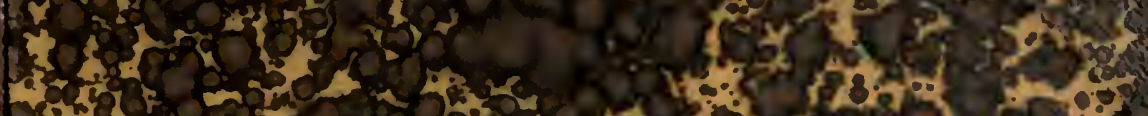
3. Hor

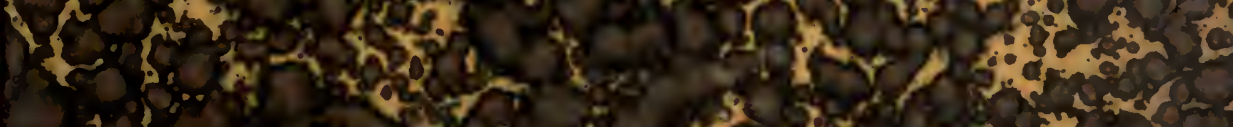

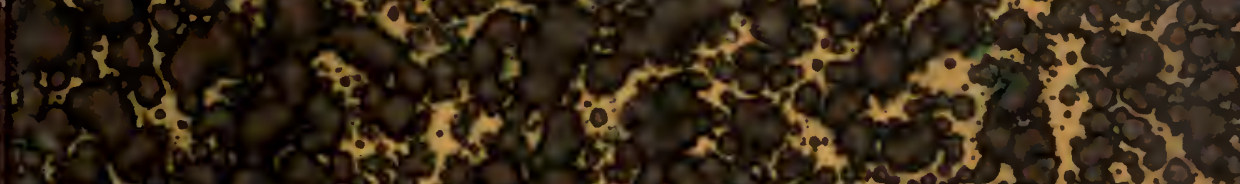

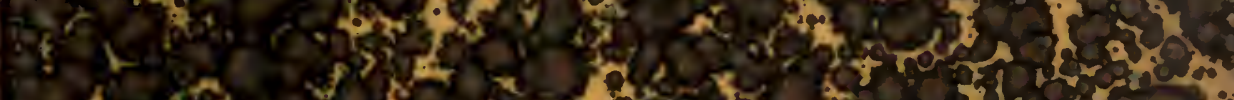

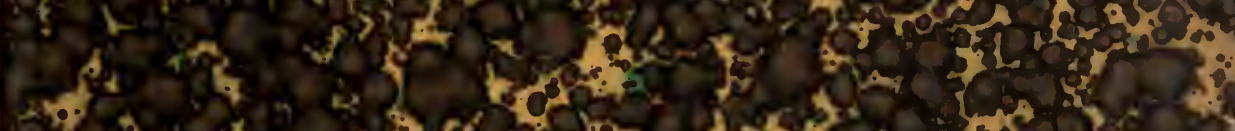

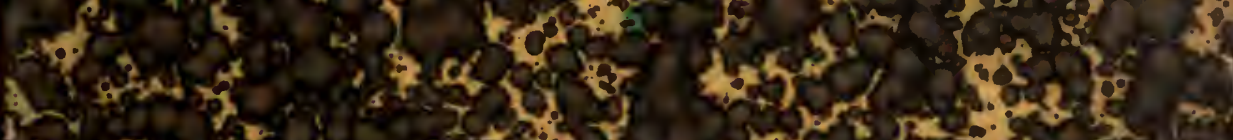

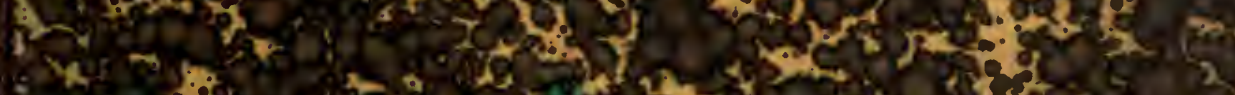

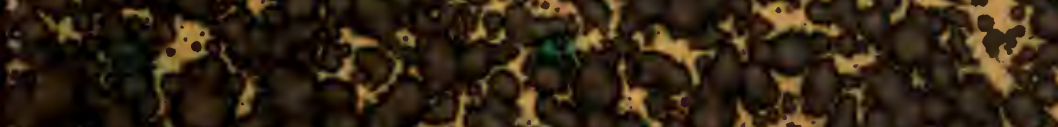

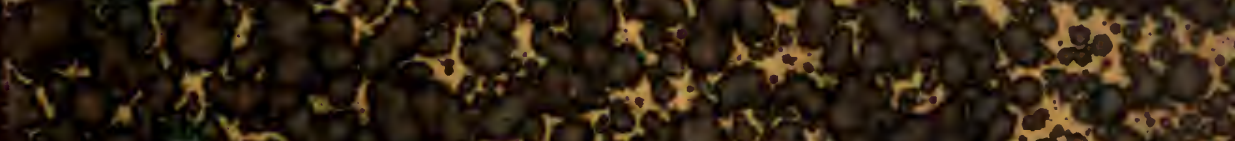

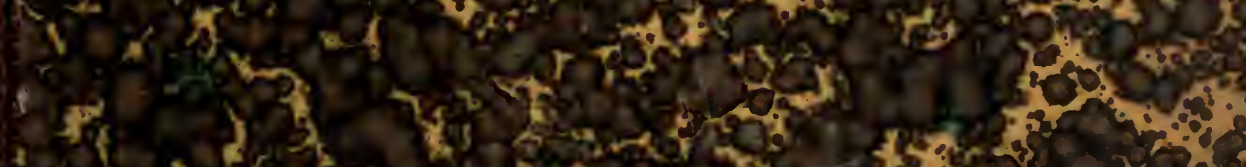

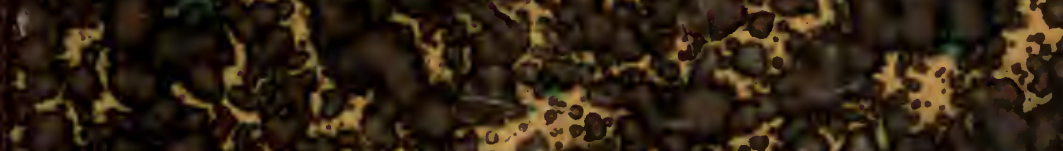
a the to

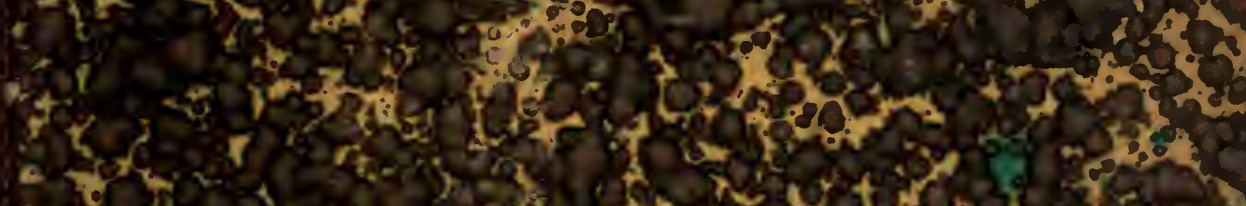

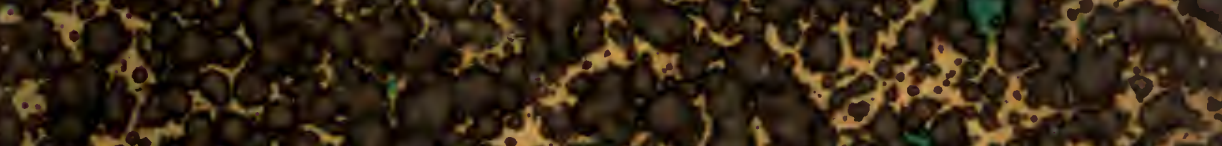
200 $70 x+2 \times 2$

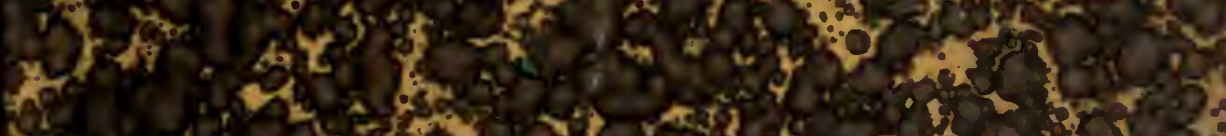

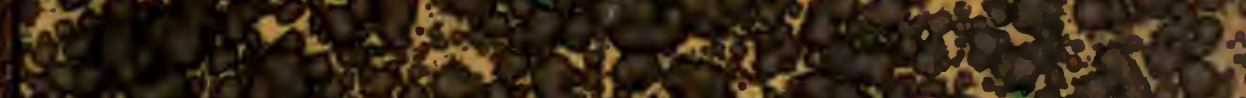

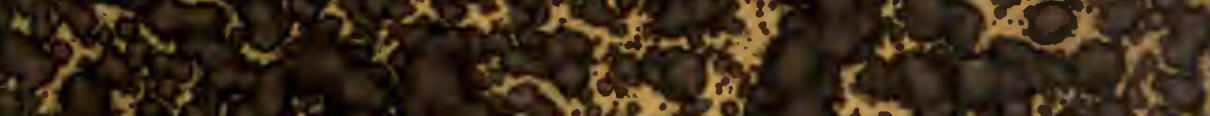

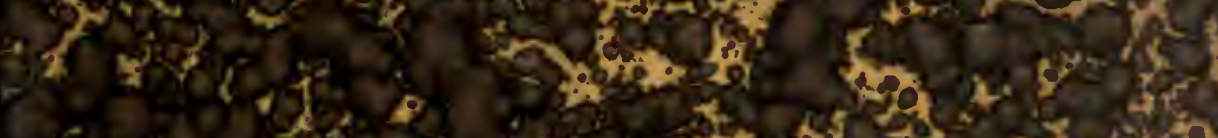

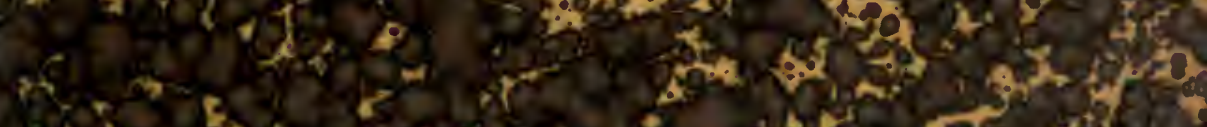
$470.52 \times$ C $^{3}$

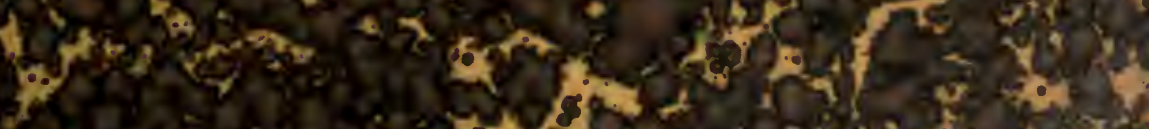

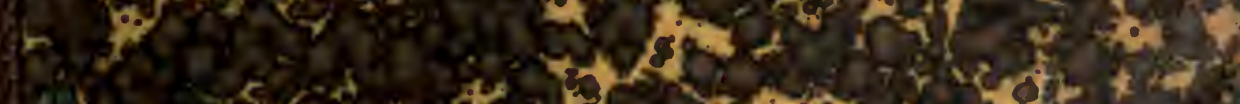

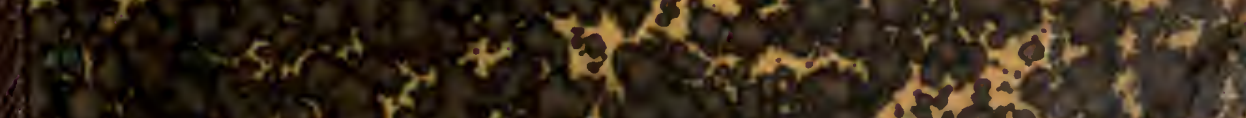

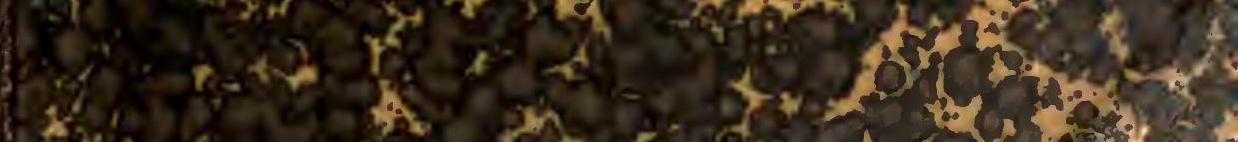
10 a 8 
$32,3=10$ 


- Treldiana 



Field Columbian Museum

Publication 65.

Zoological Series.

VOL. III, No. 6.

\section{A CONTRIBUTION}

TO THE

\section{ICHTHYOLOGY OF MEXICO.}

BY

Seth Eugene Meek,

Asssistant Curator of Department.

D. G. Elliot, F.R.S. E., Curator of Department.

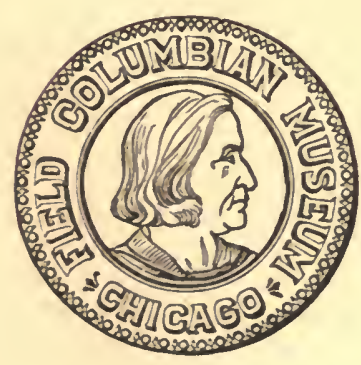

Ciircago, U. S. A. May, 1902. 



\title{
A CONTRIBUTION TO THE ICHTHYOLOGY OF MEXICO.
}

\author{
BY SETH EUGENE MEEK.
}

The following paper is based on a collection of fishes made in Mexico during April, May and June, Igor, by the writer and Mr. Frank Eugene Lutz, instructor in zoology in Chicago University, as volunteer assistant. The more important river systems were examined, chiefly with the view of discovering the southern range of our North American ichthyic fauna, and the northern range of the South and Central American faunas.

Most of the collecting was done with two $1 / 4$-inch mesh seines, one being 25 feet in length, the other about 50 feet.

The central portion of Mexico is a plateau ranging from about 3,500 feet above the sea to about 8 , ooo feet. The streams vary much in size; many go quite or entirely dry during the dry season, while during the rainy season they become torrents. Our visit was made during the latter part of the dry season when the streams were very low. The collection secured is perhaps larger than all other collections combined from the fresh waters of Mexico. The fish fauna of Mexico is very interesting. In the northern part of the country we find a few species not found elsewhere, while a large portion of the fauna are species, which have migrated south. The South American fauna predominates as far north as Mexico City, though a few of its forms extend into Texas.

In making this collection we would acknowledge the assistance of the following gentlemen: Mr. J. H. Hampson of the Cuernavaca \& Pacific Railroad, Mr. W. Morcom of the Mexican Southern Railroad, Mr. E. A. White of the Interoceanic Railroad, Mr. Chas. Sheldon of the Chihuahua \& Pacific Railroad, Mr. Jno. P. Ramsey of the Rio Grande, S. Madre and Pacific Railroad, Mr. H. R. Nickerson and Mr. T. R. Ryan of Mexican Central and to Mr. Ward, Superintendent of Wells, Fargo Express Co., and to the officials of the Atchison, Topeka \& Santa Fe Railroad. We also received considerable aid from station agents on these various railroads where we stopped and also 
from Mr. Woodsicle, custom agent for the Mexican Central Railroad at Cuidacl Juarez.

The following River systems were examined as listed below:

\section{The Casas Grandes System.}

The Rio Casas Grandes is a small mountain stream which Hows into Lago de Guzman. In the dry season the lake becomes nearly or entirely dry and there is very little water in the river below Terrasas. At Colonia Juarez, about i6 miles above Terrasas, the river the last of June contained little water, nearly all of which was taken out a short distance below into irrigating ditches. The fish life was abundant, but there were only a few species. The water was clear, and cooler than other similar mountain streams farther south. Where the water was confined in holes and not running it contained a large amount of algæ, enough to fill the meshes of our net and make hauling difficult. Lago de Guzman at the time of our visit was dry. A few fishes were taken from a small spring branch near the railroad station. It is probable that this river system was once a tributary of the Rio Grande.

\section{The Santa Maria System.}

The Rio Santa Maria runs parallel to the Rio Casas Grandes and empties into Lago de Santa Maria about ro miles sontheast of Guzman. These lalies are separated by a comparatively low ridge, but so high that their waters have not mingled with each other for a considerable time. I visited this water system only at Santa Maria. The lake was dry, but there were several large ponds fed by many large springs. These ponds were surrounded by a considerable amount of aquatic regetation. The bottoms were of loose mud or muck. The water in the springs and spring brooks was clear, and contained $C$. elegrans and $N$. lutrensis in abundance.

\section{The Carmen System.}

The Rio Carmen is a small river east of the Rio Santa Maria. It empties into Lago de Patos about 50 miles southeast of Lago de Santa Maria. It the time of my visit, June $2 \mathrm{I}$, the lake was dry except a few holes some 20 feet wide and 50 or 60 feet in length. These were reported to contain fish, but a half day's seining resulted in getting none. At the San Jose Ranch, some 
5 or 6 miles from the lake, is a large spring, and a spring branch whose waters are taken up by the sand within less than a mile from the spring. C. elegans is the only fish found here.

At Ahumada, 9 miles from the lake, all of the water in the river was taken out by irrigating ditches. A small collection of fishes was made in the largest irrigating ditch. It seems that on the approach of the dry season the fish in these small separate river basins migrate to the head waters. A large number are said to die in the lakes as these bodies of water become dry. The concentration of the salts in the water due to evaporation is no doubt the cause of the great mortality reported when the lake has been reduced to about one-fourth of its largest size. Mr. Jackson of Ahumada, who occasionally fishes for the market, informed me that in June no large fishes could be found short of about 20 miles up the river.

These three river systems were probably at one time a part of the Rio Grande System.

\section{The Conchos System.}

The Rio de los Conchos is one of the southern tributaries of the Rio Grande. We visited the Rio Chihuahua, a tributary of the Rio Conchos, at Chihuahua. The water was very low. This stream flows with a moderate current over sandy or gravelly bottoms. The water contained a large amount of algæ. This stream, where visited, was well shaded by large trees and bushes.

The Rio Santa Cruz at San Andres is a small stream with sandy and gravelly bottom: by the end of the dry season it contains but little running water. Our fishes were collected in a few holes in the bed of the stream just below the city. There is very little vegetation of any sort along this stream near San Andres. This same stream at Ortiz, a considerable distance below San Andres, was entirely dry.

The Rio Noavaco at Santa Rosalia contains considerable water throughout the dry season, though this is confined to long deep holes with but little running water between them.

At Jimenez the Rio Conchos was nearly dry. Our collections were made from a few deep holes about 2 miles below the city. These contained a large amount of aquatic vegetation, which made collecting difficult and unsatisfactory. The water was very clear, and in the deeper places were seen many large suckers which we were unable to capture. Sunfishes were very abundant. All of these streams become large and deep in the 
rainy season, at which time the Rio Conchos at Jimenez becomes 200 or more feet in width and as much as 15 feet in depth.

\section{The Lago de Castillos System.}

This lake receives the water from a large depression on the divide between the head waters of the Rio Conchos and the Rio Yaqui. Lago de Castillos is a large body of water in the wet season, but nearly all. of its water is evaporated by the end of the dry season. The seining of a few holes yielded but one species of fish. A few small fishes are reported in some of the springs on the margin of the lake bed even in the dry season. These are either the young of L. nigrescens, or are possibly Cyprinodon elegans and Notropis lutrensis, more likely all three of these. I was unable to visit any of these springs, as my time when I visited Bustillos was limited. The Bustillos hacienda comprises most all of this drainage area.

\section{The Rio Yaqui System.}

The Rio Paphigochic, a tributary of the Rio Yaqui, was visited at Miñaca. This river contained a small amount of running water. Its current was rapid and Howed over beds of sand and gravel. We collected in the deep holes and shallow places along the river for about a mile. The similarity of the fishes in this stream and the Rio Conchos is very striking.

The Tarahumares, a tribe of Indians living south of Miñaca, catch fishes by poisoning the water with some herb. This is reported to make the fish drunk. This is evidently a method similar to the one used by the Cherokee Indians in the Indian Territory. The Cherokees pound up the roots of the walnut and mix the juice with the water. I have never seen this operation, but from the description I have heard of it, it seems that the walnut juice in the water acts as an astringent on the gills of the fishes, no doubt causing a smothering sensation. The fishes become active for a while and often swim with force enough to land themselves high and dry. Later, if they remain in the water, they become stupefied and are easily caught. Mr. A. G. Maddren, who visited the Caroline Islands a few years ago, informed me that some herb there was pounded up and its juice mixed with the water to capture tide-pool fishes. It is interesting to note this method of taking fishes by natives in three such widely separated localities. 


\section{The Lerma System.}

The Rio Lerma is the longest river in Mexico. In its basin are found a large number of lakes. Some of these lakes, as Lago de Chapala, are still connected with the river, while many, as Patzcuaro, Zirahuen and others, have long since become isolated and at present each one forms an independent drainage system.

The Rio Verde was visited at Aguas Calientes. It contained but little running water. In the bed of the stream were a number of holes from three to five feet in depth. The water, though apparently clear, contained a large amount of algæ which so clogged the meshes of the seines as to make collecting difficult. The bottom was of sand and gravel.

A small stream, a tributary of the Rio Verde, flows through the city of Lagos. It contained but a small amount of water. There is a small lake about two miles from Lagos. It is about one-half mile in diameter, and is bordered by a rich growth of cat-tails, tules and other forms of aquatic vegetation. There were no sandy shores and it was quite impossible to use a seine in it.

In the lake, a small ditch near by, and in the stream at the city, a small collection of fishes was made. Cat-fish, probably Ameiurus dugesii, are reported common in the lake, but we were unable to obtain any.

At La Barca the Rio Lerma is a rather broad, deep river with a very sluggish current. The river was too deep to wade any distance from the shore, and so a few hauls of the seine were made from shore by means of ropes, and with better results than is usually accomplished in this way. The bottom and shores were muddy; occasionally along the margin was considerable aquatic vegetation.

Lago de Chapala is the largest fresh water lake in Mexico. The Rio Lerma flows into this lake near La Barca at the northeast corner, and flows from it a few miles farther down at Ocotlan. After the river leaves the lake it is known as the Rio Santiago.

At Ocotlan we collected in the main river and in a few small bayous. The river here is about 200 feet wide and to to 15 feet deep. Its banks were steep but less so than at La Barca.

La Palma is a small village some 20 miles from Ocotlan and on the opposite shore of the lake. Lago de Chapala is from ro to 25 miles wide and about 50 in length. It is surrounded by high hills and mountains. The lake, especially between Ocotlan and La Palma, is shallow. For a mile or so from La Palma it is not 
over 6 or 8 feet deep. At La Palma is a rich growth of cattails and tules. The bottom, a short distance from shore, is muddy. Our collection was made along shore, in and about the tules, and some distance out where the water was not deep. There is considerable fishing done here for the market. The cat-fishes Ameiurus dugesii are known as Bagre. Xystrosus popoche and Fulcula chapala are Sardinia. Algansea ruliescens is La Poache. The large Chirostoma are Blancas, and the small Chirostoma and the various species of Pacilida are known as Mojarra. The fishes caught here are marketed largely in Ocotlan.

It Celaya a small collection of fishes was made in a small stream which flows by the depot. In this stream was considerable vegetation.

The Rio Lerma at Acambaro is a clear stream not over 4 feet deep, flowing over a sandy bottom. It contained but few fishes at this place. A large irrigating ditch well filled with aquatic vegetation yielded a good number of Paciliida.

Lago de Quitzeo is a large shallow lake without any outlet. At Huingo, where our collection was made, the lake was not over 2 feet deep as much as one-eighth of a mile from the shore. At one-fourth of a mile it is less than 6 feet deep. There are a number of hot springs along the shore west of Huingo, and near the depot a small stream fed by a warm spring flows into the lake. This stream was alive with Paciliuda. Between the lake and the city of Huingo a large amount of salt is gotten each year, and so the lake is known as a salt lake, though its waters may perhaps be but little if any more saline than are the other lalies in this region which have no outlets. The small Paciliide are known here as Charral.

Lago de Patzcuaro is a beautiful sheet of water some ro miles long by 2 to 4 miles wide. It is surrounded on all sides by high mountains, and is perhaps the most beautiful and picturesque lake in the Lerma Basin. Its shores near the city of Patzcuaro are fringed with a rich growth of tules and other aquatic plants. About 3 miles from the landing is an island, and between it and the shore the lake loes not exceed a depth of 30 feet; beyond the island it is reported to be much deeper. A great deal of commercial fishing is done here. The larger fishes, Pescados Blancas, are marketed at Patzcuaro and Morelia. A few are sent to Uruapan and neighboring towns. The small fishes of all species are dried in the sun and marketed in that condition. The fishes are caught in long seines. Lago 
de Patzcuaro has no outlet, and its waters have become somewhat brackish.

Lago de Zirahuen is a small, deep mountain lake. Its drainage area is small, and the lake is abont one mile in diameter. A portion of its shore is sandy and muddy, while much is fringed with regetation. This lake also has no outlet. The fishes from it are very dark in color. In this respect they are much like the fishes in Lago de Chalco. Commercial fishing is carried on here to some extent.

\section{The Drainage System of the Valley of Mexico.}

Lago de Texcoco is a large shallow lake in the valley of Mexico. Its size varies much during the year. It is connected with all of the other lakes in this valley by canals which carry off much of the filth of the City of Mexico as well as of other cities near by.

Lago de Chalco is deeper and smaller than Texcoco. This lake supports an immense amount of vegetation. Not far from Tlahuac, in the bed of the lake, is a large spring. The water is about 20 feet deep, and can be seen boiling up through the sand on the bottom over an area of more than roo feet square. Our collections from this lake were made at Chalco and Tlahuac.

Lago de Xochomilcho is much like Lago de Chalco. The few fishes in our collection from this lake were purchased from fishermen in the markets of the City of Mexico.

\section{The Balsas System.}

The Rio Balsas is south of the Rio Lerma and is the second largest river wholly within Mexico. We visited this river at Balsas, a small village almost directly south of the City of Mexico. The river at close of the dry season, at this place, was about roo feet wide and ro to 5 feet deep. The mountains on either side rise almost from the water's edge, forming a sort of cañon. The current was very swift, while at intervals of a mile or so were rapids or cascades. In the bed of the stream are a few small bayous and cut-offs, and in these most of our fishes were collected. The Rio Balsas in the wet season is for a while one of the great rivers of this continent. Its water in the dry season is so brackish that the natives seldom use it.

The Rio Cuculo is a small stream tributary to the Rio Balsas at this place. It contained no running water. The few deep holes near its mouth furnished an excellent place to collect fishes. 
In the dry season the natives dig basins in the bed of this stream from which they get their drinking water.

The Rio Ixtla, a tributary of the Rio Amacusac which empties into the Balsas, is a clear stream with sandy and gravelly bottom. Our collections were taken from this stream a short distance above the picturesque old bridge at this place. A few specimens were also taken from the Rio Tembernbe, a small tributary of the Rio Ixtla.

\section{The San Francisco System.}

At La Antigua the Rio San Francisco is a broad stream with a hard bottom. At this point the water was not more than 4 feet deep. La Antigua is just above tide water, and most of the fishes taken here belong to salt or brackish water.

A tributary of the Rio San Francisco at Jalapa is a small stream. A dam is built at the head of the falls. Above the dam the water is deep and the stream fills the narrow valley, forming a sort of lake which is well filled with aquatic regetation. Seining here was quite impossible. A few fishes were taken above the dam by using the seine as a dip net.

The small stream below the dam was seined for some distance. It was narrow, with steep muddy banks, and contained a great deal of vegetation.

\section{The Panuca System.}

At San Juan del Rio we visited the Rio Moctezuma which flows into the Rio Panuca. The water in it was confined to a few deep holes, with none running between them. Collecting here was easy and satisfactory. The bed of the river was rocky, but the shore of the deep holes next the bed of the stream was sandy and with a gentle slope.

\section{The Verde System.}

The Rio Verde is a small Pacific coast stream which heads a short distance above Oaxaca. It was nearly dry when our collection was made. Its bed at Oaxaca is broad and covered with sand. A few holes in the bed contained a fer fishes belonging to two species.

\section{The Quiotepec System.}

The Rio Quiotepec drains a considerable area directly east of the head waters of the Rio Balsas, and flows into the Gulf of 
Mexico. At Cuicatlan near the close of the dry season the water in the river was rather shallow; in many places less than 4 feet deep. It flows with a swift current over a sandy and gravelly bottom. A small creek flows into the river near Cuicatlan. Our collection was taken from the main stream, the small creek and from a few cut-offs and bayous in the bed of the river.

The Rio Tehucan at Venta Salada is a rapid mountain stream. The rocky bottom and walls, and the swift current made collecting with a seine unsatisfactory. A few species, hoivever, were captured which proved to be especially interesting.

The following new genera are described in this paper: Zoogoneticus, Chapalichthys, Skiffia and Melaniris.

The following is a list of the new species described:

Rhamdia oaxaca
Catostomus conchos
Catostomus sonora
Algansca rubescens
Gila minaca
Aztecula mexicana
Votropis robustus
Votropis santarosalia
Ezarra tlahuacensis
Fundulus oaxaca
Zoogoneticus diazi
Zoogoneticus miniatus
Skiffa lerma

The measurements, scale and fin ray counts are made in the usual manner. The length of the body is measured from tip of upper jaw to base (last caudal vertebra) of caudal fin; the total length is measured from tip of jaws to tip of caudal rays; only fully developed rays are counted. The length of the head is measured from tip of upper jaw to poster edge of opercle; length of snout from its tip to anterior margin of orbit. Scales in the lateral series are counted to the base of caudal fin; transverse series from insertion of ventrals or anal, whichever is nearest middle of the body when the lateral line is present, and the count above includes the row on which the lateral line is found.

The following is a list of the places near which our collections were made. In order to abbreviate, the name of the city nearest which the species was taken is given instead of also giving name of stream and date; for example, "Colonia Juarez," after the name of a species, means that it was taken from the Rio Casas Grandes near the village of Colonia Juarez in the State of Chihuahua on June 26. 
Colonia Juare\%: Chilualuna, Mexico, Rio Casas Grandes, June 26.

Guzman: Chihuahua, Mexico, spring near railroad station, June 25.

Santa Maria: Chiluahua, Mexico, springs and ponds near clubhouse, June 24 .

San Jose: Chihuahua, Mexico, spring at San Jose ranch, Lago de Patǫs, was nearly (lry. $\mathrm{No}$ fish in the few porls left, June $2 \mathbf{I}$.

Ahumala: Chihuahua, Mexico. A large irrigating ditcl. No water in the Rio Carmen, June 22.

Chihuahua: Chihuahua, Mexico, tributary of the Rio Conchos, June 19.

Santa Rosalia: Chihuahua, Mexico, Rio Noavaco, June 10.

Jimenez: Chihuahua, Mexico, Rio Conchos, June 9.

San Andres: Chihuahua, Mexico, Rio Santa Cruz, June I7, 18.

Bustillos: Chihuahua, Mexico, Lago de Castillo, the lake was dry except a few small holes, June 14.

Miñaca: Chihuahna, Mexico, Paphigochic, June 16, 17.

Aguas Calientes: Aguas Calientes, Mexico, Rio Verde, June 7.

Lagos: Jalisco, Mexico, tributary of the Rio Verde, and small lake near the city, June 6.

La Barca: Jalisco, Mexico, Rio Lerma, June 5.

Ocotlan: Jalisco, Mexico, Rio Grande de Santiago and a few bayous, June 2 and 3 .

Celaya: Guanajuato, Mexico, small stream tributary to the Lema, May 28.

Ocambaro: Guanajuato, Nexico, Rio Lerma, Nay 27.

La Palma: Michoacan, Mexico, Lago de Chalco, May 30, 3 I.

Huingo: Michnacan, Mexico, Lago de Quitzeo, May 26.

Patzcuaro: Michoacan, Mexico, Lago de Patzcuaro, May 18 to 22.

Zirahuen: Nichoacan, Mexico, Lago de Zirahuen, May 24.

San Juan del Rio: Queretaro, Mexico, Rio Moctezuma, May 16.

Chalco: Nexico, Mexico, Lago de Chalco, April 30, May 1.

Texcoco: Mexico, Mexico, Lago de Texcoco, May I3.

Puente de Ixtla: Morelos, Mexico, Rio Ixtla, April $2+$ to 26.

Balsas: Guerrero, Mexico, Rio Balsas and Rio Cuculo, April 22 and 23.

Venta Salada: Puebla, Mexico, Rio Teluucan, May 6, I901.

Cuicatlan: ()axaca, Mexico, Rio Quiotepec, May 5, rool.

Oaxaca: Oaxaca, Mexico, Rio Verde, May $4,1001$.

Jalapa: Vera Cruz, Nexico, tributary of Rio San Francisco, May 9.

La Antigua: Vera Cruz, Nexico, Rio San Francisco, May 10.

\section{LEPISOSTEID E.}

Lepisosteus osseus (Linnarus).

Four specimens of this species were taken at Santa Rosalia.

$$
\text { SILURIDA. }
$$

Istalarius balsanus Jordan \& Snyder.

Bagre.

This species is quite common at the Balsas. Several large specimens were taken from the main river. The fontanelle was well developed in specimens over 2 feet in length. 
Several small specimens were also taken at Puente de Ixtla, the type locality. These specimens and the smaller ones táken at the Balsas are much darker on ventral side than are the larger specimens. The ventral surface of specimens 2 feet long is white. It does not shade into the bluish on sides, the line between the two colors being very marked. Puente de Ixtla; Balsas.

\section{Ameiurus pricei Rutter.}

Head $3 \frac{4}{5}$; depth 5; D-i, 6; A. I9. Body elongate; head rather narrow; lower jaw the shorter; premaxillary band of teeth truncate behind; interorbital width $2 \frac{1}{5}$ in head; eye small, 6 in head; barbels 8 , the maxillary ones reaching slightly beyond gill openings; pectoral spine smooth in front, serrate behind, serrations 5 (in specimens $2 \frac{1}{4}$ inches in length) to 8 (in specimens $6 \frac{1}{4}$ inches in length); pectoral spine $2 \frac{1}{2}$ in head, equals length of the dorsal spine; base of anal $2 \frac{2}{3}$ in its distance from snout, $1 \frac{1}{6}$ in head. Origin of dorsal nearer tip of snout than to origin of base of adipose fin. Caudal deeply forked. Bluish above, lighter below; a few dark spots on the body; lobes of caudal fin edged with black.

These specimens differ somewhat from the description of $A$. pricei. President'D. S. Jordan informs me that $A$. pricei was described from a few small specimens, and it is his opinion that our specimens from Miñaca are the same species. Very large cat-fishes are reported to be taken in the Yaqui. Miñaca.

\section{Ameiurus dugesii Bean.}

Abundant in Lago de Chapala. Specimens were taken by me at La Barca, Ocotlan and La Palma. None were seen at Patzcuaro, Zirahuen and Huingo, and I was told by the fishermen that there were no cat-fishes in these lakes. They are reported as common in the Lerma at Morelia and Acambaro, but in the dry season are found only in the deepest holes. Ocotlan; La Barca; La Palma.

I here give a key by which the two species of Ameiurus now known from the Pacific slope may be recognized:

a. Pectoral spine without serrations (or a few weak ones in the young). Dorsal spine long, $I_{3}^{2}$ to $I_{6}^{5}$ in the lengtl of the head.

DUC:ESI1.

aa. Pectoral spine strongly serrate; dorsal spine short, $2 \frac{1}{4}$ to 3 in the length of the head; anal rays 18 to 23 . PRIcis. 
Leptops olivaris (Rafinesque).

One specimen 5.80 inches long from the Rio Noavaco.

Large cat-fishes are reported to have been taken from the Rio Conchos at Santa Rosalia.

Rhamdia oaxacæ, sp. nov.

Type, No. 37 r 7 , F. C. M. Length, $5 \frac{7}{8}$ inches.

Locality, Rio Quiotepec, Cuicatlan, Oaxaca, Mexico.

Head $3 \frac{3}{4}$; depth $5 \frac{1}{3}$; D. i-6; A. ro; gill-rakers $3+7$. Body slender; head large, upper jaw slightly the longer; top of head flat, narrow forward: eye small, $6 \frac{1}{4}$ in head; snout $2 \frac{3}{4}$ in head; occipital process $4 \frac{1}{2}$ in head; fontanelle reaching middle of orbit; profile from nostrils to origin of dorsal straight; maxillary barbels reaching nearly to middle of base of adipose fin, slightly shorter in largest specimens ( $6 \frac{3}{4}$ inches in length); mental barbel reaching $\frac{3}{5}$ distance to pectoral; post-mental to just past base of pectoral; dorsal fin slightly higher than long, its base about $1 \frac{4}{5}$ in head: dorsal spine weak, flexible, $\mathrm{r} \frac{1}{2}$ in lase of fin: distance from tip of snont to dorsal fin $2 \frac{1}{4}$ in length of body; adipose fin well developed, its origin at tips of dorsal rays when the fin is deflexed; base of adipose fin $2 \frac{4}{5}$ to 3 in length of body. Least depth of caudal peduncle $2 \frac{1}{2}$ in head; pectoral spine strong, with small teeth on its outer margin, the larger two or three being near its tip; inner margin of pectoral serrated, except the portion near the tip opposite the two or three large teeth near tip on front; pectoral spine, 23 in head: ventrals situated behind base of last dorsal ray; caudal forked, its lower lobe broad and round, its upper pointed, with rounded tip. Color uniform, dull olivaceous, slightly lighter on lower half of body. A narrow dark band along lateral line. Dorsal fin with a light cross band occupying the second fourth of fin from base. No dark dots on body.

This species differs from $R$. wagnerii in having a shorter head and no black spots on the body. Cuicatlan.

\section{CATOSTOMIDE.}

\section{Carpiodes tumidus Baird \& Girard.}

Head $3 \frac{1}{2}$ in the length of the body: depth, $2 \frac{4}{5}$ to $3 \frac{1}{5}$. Dorsal rays 24 to 26 ; the anterior rays short; their tip, when fin is depressed, reaching to about two-thirds the distance from base 
of anterior rays to base of posterior. Tip of dorsal fin rounded; scales $7-38$ to $4 \mathrm{I}-6$.

Color light brownish, silvery below; the middle of each scale silvery, forming indistinct silvery lines along the rows of scales. Longest specimen ro 1/4 inches in length. Santa Rosalia; Jimenez.

\section{Pantosteus plebius (Baird \& Girard).}

This species is very variable. The dorsal fin usually has 9 rays, occasionally xo, seldom xx. Scales in the lateral line range from 85 to roo.

A study of a large series from Colonia Juarez, Miñaca and San Andres indicates that but one species of Pantosteus exists in this region. Colonia Juarez; Ahumada; San Andres; Miñaca.

Catostomus sonorensis, sp. nov.

Type, No. 3564, F. C. M. Length, $5 \frac{5}{8}$ inches.

Locality, Rio Paphigochic, Miñaca, Chihuahua, Mexico.

Head 4; depth 413; D. xii; A. 7; scales II-65-1o. Body robust; profile very convex; top of head flattish, broad, interorbital $2 \frac{1}{2}$ in head; snout blunt, $2 \frac{1}{2}$ in head; eye large, $4 \frac{1}{2}$ in head; lips thick, papillose; papillæ in eight or nine rows on upper lip. The two halves of upper lip meet at a very obtuse angle. Dorsal fin as high as long, its base $x_{5}^{2}$ in length of head, its margin slightly concave. The tips of first rays reaching middle of last ray when the fin is deflexed; tips of last dorsal rays opposite tips of ventrals, which reach to vent; pectoral $1 \frac{1}{3}$ in head; ventrals $I_{5}^{2}$.

Origin of dorsal fin slightly nearer base of caudal than tip of snout; caudal deeply emarginate, lobes equal; scales small on anterior half of body.

Color steel blue to brownish, white below. Young specimens have the dark lateral blotches.

This species differs from Catostomus bernardini in having larger scales. Miñaca.

\section{Catostomus conchos, sp. nov.}

Type, No. 3557 , F. C. M. Length, ro.64 inches.

Locality, Rio Conchos, Jimenez, Chihuahua, Mexico.

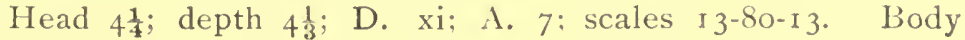
robust, terete, not much compressed, except posterior third; snout blunt, its length $2 \frac{1}{3}$ in head: lips thick, papillose, about 
nine rows of papillæe on upper jaw; lower lip broad, deeply incised, the two halves posteriorly forming an obtuse angle; hinder margin of upper lip fringed with papillæ; base of third dorsal ray midway between tip of snout and base of caudal; about 45 scales in a series from nape to first dorsal ray; scales below lateral line near middle of the body are smaller than those above this line.

Profile convex: interorbital convex, $2 \frac{1}{4}$ in head; pectoral fin $I_{3}^{1}$ in head, the tips not reaching ventrals; ventrals $I_{5}^{3}$ in head; distance from tip of ventrals to vent $3 \frac{3}{4}$ in ventral fin; dorsal fin longer than high, its height $I_{3}^{2}$ in head, length of base $I_{2} \frac{1}{2}$ in head; the tip of last dorsal ray scarcely reaching opposite tips of ventrals when fin is deflexed.

Color, light steel blue on back, shading into a dark olive on sides; lighter below, especially on posterior half of body, where the line between the light and dark color is very marked. On anterior half of body the colors gradually merge into one another.

Eight small specimens also from Jimenez. The small specimens $2 \frac{1}{4}$ inches in length are more robust and have a larger eye than the type; the tips of pectorals reach anal fin.

Sides with three large dark blotches resembling those on the young of Catostomus commersonii. Dorsal fin also higher in the young, longest ray about $\frac{1}{6}$ in head, tip of first ray reaching nearly to tips of last when fin is deflexed. In the larger specimen the first rays reach but a short distance beyond base of last ray. Jimenez.

Moxostoma congestum (Baird \& Girard).

A few small specimens from Santa Rosalia I identify as this species.

\section{Moxostoma austrinum Bean.}

A few specimens were seen at La Palma and Ocotlan. All were taken in Lago de Chalco. One specimen 9 inches in length gives the following measurements:

Head $4 \frac{4}{5}$; depth 4 ; distance from dorsal to snout $2 \frac{1}{4}$ in length of body; eye $4 \frac{2}{3}$ in the length of the head; snout $2 \frac{1}{2}$ : base of dorsal $1 \frac{2}{5}$ : longest dorsal ray $1 \frac{1}{5}$; pectoral $\mathrm{I}$; ventral $1 \frac{2}{5}$; caudal peduncle $2 \frac{1}{10}$; scales $48-18$. This specimen has a shorter head and smaller scales than those of fishes of this species, formerly described. A few large specimens were seen at La Palma. Ocotlan; La Palma. 
CYPRINID质.

Campostoma ornatum Girard.

Eggs in females from Chihuahua not much developed, not enough to give any definite idea as to time of spawning season. All of the specimens of this species were collected during the last half of June.

Very abundant in Northern Mexico, in the head waters of the Atlantic and Pacific coast streams.

Taken by me as follows: Colonia Juarez; Chihuahua; San Andres: Santa Rosalia: Jimenez: Miñaca.

\section{Hybognathus melanops (Girard).}

Head 4 : depth $3 \frac{1}{3}$; Eye equals snout, $3 \frac{1}{2}$ in head. Scales 4 I to 45 . Origin of dorsal slightly nearer base of caudal than tip of snout. Dark brown color. edges of scales darker, forming longitudinal lines along rows of scales. The entire body covered with minute dark dots. A dark lateral band ending in a black caudal spot: this is indistinct in the larger and darker specimens. Largest specimen 2.50 inches. Ovaries slightly developed. Spawning season about August. Abundant. Chihuahua; jimenez.

Algansea tincella (Cuv. \& V'al).

This is a very variable species. Those from the lakes about the City of Mexico are very robust and have a rather short caudal fin. The gill-rakers are very short, $3+12$. The scales range from 65 to 70 . Specimens from San Juan del Rio are rather slender and have a longer and more pointed caudal fin. In this respect these specimens are not unlike those from Celaya, and Aguas Calientes. In all of these the gill-rakers are short and not more than 15 in number. Vertebræ $20+17=37$.

The black caudal spot is well defined in the smallest specimens from all of the localities, though on individuals about $\delta$ inches in . length from Lago de Chalco it is undistinct or absent.

Drs. Jordan and Evermann regard $A$. australe as a synonym of A. sallei. I do not believe this is correct. The latter species belongs to a river basin which lias a different fauna. The specimens described by Dr. Jordan are not in good condition. Mr. Bean, who kindly re-examined the types of $A$. australe, believes it had more than 60 scales in the lateral line. Dr. Gunther's locality for $A$. sallei may be wrong. 
Algansea dugesi Bean is perhaps a valid species. It differs from $A$. tincella in having more gill-rakers. None of the specimens in our collection can be referred to this species. Dr. Bean gives the number of gill-rakers as $t+15$. The dorsal fin is inserted slightly before the ventrals in $A$, dugesi and over them in $A$. tincella.

Ovaries well developed; spawning time about middle of May to early in June.

The natives on Lago de Chalco bake this fish in corn husks to sell at the trains and in the markets.

This species seidom exceeds 8 inches in length. Aguas Calientes: Lagos: Celaya; Acambaro: San Juan del Rio: Chalco: Texcoco.

\section{Algansea rubescens, sp. nov.}

Type, No: 3653 , F. C. M. Length, 6 inches.

Locality, Rio Santiago. Ocotlan, Jalisco, Mexico.

Head 4: depth 4: D. 8: A. 7: scales 16-65-10. Body elongate, rather robust: snout bluntish, $4 \frac{1}{3}$ in head; mouth oblique, lower jaw shorter, included: maxillary scarcely reaching eye, $3 \frac{1}{4}$ in head: caudal peduncle large, its least depth 2 in head: 33 scales before the dorsal, the origin of the latter slightly nearer the base of caudal than tip of snout: lateral line complete. decurved. Color olivaceous with a reddish tinge on sides, silvery below, a black spot at base of caudal fin. No markings on other fins.

Ovary well developed. spawning time probably about the middle or last of June. Longest specimen, 6 inches.

This species differs from $A$. tincella in the larger and more numerous gill-rakers. It differs from A. lacustris in having much lareer scales. Ocotlan.

\section{Algansea lacustris Steindachner.}

This species is characterized by its small scales, there being from 85 to 94 in the lateral series. and from 30 to 36 in transverse series. The gill-rakers are long and slender, the number being $5+17$. This species is much lighter in color than the others of the genus. Dr. Steindachner describes a second species of this genus from Lago de Patzcuaro. A. larascorum, which differs from A. lacustris in having much larger scales, about 76 in the lateral line. An examination of the figures of these two species shows each to have about 90 scales in the lateral line.

I examined a large number of Algansea taken by the fishermen 
at Patzcuaro and was unable to detect more than one species. Eighteen specimens in our collection show considerable variation. I am inclined to believe that the two species described by Dr. Steindachner are the same. Spawning time the last of May or early in June. Patzcuaro.

KEY TO THE SPECIES OF ALGANSEA.

a. Scales large, ferter than $5^{6}$ in the lateral series. SALLEI.

aa. Scales smaller, more than 60 in the lateral series.

b. Gill-rakers short and blunt, I 5 to I9.

c. Gill-rakers 3+ I 2; dorsal fin inserted over ventrals.

T'INCELLA. rals.

cc. Gill-rakers 4+I5; dorsal fin inserted slightly before ventI) UGESI.

bb. Gill-rakers longer and slender, 22 or 23 on first gill arch.

d. Scales larger, $6_{5}$ in the lateral series.

RCBESCENS.

dd. Scales small, 85 to $9+$ in the lateral line.

L.ACLSTRIS.

\section{Pimephales confertus Girard.}

Length of largest specimens 2.76 in.

This species is quite abundant in Northern Mexico. It is even more variable than its northern relative, Pimephales promelas.

On the upper half of the body of small specimens (less than 2 inches in length) are narrow vertical (slightly inclined backward) dark streaks, which are usually much branched. These also appear on larger specimens. but in much smaller numbers.

A few of the males from Santa Rosalia are almost black. These hare a light vertical bar on shoulder crossing base of pectoral fin. and a second bar on middle of body crossing base of ventral fin. Pectorals black: ventrals and anal black, edged with white. The caudal fin is light with a broad black bar across its middle: on lighter colored males the fins are less dark, and there are no cross bars on sides of body.

Many of the males have tubercles on the end of the snout. This species is more chubby than Pimephales promelas; it also has smaller scales, $5^{2}$ to 55 in the lateral line, instead of +3 to 47 . There is some difference in the markings on the males. The lighter males and females have a dark lateral band which does not end in a dark caudal spot. This band is more distinct on smaller specimens. Usually the anterior portion is partially concealed with a dash of red: under side of head and breast with some red. Longest specimen, 2.76 inches in lengti. 
Specimens in our collection are from the following localities: Colonia Juarez: Santa Maria; Guzman; Chihuahua; San Indres: Santa Rosalia: Jimenez; Miñaca.

Gila minaca, sp. nov.

Type. No. 3573 , F. C. M. Length, 4.46 inches.

Locality, Miñaca. Rio Paphigochic, Miñaca, Chihuahua, Mexico.

Head $3 \frac{4}{5}$; depth $4 \frac{2}{5}$; D. 9; A. 8; scales 24-90-I I. Body elongate, back not arched; snout bluntish: month terminal, rather large, maxillary reaching anterior margin of pupil, its length $36^{1}$ in the head; snout $3 \frac{1}{2}$; eye $4 \frac{1}{4}$; body completely scaled; origin of dorsal shightly behind origin of ventrals, midway between base of caudal and anterior margin of orbit; base of dorsal 2 in head, its longest ray $I \frac{1}{4}$ in the head; the tips of all of the dorsal rays together when the fin is deflexed, and fall opposite to the middle of base of anal fin: tips of pectorals reaching $\frac{2}{3}$ distance to ventrals, length $I \frac{1}{2}$ in head; tips of ventrals reaching to vent, length $I_{3}^{2}$ in head; caudal fin forked, the upper lobe the larger: lateral line complete, decurved, its lowest part over space between tip of pectorals and ventral fins, reaching axis of body on posterior half of caudal peduncle. A row of pores from nostril to nape, a second row from nostril forward a short distance, then curving downward and backward under eye near upper angle of opercle: candal peduncle very slender, nearly terete, its least depth $3 \frac{1}{2}$ in the length of the head.

Color, light olivaceous, a faint dark band from base of cauclal to opposite first dorsal rays; fins all plain: a very faint caudal spot.

This species resembles $G$. elegans, from which it differs in the, shorter anal and pectorals, the more rolust caudal peduncle, absence of hump before the dorsal fin, and the longer head.

This or another species of Gila is found in the Carmen River system. Miñacá.

\section{Lenciscus nigrescens (Girard).}

This species is very abundant in Northern Mexico. It is very variable. Scales in the lateral line vary from 66 to 75. The larger specimens (9 to I i inches in length) are of a uniform dark color and without the black lateral band. In smaller individuals ( 2 to 4 inches in length) the color is lighter and the dark lateral band is very prominent and ends in a rather indistinct spot at base of the caudal fin. Specimens from Chihuahua, Santa Maria, 
Colonia Juarez and San Andres are rather darker than those from Miñaca.

Lago de Castillos at Bustillos was dry, but a few specimens were taken from two small ponds near by. Although but a few feet apart the fishes from one were very dark while the others were much lighter than any taken elsewhere.

Lago de Patos at San Jose was nearly dry. Fishes were reported to be in a few holes in the bed of the lake, but a reasonable amount of seining did not procure any specimens. None were taken from a large ditch at Ahumada, some ten miles above the lake.

Mr. Jackson, an American at Ahumada, informed me that there were suckers and two species of other fishes, similar to fishes found in the Gila River, in the River Carmen, some twenty miles above thumada. One had the caudal peduncle much more slender than in the other; one was probably this species, the other a Gila, probably the same species found in the Rio Paphigochic, a tributary of the Rio Yaqui at Miñaca.

Specimens of this species are in our collection as follows: Colonia Juarez; Santa Maria; Chihuahua; Bustillos; San Andres; Miñaca. At all these places it was very abundant. It reaches a length of about 12 inches.

This species is distributed throughout the larger part of the Rio Grande and adjoining river basins. None were taken at Jimenez and Santa Rosalia.

Aztecula Jordan \& Evermann.

The three species of this group have a very robust body and much smaller scales than the species of Votropis, to which they seem to be more nearly related.

\section{Aztecula mexicana,"sp. nov.}

Type, No. 3606, F. C. M. Length, $2 \frac{7}{x}$ inches.

Locality, Rio Moctezuma, San Juan del Rio, Qutertaro, Mexico.

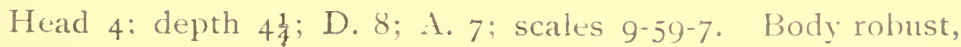
back slightly elevated, its highest point over pectoral fin and some distance in advance of the dorsal: snout blunt; mouth terminal, oblique, lower jaw the shorter: eye small, its diameter $4 \frac{1}{2}$ in the head; iris silvery: snout 4 in head: interorbital area 3 in head. Origin of dorsal fin midway between base of canclal and the eye, 3 I scales in a series before dorsil fin: 
caudal peduncle slender, its least depth $2 \frac{1}{4}$ in the head; pectorals short, their tips reaching about half way to base of ventrals, I 3 in head: ventrals nearly reaching vent, 2 in head.

Lateral line decurved and wavy, complete or missing on a few scales only.

Color, dark olive above, lighter below: a faint lateral band most conspicuous on last half of body: a faint caudal spot, which is. more prominent in the young.

This species differs from Astecula asteca in the smaller scales, and more slender pedincle and the larger eye.

Eggs well developed, spawning season about June ist. Abundant at San Juan del Rio. Not taken elsewhere.

\section{Aztecula azteca (INoolmani)}

A few specimens were taken from a small elitch by the side of the Interoceanic Railroad, near Texcoco Lake. These specimens agree with the description given by Woolman. A few were also taken in Lago de Chalco.

it present three species of this group are known: one, Aztecula asteca. from the Valley of Mexico; one, Aztecula mexicana, from Rio Noctezuma, a tributary of the Rio Panuca; and one, Aztecula lerme. from Lake Lerma, near the head waters of the Lerma river. Texcoco.

Notropis robustus, sp. nov.

Type, No. 3548, F. C. M. Length, $2 .+6$ inches.

Locality, Rio Conchos, Jimenez. Chihnahua, Mexico.

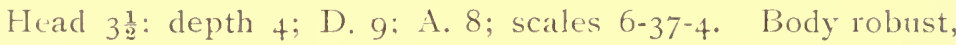
back little arched, its highest point being just in front of dorsal fin: snout blunt; mouth nearly terminal, slightly oblique, large; maxillary $3 \frac{1}{4}$ in the head, its tip reaching vertical from pupil.

Lateral line slightly decurved, complete; eye large, its diameter $3: \frac{1}{2}$ in the head: interorbital space 3 in head.

Pectoral fins long, nearly reaching ventrals, $I \frac{1}{2}$ in head: ventrals 2 in head. Origin of dorsal midway between base of caudal and nostril, 15 scales in a series before dorsal fin: caudal peduncle slender. its least depth $2 \frac{1}{4}$ in head.

Color olivaceous, a dark lateral band from snout to base of candal, which ends in a small spot at base of middle caudal rays; chin white.

This species resembles Notropis llennius, from which it differs in having a larger head, a broader and more robust body, 
the prominent lateral band and the black spot on base of middle caudal rays. Santa Rosalia; Jimenez.

Notropis calientis Jordan \& Snyder.

Abundant at Aguas Calientes; a few specimens were also taken near Ocotlan, and at Acambaro. Most of the specimens from Iguas Calientes are covered with parasites. Ovaries well developed in the females from Aguas Calientes, indicating a close approach to the spawning season. These specimens, were taken June 7. Largest specimens $2 \frac{1}{4}$ inches in length. Aguas Calientes: Ocotlan: Acambaro.

Notropis nigrotæniatus Gunther.

This species is very abundant at Puente de Ixtla and Balsas. It was first taken by Boucard at Atlisco, in the head waters of one of the northern tributaries of the Balsas River. The types are reported to be 4 inches in length. Of a large number taken by us the longest is but 3 inches in length, the average length being $2 \frac{2}{3}$ inches. This is the only species of this genus found south of the City of Mexico. It is our most southern cyprinoid. No species of the genus Notropis is found in the United States west of the great divide, and so it seems rather strange that the most southern range of this large group of fishes should be in a Pacific coast stream.

Eggs quite well developed, evidently approaching the spawning season. Our specimens were collected about the $22 \mathrm{~d}$ to 26 th of April. Spawning season probably in May. Balsas; Puente de Ixtla.

\section{Notropis chihuahua Woolman.}

This is one of the best marked species in the genus. At present it is known only from the upper portion of the Conchos River system, where it is abundant. Eggs well developed, apparently near the spawning season. Longest specimens, 2.50 inches. Chihuahua; San Andres; Santa Rosalia; Jimenez.

Notropis ornatus (Girard).

This species is found on both sides of the divide. Specimens from Miñaca average smaller than those from Chihuahua, the longest from the former place being 2.30 inches, the longest from the latter being 2.55 inches in length.

The smaller specimens show only traces of the dark vertical 
bars on sides and a more prominent dark caudal spot than those of the same size from Chihuahua.

I tew of the larye males from Minaca are black. a white ver rical band on preopercle behind eye: the fins are all black with narrow white margins: a vertical white bar on base of caudal fin.

The variation in color of the specimens from Miñaca is much greater than in those from Chihuahua. Specimens from other localities ate like those from Chihuahua. Ont specimen from san Indres. Mbundant at the other places. Egss well dereloped. evidenty near the spawning season. Chihuahua: San Indres: Jimenez: Miñaca.

Notropis lutrensis Baird a Girard.

This is the most abundant minnow in northern Mexico. It occurs on both sides of the divide. Many of the specimens trom Jimenez. Santa Rosalia and San Andres are highly colored. those from lhumada are very pale. This species is very variabit. The young are more slender than the adults. scales in series betore dorsal i6 to 19 . in the lat ral line 3 ?

Evermann and Goldsborough identify a small specimen from santa Maria as hitrefis frisidu. I am inclined to britert that the specimen is the young o this species. It is too badiy mutilated ti adnit of positite identification.

The lateral line of this species varies. It is complete on most ot the specimens tound in the Conchos basin. thayn wecasionally it is absent on a tew scales on caudal peduncit. It is less complete in specimen: from santa Maria. The paitst specimens are front the two last named regions. The lateral line when not complete usually rezches to the posterior part a the anal tin. We find no specimens in our collection which stem to

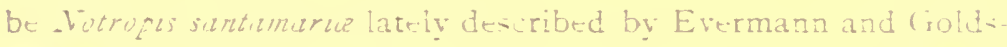
borough. Egr- well developed: evidently this fpecits -pawn. early in Junt. sinta Maria: Ihumada: Chihuahua: Cansa Rosalia: Jimintz: San tnires: Miraca.

Notropis formosus (Girard.

This species is very abrindant at Colonial Juared. It much resembles . $b$. lutrems. Lut has snaller scales. scain in the lateral line +2 to +9 . Usually ++ . Scalt: betore dorsal. z + . Latral line complete except occasionally absent on a t-w scales. This specits does not stem to intererade with. 1 . lutrense though no drube it is at late ott-shoot ot that species.

This specirs spawns tarly in Junt. Colonia. Juart\%. 
Notropis santarosaliz, sp. nov.

Type, No. 3535 , F. C. M. Length, I.92 inches.

Locality: Rio Nonava, Santa Rosalia, Chihuahua, Mexico.

Head 4 : depth $t_{3}^{1}$ : D. 8: A. ro; scales 6-37-3. Body elongate, rather slender: snout pointed; mouth, large terminal, oblique: jaws about equal, end of maxillary reaching to middle of the pupil, margin of upper lip on level with center of eye: eve large. 3 in head: snout + .

Origin of dorsal fin midway between base of caudal and anterior margin of orbit. 18 scales in a series before dorsal fin: base of dorsal fin $2 \frac{1}{3}$ in head, its longest ray $\mathrm{I} \frac{1}{2}$ in head: pectorals $\mathrm{I} \frac{1}{3}$ in head: ventrals I $\frac{f}{5}$ : lateral line decurved. complete. The lateral line runs about one scale below the lateral band. Color light olivaceous, with a broad dark lateral band from snout through eve to base of caudal. The band is more prominent on the posterior half of the body. It does not end in a black caudal spot: fins all plain.

This species belongs to the rubrifrons type. It differs from $\checkmark$. rutirifrons in the shorter snout, more forward position of dorsal fin, and in the prominent dark lateral band. Taken only at Santa Rosalia.

Xystrosus popoche Jordan \& Snyder.

Common at both Ocotlan and La Palma.

Falcula chapalæ Jordan \& Snyder.

Common in Lago de Chapala. La Barca: Ocotian: La Palma

Evarra tlahuacensis, sp. nov.

Type, No. 36si. F. C. M. Length. 2.35 inches.

Locality: Chalco Lake, Tlahuac, Mexico, Mexico.

Head $t$ : D. $5 \frac{1}{2}$ : D. S: A. I 4 ; scales 95 : eye equals snout. $3 \frac{2}{3}$ in head: upper jaw protractile; teeth $t_{-}+$tips hooked, grinding surface fairly well developed.

Body elongate. rather slender: snout blunt: mouth little oblique: tip of maxillary reaching anterior margin of orbit: diameter of the eye equals the length of the snout. $3 \frac{3}{3}$ in the length at the head: upper jaw protractile: gill membranes connected ti isthmus: peritoneum black: the length of the alimentary canas equals distance from eye to tip of caudal tin.

Origin of dorsal midway between base of caudal and punt rior margin of eye: about 3 sc scales in a series betore dorsil tin. 
lateral line complete, decurved above pectorals; first dorsal ray reaching beyond tip of the last ray when the fin is deflexed.

Color, dark olive, white below, the line between the colors distinct and extending from below eye to one-quarter distance from rentral surface of caudal peduncle. A dark vertebral and a dark lateral hand. This species differs from Eíarra eigenmanni in having smaller scales, a higher and longer anal fin, a more posterior dorsal fin and a more slender body. Tlahuac, Lake Chalco.

\section{Evarra eigenmanni Vioolman.}

I few small specimens of this species were taken in Lake Chalco at Tlahuac.

Hybopsis altus (Jordan).

This species is usually found in clear rumning water. It reaches a length of about 5 inches. Aguas Calientes: Lagos: Celaya: Acambaro.

\section{Rhinichthys simus Garman.}

Head 35 : depth 5:3: 1). 9: 1 . 8 : scales 60: snout 23 in the length of the head: eye small, 5 in head: origin of dorsal fin midway between base of caudal and anterior nostril: lateral line straight, complete: snout long, somewhat depressed, mouth inferior.

Color lightit olivaceous, a dark lateral band, no silvery one; a small dark caudal spot. Longest specimen 2.32 inches. I few specimens taken at Santa Rosalia.

\section{CHIRACINIDAE}

Tetragonopterus argentatus (Baird d (iirard).

Anal rays ig to 21 . This species is very abundant in the head waters of the Rio Conchos. Largest specimens nearly + inches in length. Ovaries not dereloped enough to give one any definite idea of the spawning time.

Chihuahua: Santa Rosalia: Jimene\%.

Tetragonopterus mexicanus Filippi.

This species was first noticed by lilippi in 1853 , and is reported by him from the City of Mexico. This species, or rather this genus. does not occur in the lakes about the City of 
Mexico, or in the Lerma Basin. It is quite probable that Filippi's specimens came from some stream east of.Mexico City.

Dr. Bocourt in Annales des Sciences Nat., I862, gives a short account of several supposed new species of Tetragonopterus which evidently do not exist. The number of anal rays of this species varies from 20 to 23 . It is perhaps a little less slender than $T$. argentatus, though the large series of specimens before me rather suggests that this and the preceding species are the same. In color and size both species are alike.

The stomach of one specimen from Cuicatlan contained a good-sized /teterandia. All of the specimens we have from the southern rivers of Mexico belong to one species.

This species seldom exceeds 4 inches in length. Abundant; our specimens from Puente de Ixtla; Balsas; Cuicatlan; Venta Salada.

\section{DOROSOMATIDAE.}

Dorosoma mexicanum (Gunther).

Two small specimens from La Antigua.

ENGRAULIDÆ.

\section{Stolephorus mitchilli (C. \& V.)}

Two small specimens from La Antigua.

\section{PCEILIID五.}

I was very fortunate in collecting the representatives of this family in Mexico during the breeding season. It was rather surprising to find so many of them viviparous. The fact that the anal fin of the male of many of the species of this family is not modified into a long slender intromittent organ, such as we find in Gambusia, Heterandia and the like, was regarded as sufficient evidence that they were not viviparous.

The shortening of the first half dozen rays of the anal fin in the male and their slight separation from the rest of the fin by a notch was first noticed by Dr. Gunther in Characodon lateralis. It was also described by Dr. Bean in Zoogoneticus robustus, and by Jordan and Sinyder in Goodea caliente. Dr. Bean supposed it to be characteristic of the female. This peculiar modification of the anal fin of the male exists in several genera of viviparous cyprinodonts.

Evermann and Goldshorough, in a recent paper on Mexican fishes call attention to the fact that Girardinichthys immoninalus is vivipar- 
ous. Either all of their specimens were females or they overlooked this peculiar modification of the anal fin of the male. The spawning time of all the specie's of this family in Mexico is near the close of the dry season.

Mr. Monkhaus informs me that he las taken young from the females of several species of Cyprinodonts in Brazil. It is quite certain that viviparity is far more characteristic of this family than has been generally supposed.

I append here a key to the genera of Pacilide. It is practically the one given by Jordan and Evermann in "Eishes of North and Middle America," though revised to include the new genera proposed in this paper.

KEY TO THE GEAERA OF P(ECILIH)A.

a. Intestinal canal comparatively short, little convoluted. usually less than one and one-half times the total length of the body ( 2 in Chapalichthis): teeth little movable: dentary bones firmly united. Species chiefly carnivorous.

b. Outer series of teeth enlarged, pointed or a few of the anterior ones compressed, incisor like: none of them notched, bicuspid or tricuspid.

c. Anal fin of the male similar to that of the female, not modified by having its five or six anterior rays short and stiff, and separated at their tip from rest of the fin by a notch, and not modified into a sword shaped intromittent organ. Species oviparous.

d. Tentral fins wanting: pharyngeal bones both above and below greatly enlarged. bearing coarse blunt teeth: scales normal. (Orestiina).

EMIPETRICITHYS.

dd. Ventral fins well dereloped: pharyngeal bones and teeth not enlarged. (Fundulina.)

e. Texth in more than one series, usually a larger outer series, behind which is a band of smaller teeth.

$f$. Air bladder well dereloped (in all species examined): no candal ocellus: body oblong: dorsal fin various in size and insertion.

Fixitus.

1f. Air bladker wanting: a black ocellus at root of caudal (at least in the males).

RIVILL'S.

ic. Teeth arranged in a single series: lorsal fin inserted in adrance of anal, its rays 9 to I 3 .

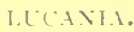

ci. Anal fin of the male with its first five or six rays short and stiff, and slightly separated from the rest of the fin by a notch. Species viriparous, the young usually of larece size at birth. 
- s. Dorsal and anal fin each of less than IS rays: body elongate, not much compressed.

ZOOGONETICLS.

gs. "Dorsal and anal fins each of 19 or more rays; body compressed.

GIRARDINICHTHYS.

bb. Outer series of teeth incisor like, bicuspid or tricuspid. (Cyprinodontinæ).

h. Onter series of teeth bicuspid with a band of villiform teeth behind them.

i. Intestinal canal about $I \frac{1}{2}$ in total length of body; the teeth very firmly attachd.

CHARACONON.

$z^{\prime}{ }^{\prime}$. Intestinal canal about 2 in total length of body; teeth less firmly attached.

CHAPALICHTHY:S.

hh. Outer series of teeth tricuspid, no villiform teeth behind them.

i. Dorsal fin short, of Io to 12 rays, the first ray slender and rudimentary.

ii. Dorsal fin long, of 16 to is rays. the first developed as a stout grooved spine. JORDANEI,LA.

ccc. Anal fin of the males placed well forward and modified into a sword shaped intromittent organ: teeth all pointed, arranged in bands. Species viviparous, the young of large size at birth. (Gambusinæ.)

$j$ Eye normal, the pupil not divided by a partition: dorsal fin inserted more or less behind the front of the anal.

k. Jaws not produced into a beak: lower jaw prominent, longer than the upper. The male much smaller than the female.

l. Dorsal fin long, of I4 to I6 rays; anal short.

PSELDOXIPHOPHORLS.

1l. Dorsal fin short. of 6 to 10 rays: anal short. Gimpl'sid.

$k k$. Jaws produced into a moderate beak; dorsal and anal short, each of 9 to I I rays.

BELONES()X.

jj. Eyedivided into two portions by a horizontal cross partition: vertical fins short, of 9 to I I rays.

A.IAISEPS.

aa. Intestinal canal elongate, usually coiled on ventral and right side, with numerous convolutions: dentary bones loosely joined: teeth movabie. Species chiefly mud eating.

$m$. Outer series of teeth bicuspid, with villiform teeth behind them: anal fin of the male with first five or six rays of anai fin short and stiff and separated from the rest of the fin by a notch. Species viviparous, the young of large size when born. (Goodeina.)

n. Body robust, oblong, depth 3 to + in length of body; gill- 
rakers long and slender. 35 to 40 on the first gill-arch. Vertebrat $19+17=36$.

(ion)lit.

nn. Body deep, compressed, depth $2 \frac{2}{3}$ to $3 \frac{1}{4}$ in length. Gillrakers rather short, stiff, abont 20 the first gill-arch. Vertebra $16+18=34$.

SKIFFIA.

$m m$. Onter series of teeth pointed: anal fin of the male placed well forward and modified into an intromittent organ. Species riviparous. (Pcecelina.)

o. Teeth in a single series.

p. Dorsal fin inserted in advance of the anal. PLATrpecilus.

$f p$. Dorsal fin inserted more or less behind the front of the anal.

oo. Teeth in more than one series.

HETERANIIA.

$r$. Dorsal fin inserted more or less behind the front of the anal; both fins small; dorsal 9 , anal 7 .

LEPISTES.

$r$. Dorsal fin inserted over or in advance of anal. its rays much elerated in the male.

s. Dorsal fin short of less than 7 to 1 i rays.

t. Teeth of inner series in both jaws trifid.

EROPRECH,L'S.

11. Teeth of the inner series in both jaws entire.

PECII.IA.

ss. Dorsal fin long, of 12 to 16 rays.

u. Caudal fin normal, alike in both sexes, or with the lower angle merely sharp in the male.

MIIIIIEXISIA.

uu. Caudal fin in the males with its lower lolu much produced and sword shaped.

XIPIIOPHORL's.

\section{Fl'NDLLLS Lacèpéde.}

This genus does not have many representatives in Mexico. It is probable that some of the species found in Southwestern 'Texas. especially those species which are peculiar to the lower Rio Grande lasin, extend their range into Mexico.

In this genus the anal fin of the males is like that of the females. Teeth firm and in more than one series. The alimentary canal is less than 1.2 times the length of the body. Species all oviparous.

Fundulus oaxacæ, sp. nov.

Type, No. 372 I, F. C. M. Lenesth, 2.25 inches.

Locality, Rio Verde, Oaxaca, Oaxaca, Nexico.

Head $3 \frac{1}{2}$ : depth $3 \frac{3}{1}$ : D. 14 : I. I5; Scales 30-I I. Body robust, profile from nape slightly concare: top of head broad, slightly convex: eve small. $4^{\frac{1}{2}}$ in head: snout not much depressed, 3 in head: interorbital space $2 \frac{1}{3}$ : lower jaw slightly the longer; teeth pointerl, in a band in both jaws. the outer series the 
larger; peritoneum black; alimentary canal shorter than the total length of the fish; origin of dorsal slightly in advance of anal, midway between tip of caudal and posterior márgin of the orbit: base of dorsal $2 \frac{1}{3}$ in head, its height slightly more than half head: pectoral ${ }_{6}^{5}$ in head: ventral $2 \frac{1}{2}$; caudal fin subtruncate.

Brownish olive. a dark spot in the middle of each scale. These spots are more prominent on the posterior half of the body of males which are from $I \frac{1}{2}$ to $I_{\frac{3}{4}}$ inches in length. In these males there is usually a row of spots on base of dorsal and anal fins. Young specimens have a few faint dark cross bars on the sides, which, in the larger females. become a faint dark lateral band.

Largest specimens, 2.46 inches in length. This species resembles Fundulus punctutus, from which it differs in having a larger head, a more robust body, the more forward position of the dorsal fin, and larger scales. It is evidently a smaller fish. The larger specimens have no spots on dorsal and anal fins. The type of Fundulus punctatus was taken at Chiapas, Guatemala.

Oriparous; eggs quite mature, Ioo eggs in a female 2.05 inches in length; diameter of eggs $\frac{1}{20}$ of an inch. Our specimens were collected May 4 .

Time of spawning, about the third week in May. Oaxaca.

\section{ZOOGONE'TICUS, gen. nov.}

Type, Pacilia quitseocnsis B. A. Bean.

This genus has the general appearance of Fundulus, differing in the modification of the reproductive organs. The anal of the male has the first 5 or 6 rays short and stiff. The ovary is a strong membranous sack with several fold-like partitions. In this the young are hatched, and reach a comparatively large size, after which they are then born.

The body is usually deeper than in Fundulus, and the anal and dorsal fins are usually longer. The dorsal fin of the male is considerably higher than that of the female.

\section{Zoogoneticus quitzeoensis (B. A. Bean).}

This species was first known from a female collected in Lake Quitzeo by Mr. Nelson, and described ly Mr. B. A. Wean. It has a short intestine, the length being $1 \frac{1}{4}$ times total length of the fish. The teeth are conical and in more than one series. the dentition being that of Fundulus. 
The females are lighter in color than the males; on the middle of the sicle of female to the tip of the pectoral are usually three faint dark spots, also four to six clark bars on lower half of caudal peduncle, and a dark spot on upper portion of caudal peduncle above the last bar. The color of the males is more uniform and much darker; the spots or bars so conspicuous on the female are scarcely noticeable on the male; dorsal and anal fins l)lack, tipped with yellow; candal and tips of ventrais blackish: pectorals light, as are all the fins of the female. The first six rays of anal short, and separated from the rest of the fin by a shallow notch.

The body of this fish is more compressed and less robust than that of others of this group. Head $3 \frac{3}{4}$ : depth 3 : dorsal rays I3 or 14: anal I3 to I5. This species is viviparous. Their young had evidently been born a short time previous to our visit.

They apparently deposit their young during the first half of May. La Barca: Ocotlan.

\section{Zoogoneticus dugesii (Bean).}

Intestinal canal about equal to length of body. Peritoneum blackish.

A few specimens were taken at Patzcuaro and a few at Lagros. Viviparous; one female from Patzcuaro 2.22 inches in lenerth contained 32 young: all were well formed and with egg absorbed; length of young. 6 inch. These are by far smaller than the young from females of other species.

No males were taken. The longest specimen is from Lagos, 2.50 inches. This well marked species is apparently very scarce.

Patzcuaro specimens taken May i 8 to 22 : time for spawning evidently last half of May. Lagros: Patzcuaro.

\section{Zoogoneticus robustus (liean).}

This is one of the largest Cyprinodonts found in Mexico. It is known only from the Lerma liasin.

The largest specimen in our collection is a female 6. So inches in length. It was taken in Lake Zirahuen on May 24.

The color of the few specimens from this lake is rery dark. The species is viviparous. One female from Patzcuaro Lake. 4.26 inches in length, contained 20 young, each .67 inch in length. These young possess the markings of the smallest specimens collected.

A sccond female from Patzcuaro Lake, +.65 inches in length, 
contained $3^{8}$ well developed young, each .75 inch in length. The young taken from a single fish are very uniform in size. These specimens were collected May ig to $2 \mathrm{r}$. The specimens taken from Lake Chapala, May 3 I to June 2, had all spawned out. Spawning time for this species is second and third weeks in May.

Alimentary canal scarcely as long as the body; peritoneum grayish: origin of dorsal fin midway between base of caudal and anterior margin of opercle. The young of this species much resembles the young of Goodea atripinnis, the small spots being smaller and more pale. A good sized Gambusia infans was taken from the stomach of one of the fishes taken in Ocotlan. Ocotlan; Patzcuaro: Zirahuen.

Zoogoneticus diazi, sp. nov.

Type, No. 36r 8, F. C. M. Length, 2.60 inches.

Locality, Lago de Patzcuaro, Patzcuaro, Michoacan, Mexico.

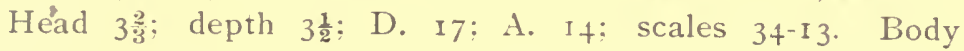
elongate, robust, more compressed than in 2 . robustus; back much elevated, forming a prominent angle at the nape; top of head slightly convex; interorbital width $2 \frac{1}{2}$ in head; snout bluntish: mouth large, lower jaw the longer; chin very prominent; snout + in head; eye moderate, its diameter $3 \frac{1}{2}$ in the head. Dorsal fin slightly in advance of the anal, its origin midway between base of caudal and posterior margin of opercle.

Base of dorsal $I_{6}^{5}$ in the head, its height 2 (in male $I_{\frac{2}{5}}^{2}$ ) in head: anterior dorsal ray short, the anterior rays gradually increasing in length to the eighth or ninth. which is the longest. Pectoral fin $1 \frac{2}{5}$ in the head: ventral $2 \frac{3}{5}$.

Alimentary canal scarcely as long as the body; peritoneum light; teeth in a band in each jaw, all of them conical, the outer series being the larger.

Light olivaceous, much mottled with darker, which forms irregular cross bars on the sides; many of the larger specimens in life with a reddish tinge over the body, which fades to nearly a uniform light olive: fins all plain. The males are a little duller and of a more uniform color than are the females. Largest specimen, a female 3.60 inches in length. The few males obtained average smaller than the females.

This species is close to $\%$. robustus. It differs from that species in having larger scales, a less advanced and longer dorsal fin. The coloration is also much different and the flesh less firm. 
Viviparous; One female 3 inches in length contained 28 young, each about .60 inch in length; another female 3.15 inches in length contained +7 young, each .43 inch in length; egg all absorbed. Specimens collected May rg to 24. Spawning season about the last of May or early in June. Named for Porfirio Diaz, l'resident of the Republic of Mexico. Patzcuaro: Zirahuen.

\section{Zoogoneticus miniatus, sp. nor.}

Type, No. 3680, F. C. M. Length, 1.60 inches.

Locality, Lago de Chalco, near Chalco, Mexico, Mexico.

Head 3!: depth 31: D. 17: A. 14: scales 32-14. Body elongate, compressed: mouth rather large. very protractile, lower jaw slightly the longer: teeth conical, very large, in a band; eye $2 \frac{2}{3}$ : snout $+\frac{1}{2}$ : interorbitals 3 ; pectorals short and broad, 13 in head: ventrals 3 ; origin of dorsal fin midway between base of caudal and middle of preopercle, and slightly in advance of origin of anal.

Intestinal canal short, about as long as body; anal fin modified, the first 7 rays short, the other 7 long, and the two groups of rays separated by a shallow notch.

Olivaceous, much mottled with darker. No distinct lateral band. The last bloteh forms an indistinct black caudal spot. In general color and form this fish very closely resembles. Skiffia ariegata. Largest specimen (Type) 1.60 inches long.

Total number of specimens 5, in rather poor condition. Chalco.

This genus includes the following species:

Zoogoncticus quitzinensis (J). A. Bean). Lago de Quitzeo; La Barca: Ocotlan.

Zoogoneticus dugresii (Jean). Cimanajuato: Lagos: Patzcuaro. Zoogoneticus rohustus (Bean). Guanajuato: Ocotlan: Patzcuaro: Zirahuen.

Zoogoneticus sruatemalensis (Gunther). Lake of Duenas: Lake Amatitlan: Rio Guacalate, V'estern Ecuador.

Zoogoneticus pachycephalus (Gunther). Lake Atitlan.

Zoogoneticus latialis (Gunther). Rio San Geronimo: Guatemala: Yzabal.

Zoogoneticus diasi Meek. P'atzcuaro; Zirahuen.

lougoneticus miniatus Meek. Chalco. 
Girardinichthys innominatum Bleeker.

Body rather deep, somewhat compressed, the gravid females being particularly deep. Origin of dorsal fin in male midway between base of caudal and middle of opercle, and slightly in advance of origin of anal fin. Anal fin of male modified by having the first 6 rays about $\frac{1}{2}$ or $\frac{2}{3}$ the length of the next rays, and separated from them by a small notch. In this respect they are like Characodon, Goodea, etc. Teeth strong, in a band rather than in a single series, the dentition being much the same as that of Fundulus. Peritoneum spotted, not wholly black. Intestinal canal pressed to left side, not coiled. about the length of body: vertebra $16+21=37$. Gill-rakers short and stiff, 15 on first gillarch.

On fishes less than $\mathrm{I}_{\frac{3}{4}}$ inches in length there is a black spot between vent and anal fins. and usually a black spot on belly just at base of pectorals. On some small males these spots run together. Evermann and Goldsborough describe these spots on specimens large and small from Lago de Lerma. The dorsal and caudal fins of males very black: ventrals also black; caudal dusky. Some of the males are almost entirely black. Cross bars are prominent on all the larger specimens; in small specimens these gradually shade out to short lateral blotches, In general the specimens from Lago de Texcoco are much lighter in color than are those from Lago de Chalco.

Viviparous; a medium sized female from Chalco, quite plump. $2.2+$ inches long contained in the ovary 36 fishes. These were well developed, slaty blue, but not speckled, each about . 56 inch in length, except one, which, though well developed, was only +o inch in length. The young were closely crowded together and bent over each other in all sorts of shapes. The egg-yolk still persisted as a slender string attached to the abdomen. A female from 'Texcoco, 2.19 inches long, contained 52 tmbryos. each .55 inches in length. A large female from the same place, 2.69 inches long, contained 240 (white and slender) young. Male fish somewhat smaller than females.

The viviparity of this species was noticed in a recent paper by Evermann and Goldsborough. The peculiar modification of the anal of the male was orerlooked, or all of their specimens were females. Viviparity is no doubt much more common in species of this family than was formerly supposed. Chalco: Texcoco: Xochnmilcho. 


\section{CHARACODON Gunther.}

This genus is characterized by having firmly fixed bicuspict teeth, and a short intestine which is from I to I times the total length of the fish. Anal fin with first 5 or 6 rays short and stiff. Species riviparous. The type of this genus is $C$. lateralis, from Central America. It is described as having the first rays of anal of male short and stiff. Origin of dorsal fin almost over origin of anal. It is a little in advance in lateralis and rariatus, and slightly behind in furcidens. Vertebra in variatus $\mathrm{I}+\mathrm{I} 8=32$.

This genus now includes three species found in Mexico and Central America.

C. lateralis Gunther, from Central America,

C. a'triatus Bean. from Central Mexico, and

C. furcidens Jordan and Gilbert, from Lower California. The modification of the anal fin of the male in the last named has not been noticed, and we are not sure that it exists.

\section{Characodon variatus Bean.}

The male of this species has a distinct dark lateral hand. The tips of the rentrals are usually black. and the dorsal and anal fins have yellow margins.

Onc male. 2.67 inches in length, from Ocotlan, is much lighter in color than the others: sides with black spots as large as eye. In general the coloration of this specimen is more like that of the female than the male: the caudal is not black with a yellow margin. The lateral band is broken up into a row of spots; below this on caudal peduncle is a second row of similar spots.

The lateral band of the adult female is more or less broken. the color more variegated, while the lower half of the caudal peduncle has several distinct dark spots irregularly arranged. The young are much spotted, resembling $\%$. robustus. except that the spots are larger and less numerous. Specimens from Huingo are lighter than those from the other localities.

The largest specimen of this species in our collection is a male from Agnas Calientes, 3.15 inches in length: longest temale. 2.85 inches, was taken at Lagos.

The alimentary canal varies considerably; in some specimens, being scarcely longer than total length of the body, in others, $1 \frac{1}{2}$ total length. Peritoneum blackish.

Viviparous; one female 2.20 inche's in length, taken at Celaya on May 28 , contained i y young, well developed, show- 
ing markings of quarter grown specimens; length of young 55 inch. I second female 2.50 inches in length, from the same place, contained 23 young, each .46 inch in length.

A female 2.70 inches in length, taken at Aguas Calientes, June 7. contained 37 young, each . 40 inch in length.

Some of the females from Huingo collected May 26, are gravid. Aguas Calientes: Lagos: Celaya: Ocotlan; Huingo.

\section{CHAPALICHTHYS, gen. nov.}

Type. Characodon encaustus Jordan \& Snyder.

Body rather deep, compressed; caudal peduncle long and slender. About three-fourths of the dorsal fin in front of the anal; origin of dorsal midway between base of caudal and anterior margin of orbit; anal fin of male with first 5 or 6 rays shorter and separated from the other rays by a shallow notch; teeth in two series; the outer enlarged, bicuspid and firmly attached; the inner series small, and in small patches.

Alimentary canal elongate, convolute, or irregularly in three coils on the right side, its length nearly twice the total length of the fish: peritoneum black; caudal fin truncate.

This genus has the long alimentary canal of Goodea and the firm bicuspid teeth of Characolon. The dorsal fin is considerably more advanced in this genus than in either Goodea or Characodon.

Gill-rakers long and slender, 24; vertebræ $18+19=37$.

Chapalichthys encaustus (Jordan \& Snyder).

The dorsal fin of the male is higher than that of the female; longest dorsal ray of male $I_{10}^{\frac{1}{10}}$ in head. of female $1 \frac{1}{4}$ in head. Anal fin of male with its first rays short and stiff.

Longest female 3.50 inches; longest male 2.70 inches. The number of females greater in our collections than are the males.

Viviparons; one female 2.70 inches in length, contained 2 I young: size of young very uniform, each .40 inch in length. Egg not entirely absorbed. La Barca; Ocotlan: La Palma.

Cyprinodon elegans Girard.

A comparison of a large series of specimens from Northern Mexico shows considerable variation in color and fin markings. IIales from Chihuahua have a very pale dorsal: those from Miñaca. Jimenez and Santa Rosalia have the dorsal light, with some dusky on the base or on last rays. Males from Guzman 
and Santa Maria have a dark dorsal fin, bnt in many specimens the outer anterior half is very light. In the darker males. from all places, all of the fins except the dorsal are margined with black, the broader margins being on caudal and last anal rays. I agree with $\mathrm{Mr}$. Garman in uniting $C$. cximius with $C$. elegans.

The females have a black spot on middle of the last dorsal rays. This species spawns during the first half of July.

Very abundant in Northern Mexico. Colonia Juarez: Guzman: Santa Maria: San Jose: Ahumada: Chihuahua: San Indres: Miñaca: Santa Rosalia; Jimenez.

\section{Pseudoxiphophorus bimaculatus (Heckel).}

This species has the general appearance of Gambusir. It has a larger dorsal and the less advanced position of the anal fin than do species of Gumbusiz. It also reaches a larger size.

The largest female is 3.20 inches in length. The largest male is 2.24 inches in length. Is in Gambusia, the males are reported to be much less numerous than the females. They are much smaller and much less liable to be captured than are the females. so that the proportion of males to females found in collections is no true indication of that which really exists.

Peritoneum blackish: intestine short, shorter than the length of the fish: teeth conical, curved backward and in broad bands in each jaw. those on the lower jaw being the larger: lower jaw the longer.

Viviparous: one female 2.xi inches in length contained 48 eggs, each about ${ }_{1 \frac{1}{6}}^{1}$ inch in diameter, 42 of which had the eye spots formed. 6 showed no cye spots. These specimens were taken May 9. The time of depositing their young is probably near the first to the middle of June.

This species was very abundant at Jalapa, where it was found with viphophorus jalape. Jalapá.

\section{(i. IMISLSI.1 Poey.}

So far as known this genus is represented in Mexico by three species, $G$. affinis from the Rio Grande Basin, $G$. infans from the Lerma Basin, and $G$. gracilis, found in streams on both sides of the divide south of Mexico City.

Gambusia affinis (Baird \& (iirard).

A faint brownish band on sides: dorsal and especially the anal fin with much black, the anal being clarker on the distal half. 
One female specimen I.9I inches in length contained 30 eggs in which the eyes and outline of young were formed.

A second female from Jimenez, I.90 inches in length, contained 25 similar eggs, diameter of eggs $\frac{1}{1 \frac{1}{2}}$ of an inch. Abundant. Jimenez: Chihuahua; Santa Rosalia; San Andres.

Gambusia infans Woolman.

This species is much like G. affinis. It has a shorter head and larger scales, and is usually a little darker in color. Alimentary canal $\mathrm{I} \frac{1}{4}$ times the total length of the body: peritoneum black. One female from Ocotlan contained 15 large eggs in which the eyes and outline of the body were formed. A female 1.85 inches in length from Huingo contained I9 large eggs in which the eyes and outline of body of young were formed, $3+$ eggs not at all hatched, each ${ }_{15}^{1}$ inch in diameter, and 12 very small eggs, each about ${ }_{3}^{1}$ inch in diameter.

The specimens from Huingo are lighter in color than those from Ocotlan. A few small males were taken at Huingo, these are black, with the tip of the caudal yellow. Two males were taken at Celaya; one of these is black, and the other one has the color of the females. Length of males 1.05 inches.

Specimens from Huingo were taken May 26: from Celaya, May 28. and from Ocotlan June 2 and 3. The spawning time for this species is evidently about the middle of June.

The origin of the dorsal fin in the female of this species is well behind that of the anal. This is the cnly Gumbusia so far known from Central Mexico. It has been found only in the Lerma Basin. Celaya: La Barca: Ocotlan: Huingo.

\section{Gambusia gracilis Heckel.}

This species is very different from $G$. infuns and $G$. affinis. It has a dark lateral band made up of short irregular cross bars. The dorsal fin is also more posterior than in the other two species. With some doubt I identify our specimens with $G$. gracilis, which was originally described from Orizaba, Mexico.

One female, 1.66 inches in length, from Balsas, contained 3 I young. each coiled around the egg, 21 eggs in which,eye spots were present, 15 large eggs without eye spots, and $\delta$ small eggs. The large eggs are about ${ }_{1 ;}^{1}$ inch in diameter. This specimen was collected April 22. Spawning time evidently early in May. The males are 1.19 inches in length. being much smaller than the female. Taken by us at Balsas and at Puente de Ixtla. 


\section{KEY TO THE MEALAN SHECIES OF ( ANMBLSHA.}

a. Body without a dark lateral band made up of short vertical bars: origin of dorsal fin over midsle of anal, and slightly nearer base of caudal than base of pectoral fin.

b. Scales in the lateral line 30 ; head $3 \frac{1}{4}$ to 33 in the length of the body.

AFFISIS.

bh. Scales in the lateral line 26 : head $+\frac{1}{5}$ in the length of the body.

INITIS.

aa. Body with a dark lateral band, made up of short vertical bars: origin of dorsal behind origin of anal fin, its origin midway between base of caudal and middle of pectoral fin; scales 29 .

(;RACIIIS.

\section{GOOI)EA Jordan.}

The genus Goodea was proposed by Jordan in 1879 . It was based on $G$. atripinnis, a Fundulus-like fish taken from a salt lake in a volcanic basin near Guanajuato, Mexico. The teeth were erroneously described as tricuspid. In Igoo Jordan and Snyder proposed the genus Venendmm to include the Fundulus-like species with long intestines and bicuspid teeth. It my request Mr. B. A. Bean re-examined the dentition of the types of Goolca atrifinnis and found the teeth were bicuspid. He also kindly sent one of the cotypes to the Field Columbian Museum. In all of the specimens the teeth are decidedly bicuspid. The genus Xencumm therefore becomes a symonym of Gooder. Gill-rakers long and slender, 37 to to on the first gill-arch. Verteloriv $19+17=36$. Outer series of teeth bicuspid; behind these are villiform teeth.

Goodea caliente (Jordan \& Snyder).

This species appears to be very widely distributed, being fonnd over a large portion of the Lerma Basin, as well as in the Rio Noctezuma. a river which empties its water into the Atlantic. It inhabits the rivers and smaller lakes.

The specimens from Lake Quitzeo are very light in color, a feature clatacteristic of all the fishes taken from this and Patzcuaro Lake. Specimens from other places are quite dark, especially is this true of those taken from the streams.

The color of the male is more mniform than that of the female. The young are speckled with brownish, much rusembling the young of loogoneticus rolustus and the young of Charocodon i'ariatus.

The dorsal of the male is considerably higher than that of the 
female. Peritoneum.black, intestinal canal elongate, coiled on ventral and right side, its length three times the total length of the body. Mr. Bean kindly sent me one of the types of Goodea atripinnis. It is more slender than the specimens of this species in our collection. A study of the material in hand leads me to believe that all specimens listed below belong to one species.

Huingo, longest specimen 3.20 inches in length, average

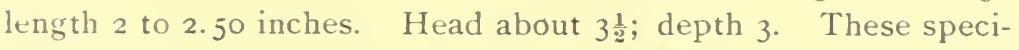
mens are very light in color; collected May 26, had evidently spawned a short time previously.. Gill-rakers 37 on first gillarch; vertebre $17+19=36$. Viviparous.

Celaya, a few gravid females collected May 28 .

Acambaro, females all spawned. Collected May 27.

Lagos, females all spawned. Collected June 6.

San Juan del Rio. one female 3.50 inches in length contained t4 young. each .53 inch in length, evidently near spawning time. Collected May i6.

Aguas Calientes, females spawned. Collected June 7. Gillrakers 38 . vertebra $19+17=36$.

Goodea luitpoldi (Steindachner).

In general appearance this species resembles a Fundulus. It reaches a length of 7.75 inches, and is perhaps the largest Mexican species of the family to which it belongs.

I have compared a large series of specimens from Lake Zirahuen, Patzcuaro and Chapala, and find but one species. G. xaliscone, described by Jordan and Snyder from Lago de Chapala. is evidently this same species.

The specimens from Lago de Zirahuen are much darker than those from other localities, and those from Patzcuaro are much the lightest.

Alimentary canal three times the total length of the fish; peritoneum black; gill-rakers to on the first arch.

This species is viviparous; one female from Patzcuaro 5.15 inches in length contained $3 \mathrm{I}$ young of about equal length, longest I.It inches. There was no modification of the anal fin in any of these young, as found in the adult male. This modification of the anal fin is a sexual character, which probably appears when the sexual organs develop.

Specimens from Patzcuaro were collected May 19 to 22, Zirahuen May 24 . and those from Chapala, June 2. The latter had spawned before our arrival. 
This specius deposits its young the latter part of May. Ocotlan; La Palma; La Barca: Patzcuaro.

\section{KEY TO TIL SPECIES OF GOOI)EA.}

a. Dorsal fin slightly behind ventral: distance from base of caudal to origin of dorsal 2 in distance from origin of dorsal to anterior margin of orbit.

b. Body slender, its depth $3 \frac{2}{3}$ in length of body; scales 37 to 40-1 3. D. 1 2: 1. 13 .

A'TRIPINXIS.

bl. Body deep, its depth 3 in length of body; scales 37-14; D. I 3: A. I 4 .

CA1.11:N1\%.

at. Dorsal fin slightly in advance of anal. distance from base of caudal to origin of dorsal i $\frac{4}{5}$ (small specimens), I $\frac{3}{5}$ (in larger specimens) in distance from origin of dorsal to the tip of the snout; scales +1-16; D. I3; I. It.

I.L'1T101,1)1.

SKIFFIL, gen. nov.

Type lime.

Body compressed, deep: dorsal in advance of anal. its middle over origin of anal: origin of dorsal fin midway between base of candal and eye: teeth loose, outer series large, bicuspid. behind which are small villiform teeth. Mlimentary canal elongate, its length 2 to 3: times the total length of the body: peritonemm liack: gill-rakers long, rather stiff, about 20 on the first arch: vertebra $16+18=3+$. 1 group of small fishes with compressed bodies and a short clistended abdominal region. I have placed Carachodon bilineatus bean in this genus. It has an alimentary canal a little more than twice the total length of the body. The teeth are bicuspid and loose. though scarcely as much so as in the other three species. The alimentary canal is elongate though less so than in the other species. It is possibly deserving of sub-generic rank, but our material is too scant to warrant any such disposition of it being macte at present. This genus is named for Mr. Ii. J. I'. Skilf, Director of the Field Columbian Nuseum.

Skiffia lermæ, sp. nov.

Type, No. 36r6. Fi. C. M. Length. 2.05 inches.

Locality, Lago de Patzcuaro, I'atzcuaro, Michoacan, Mexico. Head $t$ : depth $2: 3$ to $3 \frac{1}{4}$ : D. I $3:$. 1. It: scales $37-1+$. Body deep, much compressed: head small; snout pointed: mouth small; 
lower jaw the longer; snout + in head: eye large, 3 in head: interorbital slightly convex, its width $2 \frac{1}{4}$ in head; dorsal fin slightly in advance of anal, midway between base of caudal and posterior margin of orbit.

Gill-rakers rather stout, 20 on the first arch. Vertebræ $16+$ $18=3+$. Base of dorsal 2 in head, its height $\mathrm{I} \frac{1}{2}$ in females, slightly higher in the males: length of pectoral $1 \frac{1}{3}$ in head; ventral 2. Alimentary canal coiled on right side, its length $3 \frac{1}{3}$ times the total length of the body; peritoneum black; teeth bicuspid. loose.

Females light olivaceous above, much mottled with darker, nearly plain on lower half of body: young with a few faint brownish bars on lower half of caudal peduncle, a narrow dark lateral band and a prominent black bar at base of caudal. The color of the males is a nearly uniform dark olivaceous, the anterior half of some specimens being nearly black; the black caudal bar much less conspicuous than on the females; a dark line on underside of caudal peduncle in both sexes: anterior rays of dorsal much shorter than posterior rays. The fourth ray is less than half the ninth: longest dorsal ray $\mathrm{I}_{3}$ in head. The body of the males is rery much compressed, as that of the females. This fish bears such resemblance to $S$. mullipunctata from Ocotlan. from which it differs in having fewer dorsal rays, the anterior portion of the fin shortened, the less prominent caudal bar and the different coloration.

Largest specimen, a female, is 2.50 in length. The males are scarcely smaller than the females.

Viviparous; one female 2.50 inches in length contained 30 young with egg not quite all absorbed. . Length of young $\cdot 3+$ inch. These fishes were taken May ig to 2I. Their time for spawning evidently about one week later. Celaya: Patzcuaro.

Skiffia multipunctata (Pelligrin).

Head 4; depth 24: D. 16: A. 15: scales 33-12. Body deep. much compressed, snout short, rather pointed, its length + in head: month small: lower jaw slightly the longer: eve large. 3 in head

Dorsal slightly in advance of anal. its origin midway between base of caudal and eye: interorbital slightly convex, its width 2 in head.

Base of dorsal $1 \frac{1}{4}$ in head; height $I_{3}^{1}$ in female. slightly higher in the male. The anterior portion of the dorsal fin is not shortened as in the male of the preceding species. Pectoral $I_{3}^{1}$ in 
the head: ventral 2; alimentary canal elongate, $3 \frac{1}{3}$ times the total length of the body, coiled on the right side; peritoneum black.

Outer series of teeth loose, bicuspid, behind which are villiform teeth; gill-rakers long, rather stout, 20 on first gill-arch; vertebra $16+18=34$.

Female light olivaceous, a lark spot on hinder margin of each scale on upper half of body; these spots forming lines along the rows of scales as in Mollienisia. A prominent black caudal bar at base of caudal fin.

Male nearly uniform; anal and dorsal fins black, margined with yellow: black caudal bar indistinct.

Longest specimen a female, length 2.50 inches. Males not quite so large as the females.

Viviparous. The females all spawned out. They were collected June 2. Spawning time evidently the latter half of May.

\section{Skiffia variegata, sp. nov.}

Type, No. 3612, F. C. M. Length, I.95 inches.

Locality, Lago de Zirahuen, Zirahuen, Michoacan, Mexico.

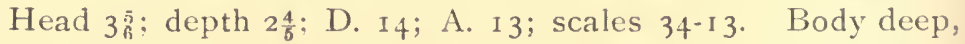
compressed; top of head convex; interorbital $2 \frac{1}{4}$ in head: mouth -small, lower jaw the longer, chin rather prominent; snout 4 in head; eye large, its diameter 3 in head; dorsal slightly in advance of anal, its origin midway between base of caudal and posterior margin of orbit; base of dorsal fin $I \frac{1}{2}$ in the head; height $1 \frac{2}{5}$ (in male $1 \frac{1}{4}$ ) in head; anterior dorsal rays short, the rays gradually increasing in length to eighth or ninth, which is longest; caudal truncate; pectoral $1_{3}^{1}$ in head; ventral 2 ; alimentary canal three times the total length of the body, coiled on right side; peritoneum black. Olivaceous, much mottled, an indistinct dark lateral band more or less broken in some specimens; four or five light brownish spots on lower portion of caudal peduncle, the under surface of which is dark. The color of the male is more uniform and darker than that of the female; no black caudal bar at base of caudal; chin black.

This species resembles $S$. lerma from Patzcuaro from which it differs in absence of black caudal bar, in being more slender and in coloration. Longest male, 1.70 inches in length. The longest specimen (a female) 2.25 inches in length, contained 18 young. well formed and with spots on their sides; length of young .53 incl. 
A second female, 1.54 inches in length, contained Io young, each .45 inch in length.

A third specimen, 2. 5 inches in length, contained 25 young, each .55 inch in length. These specimens were collected at Zirahuen, May 24. Spawning time for this species about the middle of May. This is the smallest species of the genus. Zirahuen; Chalco.

\section{Skiffia bilineatus Bean.}

A few specimens from Huingo. Longest female, 1.6o inches in length. One female, 1.50 inches in length, contained 27 young, which were very slender, white, and .32 inch in length. Collected May 26.

Dorsal fin of males much' higher than that of females. Posterior half of lateral band broken into 12 to 15 short irregular bars, a few of which extend almost to the dorsal fin. The upper half of the body has a few fine punctulations. The male is more slender than the female. Longest male, I. Io inches.

Spawning time about third and fourth weeks in May.

Alimentary canal slightly less than $2 \frac{1}{2}$ times the total length of body. Peritoneum black. The teeth are bicuspid and less firm than in other species of Skiffia.

Dorsal in advance of anal fin, its origin midway between base of caudal and middle of opercle. Huingo.

\section{KEY TO THE SPECIES OF SKIFFIA.}

a. A black bar at base of caudal (inconspicuous in some males of lerma, which have a uniform coloration and a very dark head).

b. Body light olivaceous in females, mottled with dark, nearly plain on lower half of body; males nearly plain; head usually quite dark; D. I 3 ; A. I4; scales 37-1.4.

LERUE.

bb. Light olivaceous in females, a dark spot on hinder margin of each scale on upper half of the body; these spots forming lines along the rows of scales; males nearly uniform; dorsal fin black margined with yellow; D. 16; A. I5; scales 33-12.

MUITHENCTATA.

a $\iota$. No black bar at base of caudal.

c. Body much variegated, D. It or I 5 ; A. I 3 to I 4 ; scales $3 t^{-1} 3$; alimentary canal three times total length of the body. VARIEGATA.

cc. Color uniform with a dark lateral band, which is divided on anterior third of body. D. 16; A. I6; scales 32-II. Alimentary canal 2 to $2 \frac{1}{2}$ times total length of body, origin of dorsal midway between base of caudal and nape. 
Heterandria lutzi, sp. nov.

Type, No. 3718. ['. C. M. Length, 2.33 inches.

Locality, Rio Quiotepec, Cuicatlan, Oaxaca, Mexico.

Head $4 \frac{1}{6}$; depth $3 \frac{1}{2}$; D. 7 ; A. 8; scales 29-8. Hody elongate. rather slender; mouth terminal. jaws equal, giving the head a wedse-shaped appearance; snont $3 \frac{1}{2}$ in the head; eye larere. $3 \frac{1}{1}$ in the head; teeth in one series, conical. curved backward at the tips. movable. Peritoneum black; intestine much conroluted hut not in definite coils, its length about $I \frac{1}{2}$ times the total length of the hody. Modified anal fin of male long, slender. pointed with curved tip, its length $2:_{: 3}^{1}$ in length of the body: origin of anal in male midway between base of caudal and tip of snout; orisin of dorsal slightly behind origin of anal in females. being midway between base of caudal fin and posterior margin of opercle. Base of dorsal 3 in head, height $1 \frac{1}{2}$; pectoral I $\frac{1}{4}$; ventral 2.

Olivaceous, a narrow dark lateral band broken into smali round or oblong spots. generally from 12 to 18 on one side; the small round spots scarcely as large as pupil; iris biack. a narrow dark streak on under side of caudal peduncle; a faint vertebral streak. more conspicuous in the young.

This species differs from $/ I$. pleurospilus in having a lateral band broken into small spots on sides, and the more advanced position of the dorsal fin. This is the only species of Heterandia known at present from Mexico.

Longest female. 3.I 5 inches: longest male, I-49 inches. Viviparous; egges partly hatched; ont female, 2.59 inches in length, contained to young, each coiled about the yolk, and 26 exress; a second female 2.15 inches in length contained II young and $S$ exgs. Each of the partially hatched young are .35 of an inch in length. Specimens collected as follows: Oaxaca, Mlay 4: Cuicatlan, May 5; Venta Salada, May 6. The young are evidently deposited abont the midule of Miay. Named for Mr. Frank Eugene Lutz. who accompanied me in Mexico as volunteer assistant. Oaxaca: Cuicatlán: Vienta Saladá.

\section{Poecila limantouri Jordan \& Snycler.}

Intestinal canal elongate, coiled on ventral and right side in about 7 coils: length of intestine about $+\frac{1}{3}$ times total length of the body; peritoneum black. Viviparous; females with eggs, the young not dereloped: one female 3.06 inches in length with I 5 eggs: another 2.9 inches in length with 95 eggs. Largest 
female, 3.75 inches in length. The males average smaller than the females. Puente de Ixtla; Balsas; La Antigua.

Xiphophorus jalapæ, sp. nov.

Type, No. 3724, F. C. M. Length, 2.76 inches.

Locality, Jalapa, Vera Cruz, Mexico.

Head 4 ; depth $3 \frac{1}{3}$; D. I3; A. 9; scales $28-8$. Body elongate; not very robust, but with a deep caudal peduncle; head flattish, wedge-shaped; mouth rather small, lower jaw the longer; outer series of teeth pointed and loose, behind which is a band of smaller conical pointed teeth; peritonenm black; intestinal canal elongate, on ventral surface and right side, with 4 coils on the right side, its length $I_{1}{ }_{1}^{i}$ the length of the body.

Eye large, 3 in head; snout $3 \frac{1}{2}$; interorbital broad, little convex, its width 2 in head; base of dorsal $I \frac{1}{5}$ in the head, longest dorsal ray $1 \frac{4}{5}$ in head (in $\delta I_{5}^{2}$ in head); pectoral $I_{5}^{\frac{1}{5}}$ in head; ventrals $1 \frac{3}{4}$; caudal sub-truncate; origin of dorsal fin midway between base of caudal and middle of snout, being well in advance of the anal. The male is more slender than the female. Head of male $+\frac{1}{5}$, depth 4. Caudal appendage pointed, its length $I_{5}^{2}$ in the length of the body. Modified anal of the male rather short and thick, length $I \frac{1}{4}$ in head; a notch on under side near its tip; ventrals of male long, slender, and pointed, their tips nearly reaching tip of anal fin; length of ventral fin of male equal to length of the head; origin of ventrals in both sexes well in adrance of dorsal fin.

Female, olive brown above, nearly plain white below; these colors are separated by a narrow lateral band. which extends around snout on upper half of the body; the middle of each scale is darker, giving faint brownish lines on side; a dark line on under side of caudal peduncle: dorsal fin with two rows of black spots near the base, other fins plain.

The color of the male is similar to that of the female, except the dark lateral band extends on caudal and forms the upper black margin of caudal appendage. There is a second lateral band from lower angle of pectoral to origin of anal fin, and a dark streak on rentral surface of caudal peduncle which forms the lower black margin of caudal appendage. In life the middte of caudal appendage and lighter portion of lower half of the body is a bright yellow: Dorsal fin on hoth sexes spotted. Longest female, 2.95 inches. Longest male (without appendage), 3 inches in length. 


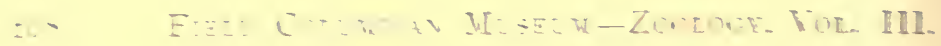

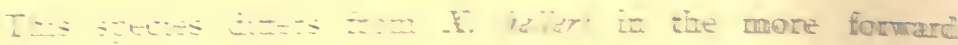

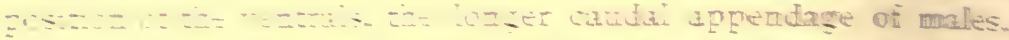
柁

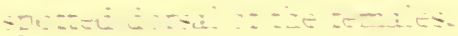

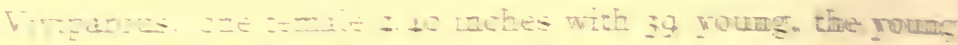

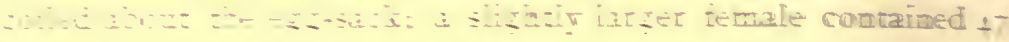

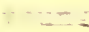

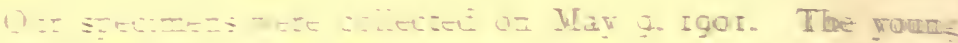

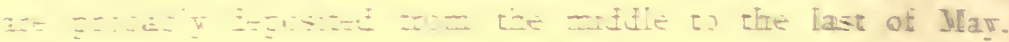

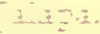

\section{$\therefore$ IHERINID.E.}

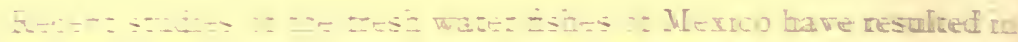

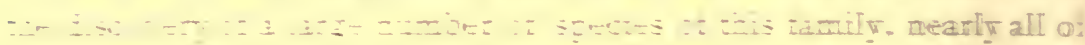

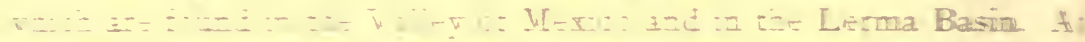

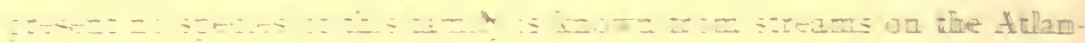

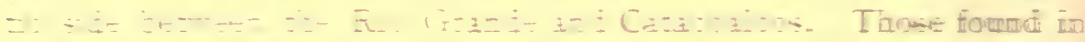

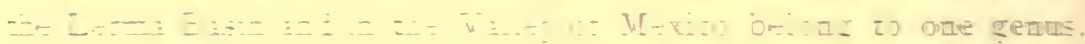

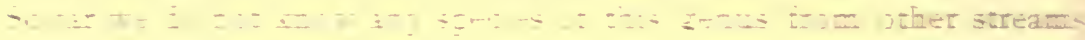

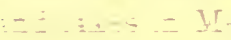

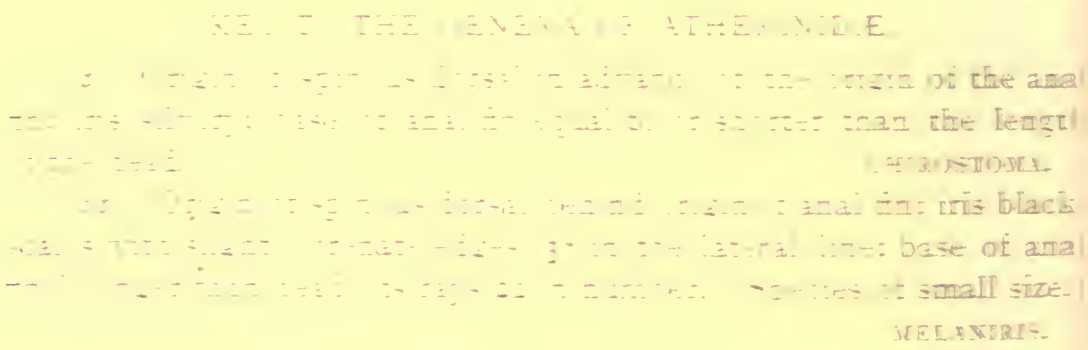

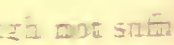
$2=7= \pm$. It seem

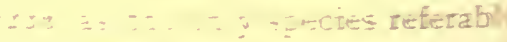

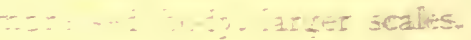
$\because:-1 \pi=3^{\overline{3}}$. 1 ail o-luer spectic

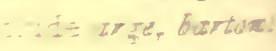

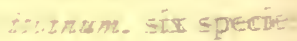
¡2: mertebra 3 
species, all with scales having the edges more or less crenate. This group would comprise two species of small size (grandocule and chapala), one of medium size (promelus) and three species of large size. Scales 49 to 70 ; gill-rakers 24 to 27 . Vertebræ 43 or 44 . The firmness of the flesh and the opaque color cannot be correlated with any other character. If divided on this basis, arge, humboldianum (except from Patzcuaro) and estor from Xochomilcho and Zirahuen, would be included. In the key I have placed all small species with large scales, fewer than 45 in the lateral series, in one division (Eslopsarum). All other species with scales having entire edges (Chirostoma), in a second, and all species with scales having crenate edges (Lethostole), in a third.

The species of this genus are very variable, and are perhaps not yet well differentiated. The environment of the species of this genus is very diverse; some species are found in clear running water, others in lakes like Chapala, which has several inlets and a large outlet, while many of the species are in lakes which have no outlet, of which Patzcuaro, Zirahuen and the lakes in the Valley of Mexico are good examples. Some of these lakes are quite fresh; others, as Quitzeo and Patzcuaro, are quite brackish. So far as I could learn Quitzeo is the most brackish of all, and Patzcuaro probably next; and in these two lakes the fishes were much lighter in color than those from other places. The darkest colored fishes were taken from Lago de Chalco and Lago de Zirahuen.

The alimentary canal of Chirostoma is shorter than the total length of the body. The peritoneum is black. A few stomachs examined indicate the food to be insect larvæ and insects. In one specimen of $C$. estor the stomach contained a partly digested Chirostoma. I was told that these fishes will not take a hook. The larger species are excellent eating, the flesh being firm and white when cooked and not full of small bones. The smaller species and the young of the larger ones, together with all of the species of Paciliida are dried in large quantities by the Indians and are thus shipped to neighboring towns, or are kept for future use. All of the fishes caught in the larger fresh waters of Mexico are eaten-none being thrown aside as of no value.

At Patzcuaro, Zirahuen, Chapala and Quitzeo the fishes are caught in long seines. These seines have coarse mesh near the end, which becomes gradually smaller until the large bag in the middle has about $\frac{1}{4}$ inch mesh. The shore of the lake is often not suitable for drawing the net. It is thrown out in the usual way, drawn by ropes from the shore until the ends of the net are near each other. 
A boat is then anchored some distance from the shore at the edge of the vegetation or of the deep water and into it the net is pulled. The species of this genus evidently spawn in the late summer or fall. Those taken the latter part of May had the ovaries very little developed. The individuals of the species of large size belonging to this genus seldom exceed a foot in length.

\section{KEY TO THE SPECIES OF CHIROSTOMA.}

a. Scales large, fewer than 45 in the lateral line, edges of scales entire, vertebræ usually fewer than 40. Species of small size. (Eslopsarum.)

b. Mouth small very oblique; snout short, 4 in the length of head; base of anal equal to or slightly longer than head; anal rays i 6 to 18 . Teeth very minute; scales with entire edges, 37 or 38 in the lateral line.

JORDANI.

b6. Mouth larger, less oblique; snout longer, $2 \frac{1}{2}$ to $3 \frac{2}{3}$ in the length of the head; base of anal equal to or shorter than the head.

c. Origin of spinous dorsal over tips of ventrals, midway between base of caudal and nostril.

d. Body robust, its depth $4 \frac{1}{3}$ in the length of the body; base of anal $I \frac{1}{5}$ in the head, its rays 16 or 17 ; scales 38 to fo-II. Teeth large, sharp, in two definite rows in each jaw. Gill-rakers long and slender, $3+\mathrm{II}=\mathrm{I} 4$ on first arch.

ARGE.

dd. Body slender, its depth 6 in the length of the body, scales 42-10; anal rays I5: gill-rakers long and slender, + + I 7 on the first arch.

BARTONI.

cc. Origin of spinous dorsal over middle of ventrals, being nearer tip of snout than base of caudal by a distance equal to the diameter of the eye; base of anal $1_{5}^{2}$ in the head, its rays 13 or 14 ; gillrakers $4+18=22$. Teeth very small.

ATTExUATUM.

ccc. Origin of spinous dorsal over space between tips of ventrals and origin of anal fin, midway between base of caudal and posterior margin of orbit. Base of anal fin equals length of the head, its rays 20. Teeth large, in a single row, except near tip of upper jaw where there are a few large canine-like teeth; scales 42 -I 2 ; gill-rakers $4+13$.

LABARCE.

aa. Scales smaller, more than +5 in the lateral line; edges of the scales usually crenate; vertebræ more than 40.

$e$. Scales entire; base of anal abotit $\mathrm{I}_{5}^{2}$ in the length of the head, its rays 13 to I9; snout 3 to $3 \frac{1}{4}$ in the length of the head. (Chirostoma.)

$f$. Origin of spinous dorsal nearer tip of snout than base of caudal. 
s. Anal rays 17 ; gill-raters $t+21=25$; scales $48-12$; body light, translucent, slightly compressed; depth $5 \frac{1}{4}$. Origin of spinous dorsal slightly nearer tip of snout than base of caudal.

PATZCUARO.

$\therefore$ Anal rays 13 or $1+$; gill-rakers $t+17=21$; scales $5 t^{-12}$. Body dark, opaque, scarcely compressed; depth 6 $\frac{1}{3}$; origin of spinous dorsal nearer tip of snout than base of caudal by a distance greater than diameter of eye.

ZIRAHUEX.

$f f$. Origin of spinous dorsal midway between base of caudal fin and anterior margin of the orbit, or the nostril; anal rays 17 to 19 ; scales $5+$ - I5; gill-rakers $t+15=19$. Species of large size.

HUMBOLDTAXUM.

ei. Scales with crenate edges: origin of spinous dorsal nearer base of caudal than tip of the snout; anal rays is to 24. (Lcthostole.)

ih. Snout short, $3 \frac{1}{4}$ in length of the head, being equal to or shorter than the diameter of the eye. Species of small size:

i. Scales in lateral series 49. transverse I3: anal base equals the length of the head. its rays $2 \mathrm{I}$.

CHAPALE.

ii. Scales in the lateral series 62, transverse' ${ }_{+}$: base of anal fin $I \frac{1}{3}$ in the length of the head, its rays $I 9$.

GRANDOCLLE.

hh. Snout long, $2 \frac{1}{2}$ to $2 \frac{3}{3}$ in the length of the head: diameter of eye $+\frac{1}{2}$ to $5 \frac{3}{4}$ in head. Species of large size.

k. Upper jaw decidedly longer than the lower, mandible $2 \frac{1}{2}$ in the head: tip of snout black: base of anal fin $I \frac{1}{2}$ in the head, its rays 19 or 20 ; scales 53 to $56-15$ : teeth large, not in definite rows: snout $2 \frac{1}{2}$ in head: diameter of eye $5 \frac{3}{3}$ : gill-rakers $5+19$.

PROMELAS.

$k k$. Lower jaw decidedly longer than the upper: mandible $I_{5}^{4}$ to $2 \frac{1}{5}$ in the head: tip of jaws not black (dusky in some specimens).

l. Scales between dorsal fins very small, more than 20 in a series between the fins; scales 60 to $70-22$ : gill-rakers ?+23; teeth large anteriorly, canine-like, not arranged in definite rows: mandible 2 in head.

SPHR.ENA.

11. Scales in the region of dorsal fins larger, fewer than 15 in a series between the two fins.

$m$. Scales in the lateral series $5+$ to 60 .

n. Lower jaw projecting but little beyond the upper mandible, about $2 \frac{1}{5}$ in head.

o. Teeth weak, in patches, not arranged in definite rows: gillrakers $4+23$ : scales 56 to 60 - I 8 ; mandible $2 \frac{1}{6}$ in head.

i.cicilis.

oo. Teeth large and strong, in two definite rows, the larger teeth on inner row of upper jaw and outer row on lower: mandible $2 \frac{1}{5}$ in head; gill-rakers $5+20$; scales $58-20$.

l.ERMA.

$n n$. Lower jaw projecting much beyond the upper, mandible $\mathrm{I}$ 
in the head: teeth on jaws small, in bands; scales 5t to 57-19: gillrakers $5+20$ : base of anal fin $\frac{1}{2}$ in hand, its rays 20 . ocritaxi.

$m m$. Scales in the lateral series 70 , transverse 18 ; teeth on jaws large and wumerous, not arranged in definite rows, usually 1 to 3 large teeth on vomer; base of anal $1 \frac{1}{2}$ in head, its rays 18 to 19.

ESTUR.

Chirostoma jordani Voolman.

This is one of the smallest species of the genus. Its short snout and very oblique mouth at once distinguishes it from all other species. It is perhaps more proper to restrict the nst of Eslopsarum to this species only. Gill-rakers $++1+=18$ : vertebra $21+17=38$; length of longest specimen, 2.75 inches. Chalco: Texcoco.

Chirostoma arge Jordan \& Snyler.

A small species so far found only in streams. Gill-raliers $3+11=14$; vertebra $18+18=36$. Length of longest specimens, 2.75 inches. Iguas Calientes; Lagos.

Chirostoma bartoni (Jordan \& Evermann).

Two specimens of this species from Lago de Lerma, near the City of Lerma in the State of Mexico, were presented to this Museum by the United States National Museum. The scales of one of these specimens has crenate edges and is very roligh: on the other specimen the scales are very smooth, as they are on the type; which I have been permitted to examine. Scales slightly more crowded on the nape than is usual in the more nearly related species. Origin of dorsail fin slightly nearer tip of sinout than base of caudal fin.

Chirostoma attenuatum, sp. nov.

Type. No. 363 I, I: C. M. Length, 3.25 inclues.

Locality, Laso de Patzcuaro, Patzcuaro. Michoacan, Mexico. Head $4 \frac{1}{2}$ : depth $5 \frac{1}{2}$ : D. V-9; .1. 13; scales $4^{2-1}$ I. Hody rather slender. not much compressed; caudal peduncle long and slender; lower jaw slightly the longer: snout pointed, $3 \frac{1}{2}$ in the head; mandible 3 ; interorbital space 3 ; maxillary reaching vertical from front of orbit; mouth suall, oblicue, but much less so than in $C$. jordani. Teeth very small, mumerous in both jaws, those in the upper jaw mostly in two series; in a band in lower jaw; scales large with entire edges. those on the nape 
slightly reduced in size. Origin of spinous dorsal over middle of ventrals and being nearer tip of snout than base of caudal by a distance greater than diameter of eye; eye $3 \frac{2}{5}$; length of pectoral fin $\mathrm{I} \frac{1}{2}$ in head; ventral $2 \frac{1}{5}$; base of anal $\mathrm{I} \frac{2}{5}$; gill-rakers $4+18=22$ : vertebræ $23+20=43$.

Light olivaceous, translucent; smallest specimens $\left(2 \frac{3}{4}\right.$ inches in length) darker, more opaque: silvery band on sides narrow. inconspicuous under the pectoral tin, being widest on anterior part of the caudal peduncle.

Species of small size, common in Patzcuaró Lake.. This species is characterized by large scales, the anterior position of the dorsal fins, the short anal fin, and the long slender caudal peduncle. Patzcuaro.

Chirostoma labarcæ, sp. nor.

Type, No. 3640, F. C. II. Length, 3.68 inches.

Locality, Rio Lerma, at La Barca, Jalisco, Mexico.

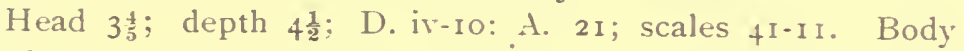
slender, compressed; snout rather long, pointed, its length 256 in length of the head; lower jaw slightly the longer; eye $3 \frac{3}{4}$ in head; interorbital 3; mouth moderate, not very oblique, maxillary reaching slightly beyond anterior margin of the eye; length of the mandible $2 \frac{1}{3}$ in head; a single series of large teeth - in each jaw, a few smaller teeth behind these, a few near tip of jaws large and canine-like. Scales large with edges entire, those on the nape very slightly reduced in size; origin of spinous dorsal over vent, midway between base of caudal and pupil; base of anal fin equals length of head, its rays 20 to 21 ; length of pectoral fin $1 \frac{1}{4}$ in the length of the head; ventral fins 2 in head: gill-rakers $++13=17$.

Light olivaceous, translucent; a few dark dots on margins of scales on upper half of body; lateral band narrow, the portion under the edge of the pectoral indistinct. and made up of a few dark dots.

Species of small size, the longest $3 \frac{3}{4}$ inches in length. This species differs from others with large scales in having a longer snout. the posterior position of dorsal fins. the long anal fin and the strong dentition. Apparently scarce. La Barca; La l'alma.

Chirostoma patzcuaro, sp. nor.

Type, No. 3628 , F. C. .1. Length. 3.68 inches.

Locality. Lago de Patzcuaro, Patzcuaro, Michoacan, Mexico. 
Head $4 \frac{1}{4}$; depth 51; D. V-10; A. I7; scale's 48-12. Body slender, moderately compressed; snout short, pointed. its length 31 in length of head; lower jaw slightly projecting beyond upper; mouth oblique, but less so than in $C$. chapala; mandible $2: 3$ in head: diameter of eye $3 \frac{3}{4}$ in the head; teeth small. numerous, in a narrow band on anterior part of each jaw, becoming, laterally. in two series; scales moderately large, edges entire, those at the nape slightly reduced in size; origin of spinous slightly nearer tip of snout than base of caudal; base of anal fin $1 \frac{1}{4}$ in length of the head; pectoral $1 \frac{1}{2}$; ventral 21; gill-rakers $4+21=25$.

Licht olivaceous, translucent, lateral band narrow.

Species of small size, less than 4 inches in length. Seven specimens from Lago de Patzcuaro. Apparently scarce.

This species resembles $C$. chapala, from which it differs in having a less oblique mouth, a shorter anal fin and a less compressed loody. Patzcuaro.

Chirostoma zirahuen, sp. nov.

Type, No. 3609 , F. C. M. Length. 3.55 inches.

Locality, Lago de Zirahuen. Zirahuen, Michoacan, Mexico.

Head $4 \frac{1}{4}$; depth $5: 3$; D. v-10; A. I 3 ; scales 5t-12. Body elongate, nearly terete. less compressed than in any other Chirostoma: mouth moderately oblique, lower jaw slightly the longer; length of snout equal to diameter of eye, $3 \frac{1}{3}$ in length of the head; interorbital broad. 3 in head; teeth very small, in a narrow band in each jaw. Base of anal fin $1 !$ in heall pectoral I! ; ventral 2; scales with entire margins; origin of the dorsal fin nearer tip of snout than base of caudal by a tistance greater than diameter of eye; caudal peduncle long and slencler; gillrakers $4+\mathrm{I} 7=2 \mathrm{I}$ : vertelora $23+\mathrm{I} 8=4 \mathrm{I}$.

- Dark olivaceous above, lighter below; opaque. This species is one of the clarkest found in the Lerma basin. It is the most abundant species in Lago de Zirahuen.

Species of small size. It is characterized by its lark opaque color. its terete body, the backward position of the dorsal fin, and the short anal fin whose rays are 13 or $1+$.

The longest specimen in our collection is 4.13 inches in length. Abundant in Lago de Zirahuen. Zirahuen.

Chirostoma humboldtianum (C. \& I:)

Pescada Blanca.

This species is very abundant in the lakes about the City of 
Mexico. It is one of the largest species of the genus, though it seldom reaches a length of 12 inches. Specimens from Lago de Chalco are very dark, while those from Lago de Patzcuaro are very light and translucent. Specimens from Lago de Xochomilcho are intermediate. Scales entire; gill-rakers $5+$ I $3=18$; vertebra $23+19=42$; teeth small, in a narrow band in upper jaw, in two series in the lower. There are often with a few large teeth on the vomer, as in $C$. estor.

The ovaries not well developed; eggs small, spawning season evidently late in the summer. Chalco; Xochomilcho; Patzcuaro.

Chirostoma chapalæ Jordan \& Snyder.

This species is very white and translucent. It is a small species, seldom reaching a length of + inches. Edges of scales crenate; gill-rakers $6+24=30$; vertebre $24+20=44$. Very abundant in Lago de Chapala. Ocotlan; La Palma.

Chirostoma grandocule Steindachner.

Edges of scales crenate; base of anal fin $I_{3}^{1}$ in length of the head, its rays 19 ; snout $3 \frac{2}{5}$ in head; mandible $2 \frac{1}{3}$; eye $3: 3$; teeth minute, in narrow bands on each jaw, approaching two series laterally; gill-rakers $5+22=27$; vertebra $23+20=43$ : species of small size. the largest specimens about $+\frac{1}{2}$ inches. This appears to be the most abundant Chirostoma in Patzcuaro Lake. Ocotlan; La Palma; Patzcuaro.

Chirostoma promelas Jordan \& Snyder.

This is the only species of Chirostoma so far known which has the upper jaw decidedly longer than the lower. The tip of the snout is black, otherwise the color is light and translucent. Edgres of scales crenate; gill-rakers $5+19=24$. This species is not abundant; size medium. Our largest specimen is $+\frac{1}{4}$ inches in length. The longest specimen collected by Jordan d Snyder is 7 inches in length. Ocotlan; La Palma.

Chirostoma lucius Boulenger.

This is evidently the species described by fordan d suyder ats C. crystalinum in a foot-note * Dr. Jordan expressed the opinion that $C$. lucius is identical with $C$. lerme. "The teeth of $C$. lucius are described as small, while $C$. lerme has very laree strong teeth.

(* BuI. L.S. F. C. 1900. 2:3 . । 
Gill-rakers $++23=27$. Length 9.35 inches. Species of large size. La Barca; Ocotlan; La Palma.

\section{Chirostoma sphyræna Boulenger.}

This is $C$. diazi Jordan $\mathcal{E}$ Snyder. This species was not taken by us, neither did we get $C$. estor from Lago de Chapala, its type locality.

Chirostoma lermæ Jordan \& Snyder.

Of the species of large size of this genus, this one has the strongest dentition. It is known at present only from Lago de Chapala. Gill-rakers $5+20=25$; base of anal $1 \frac{1}{2}$ in head, its rays 20; length of mandible $2 \frac{1}{y}$ in head; diameter of eye $5 \frac{1}{2}$. Species of large size. The largest in our collection is 9.35 inches in length. Not very abundant. La Palma; Ocotlan.

Chirostoma ocotlanæ Jordan \& Snyder.

This species is easily recognized by its projecting lower jaw, which extends beyond the upper a distance greater than diameter of pupil. Teeth minute, in bands; gill-rakers $5+20=25$; vertebre +4. Species of large size, longest ro.7t inches. Ocotlan; La Palma.

Chirostoma estor Jordan.

This species was originally described from Lago de Chapala. It was later described by Dr. Steindachner from Lago de Patzcuaro as $C$. alluss. The identity of $C$. allus and $C$. estor was questioned by Jordan and Evermann from the fact that there were no teeth on the vomer of the specimens in Dr. Steindachner's possession. A large number of specimens from Patzcuaro examined by me show that the presence of vomerine teeth is the rule rather than the exception.

In our collection are specimens from Lago de Patzcuaro, Lago de Zirahuen, and Lago de Xochomilcho. Those from the first mentioned lake are more slender and much lighter and more translucent than those from the other lakes. The general appearance of those from the last two lakes is that of $C$. humboldidinum, and at first sight they are easily mistaken for that species.

Our specimens are from three lakes without outlets; two of the lake's are but ro miles apart, while the other is considerably remote. Since isolation, this species in each lalie has been undergoing some change, but not sufficient to give them rank as species or 
sub-species. In the specimens from Zirahuen the teeth are smaller and usually in bands, rather than in two series; vomerine teeth usually present.

The anterior part of the head in a few specimens from Patzcuaro is nearly black, that of others is dark, while that of most is very light. Base of anal $\mathrm{I} \frac{1}{2}$ in head, its rays 18 to 20 ; scales 7O-1 7 ; gill-rakers $5+2 \mathrm{I}=26$; vertebræ $23+20=43$. This species reaches a length of about 11 inches. It is an excellent food fish. Abundant. Xochomilcho: Patzcuaro; Zirahuen. Lago de Chapala is the only other locality from which this species is known.

\section{MELANIRIS, gen. nov.}

Type, balsanus.

This genus differs from Chirostoma in having a rounded lower jaw, a longer anal fin, a short caudal peduncle, and in having the origin of the spinous dorsal fin behind that of origin of anal fin. In all of the specimens the iris is black. In Chirostoma it is silvery.

Peritoneum black, alimentary canal shorter than total length of the fish. Vertebra $17+19=36$.

Melaniris balsanus, sp. nov.

Type, No. 3706, F. C. M. Length, 2.68 inches.

Locality, Rio Balsas, Balsas, Guerrero, Mexico.

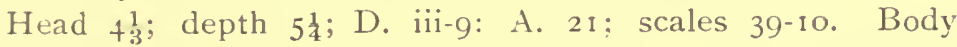
elongate, slender, not much compressed; snout rounded laterally; mouth small, lower jaw slightly the longer; caudal peduncle very short. Dorsal fins posterior, origin of spinous dorsal considerably behind origin of anal fin, and midway between base of 'caudal fin and posterior margin of opercle; outer row of teeth large, caninelike, wide apart; behind these a band of small villiform teeth; base of anal ${ }_{3}^{1}$ longer than head, its rays varying from 20 to 23 ; dorsal spines 2 to 4 , usually 3 ; pectoral fin high on sides of body, its length I $\frac{1}{4}$ in head; ventrals $2 \frac{1}{4}$; gill-rakers $4+\mathrm{I} 3=17$; vertebra $17+19$ $=36$; scales large, with entire margins. Olivaceous, rather opaque, dorsal region finely punctulate with black. A well detined silvery band on sides.

Very abundant in Rio Cuculo and the Rio Balsas, at Balsas. A small species seldom reaching a length of $2 \frac{3}{1}$ inches. It appears firmer as to its flesh than any of the species Chirostoma. Ovaries large, evidently nearing the spawning time. The ovaries of this species taken April 22 and 23 are much larger than those 
in different species of Chirostoma taken the last week in May. Balsas.

\section{MUGILIDE.}

\section{Agonostomus nasutus Gunther.}

The lips of some of the specimens from the Balsas are much thinner than in the one large ( 6 inches in length) specimen from Cuicatlan. Specimens from Balsas 3.75 inches in length. head 3:. Balsas: Puente de Ixtla; Cuicatlan.

Mugil trichodon Poey.

A few small specimens from La Antigua.

CENTRARCHIDA.

Lepomis occidentalis, sp. not.

Type, No. 3660, F. C. M. Length, 4.75 inches.

Locality, Rio Conchos, Jimenez, Chihuahua, Mexico.

Head 2: depth 2; D. X-II: A. iii, 9; scales 7-37-I 4. Body oval, compressed, dorsal outline more arched than the ventral. In smaller examples the profile is nearly straight or slightly convex. In large examples (about 5 inches in length, the profile is concare, with a prominent angle at the nape: mouth moderate, the tip of the maxillary reaching rertical from pupil. its length 3 in head; lower jaw slightly the longer: eye small, $+\frac{1}{5}$ in head and $I_{5} \frac{1}{3}$ the interorbital space; fins rather low. th dorsal spine $3 \frac{1}{4}$ in head: pectoral short and rounded, its length $I_{4}^{3}$ in head; ventrals slightly longer than the pectoral, their tips almost reaching anal; operculum with a well developed membranous appendage or flap, this being largest in the larger specimens. This flap has a narrow pale border. The candal fin is rery short. its lobes rounded and of equal size, its lenerth $1 \frac{3}{4}$ in head. Teeth on vomer, none on palatines; no supplemental maxillary. Gillrakers short, biunt, s on lower part of gill-arch.

Dark olivaceous above, lighter below, each scale with a light margin forming longitudinal lines along the rows of scales. Thest lines are quite prominent on the lower half of the hody: No black markings on the funs; no blue lines on the cheeks. a few dusky brown lines being present. Lenerth about 6 inches.

This species resembles Lefomis mesalotis; it differs from that species in having a more rolust hody. smaller eye, a much shorter pectoral fin, a much duller coloration and the alsence of bright blue stripes on the cheeks. It differs from L. haplegnatius in 
having a much deeper body, no blue stripes on the cheeks and a smaller eye.

Ovaries well developed, spawning season probably the latter part of July or early in August. Abundant at Jimenez; one specimen also taken at Santa Rosalia. Jimenez; Santa Rosalia.

\section{PERCIDE.}

\section{Etheostoma pottsii (Girard).}

This species is quite abundant in the head waters of the tributaries of the Rio Conchos. With the following species it is the most westerly of the group to which it belongs. Very few other darters, if any, are found at as high an altitude as are these two species. E. horeale, found in Hudson Bay and St. Lawrence Basins, is its most nearly related species. San Andres; Santa Rosalia; Chihuahua; Jimenez.

Etheostoma australe Jordan.

Found with the preceding. Very abundant. No darters have yet been found in the head waters of the Rio Yaqui, though this river seems to have gotten its fauna from the head waters of the Rio Conchos or other tributaries of the Rio Grande. San Andres; Santa Rosalia; Chihuahua; Jimenez.

\section{CENTROPOMIDE.}

Centropomus undecimalis (Bloch).

Common at La Antigua.

Centropomus ensiferus Poey.

A few small specimens from La Antigua, largest 2.50 inches.

\section{GERRID E.}

Eucinostomus harengulus Goode \& Bean.

La Antigua, common.

$$
\text { CICHLIDA. }
$$

Cichlasoma eigenmanni, sp. nov.

Type, No. 3712, F. C. M. Length, 6.65 inches.

Locality, Rio Tehuacan, Venta Salada. Pueblo. Mexico.

Head $3 \frac{1}{3}$; depth $2 \frac{2}{3} ;$ D. xrii, I4 $\quad$ I. V.. Io; scales 6-33-11. Body rather elongate, profile convex but not very stuep; mouth 
small, scarcely oblique. jaws equal; lips thin, a distinct frenum; eye small, its diameter 41 in the head; inferior margin of the orbit above level of upper lip; snout long, $2 \frac{1}{3}$ in head; onter teeth large, brown at the tips; cheeks with six rows of scales. Origin of dorsal fin over gill opening; first dorsal spine short, the others gradually increasing to th $^{\text {th }}$ which is $2 \%$ in head; last dorsal spine $2 \frac{1}{2}$ in the length of the head; middle rays of soft dorsal and anal fins longest, the fins pointed, the tips of longest rays not reaching to base of caudal; longest dorsal ray $\mathrm{I}_{4}^{3}$ in head; longest anal ray $1 \frac{1}{2}$ in head; caudal fin slightly emarginate; least depth of caudal peduncle equals length of the snout; pectoral fins short, $I_{3}^{1}$ in head; ventrals $I \frac{2}{5}$ in head, the latter not gute reaching vent.

Brownish, six indistinct dark bands on sides, a darker lateral hand which ends in a black spot at the base of the caudal; fins all plain.

One smaller specimen, 3.85 inches in length, has head $3 \frac{1}{4}$; depth 256 ; scales 6-33-I I, longest dorsal ray $1 \frac{3}{5}$ in head; longest anal $\mathrm{I} \frac{3}{4}$. The dark bars and lateral hand are less distinct: a black candal spot; a few brownish streaks on lower half of dorsal and anal fins; the tips of pectorals reaching vent.

This species appears nearest $C$. intermedium. It differs from that species in having a higher spinous clorsal, and lower soft dorsal, and the absence of whitish ocelli on vertical fins. Venta Salada.

Cichlasoma parma (Gunther).

A few small specimens from La Antigua, largest 1.3 inches, lody with cross bars, a black bar at base of caudal.

Cichlasoma melanurum (Gunther).

I few specimens were taken in the Rio Quiotepec at Cuicatlan.

Heros istlanus Jordan of snyder.

This species is very abundant in Rio Ixtla at P'uente de Ixtla, and in the Rio Balsas at Balsas.

$$
\text { (GOBHID.E. }
$$

Philypnus dormitor (Lacépède).

Common at La Antigua. Largest specimen ro inches in length. 
Awaous taisiaca Lichinstein.

La Antigua; Balsas; Puente de Ixtla.

Gobius parvus, sp. nor.

Type, No. $373^{8}$, F. C. M. Length, I.95 inches.

Locality, Rio San Francisco, La Antigua, Vera Cruz, Mexico.

Head 4 ; depth $4^{\frac{1}{2}}$; D. vi-II; A. 12; scales 30 . Body short, robust: head large; snout blunt, rounded; mouth slightly inferior, little oblique, its gape extending to vertical from pupil; eye small, partly superior; interorbital area narrow, its width little less than half diameter of eye: diameter of the eye $3 \frac{1}{2}$ in the length of the head; snout $t^{\frac{1}{2}}$ in head; dorsal fins not connected, the spinous dorsal of females low, longest spine a little more than half the length of the head; in the male the dorsal spines are about $\frac{1}{4}$ to $\frac{1}{2}$ longer than the head, the tips extending to middle of dorsal fin: caudal long and pointed, its length in the female $3 \frac{1}{2}$ in the length of the body, in the male 3 ; pectoral slightly less than length of head: ventral $I_{5}^{1}$ in head; scales ctenoid.

Dark olivaceous, mottled with darker; a dark bar on dorsal region from base of posterior half of spinous dorsal; this bar is followed by three others from base of soft dorsal and one on caudal peduncle; 5 or 6 narrow dark. streaks on lower half of sides extending downward and forward to base of anal; 2 black spots at base of caudal fin; dorsal fins of both sexes barred; caudal fin of female with narrow dark bars, none on males; anal fin with a dark margin.

This species resembles $G$. stigmaticus. It is more robust and of different coloration. Longest specimen $2 \frac{1}{4}$ inches. La Intigua.

Gobius claytonii, sp. nov.

Type, No. 37 40, F. C. M. Length. 2.30 inches.

Locality: Rio San Francisco, La Antigua, Vera Cruz, Mexico.

Head $3 \frac{3}{3}$ : depth $5 \frac{1}{2} ;$ D. vi-12; A. I3; scales $42-15$. Hody elongate, subterete and tapering to caudal; head moderate: snout very blunt: mouth terminal, broad, its gape horizontal: eyes large, high upon the head and close together; interorbital width less than half diameter of pupil; diameter of eycerjuals the length of the snout, $3 \frac{2}{3}$ in length of the head: no scales on dorsal surface in front of spinous dorsal; scales ctenoid: breast and region under ventral without scales; spinous dorsal low. longest spine about 2 length of the luead; caludal fin long and pointed. its mid- 
dle rays the longest, about $\frac{1}{4}$ longer than the head; pectoral $1 \frac{1}{6}$ in the head; ventral I 1 . Color light olivaceous, somewhat reticulated above; side with 5 oblong dark blotches, the last and smallest one forming a black caudal spot; spinous and soft dorsal barred; candal fin barred; other fins plain; the middle portion of ventrals, except a small central light patch, blackish; some black on posterior lialf of anal fin; a narrow dark curved streak at base of pectoral fin; a dark stripe on cheek and one downward and forward from eye. La Antigna. Named for Hon. Powell Clayton, U. S. Minister to Mexico.

\section{PLELRONECTIDA.}

Etropus crosotus Jordan \& Gilbert.

La Intigua. 3 specimens.

NOTFS ON GEOGRAPHICAL, HATRIBTHON.

\section{Northern Mexico.}

Very little is known concerning the fishes of Sonora and that portion of Chihuahua which lies in the Pacific coast drainage; and while we are not justified in making any generalizations regarling geographical distribution, yet there seem to be a few facts worth mentioning.

Sonora and Western Chihuahua is mostly drained by two large rivers, the Rio Sonora and tha Rio Yaqui: from these two river basins are known at present 16 species of frush water fishes: It from the Rio Vappii and 4 from the Rio Sonora: two species, Catostomus birnartoni and Agrosia chrrsosastir being common to both river basins. From the Gila River in Irizona are known I a species of fishes; of these, two species, Liuclicus niger and Plichochicilus lucurs, lave betn taken in the Rio Sonora, and Agersia chrrsogaster and Pacilia occidentalis in the Rio Yaqui, Agosia chrisosaster being found in all three river basins.

There is a considerable area in Northern Chihuahua west of the Rio Grande and adjacent to the head waters of the Gila River, the Rio Yaqui and the Rio Conchos. Which is drained by 4 small river systems, all of which have no outlets: the Rio Carmen which drains into Layo de I'atos, the Rio Santa Maria which drains into Lago de Santa Maria. the Rio Casas Grandes which drains into Lago de Guzman, and the Rio Castillos which drains into Lago de Castillos. These + basins have not 
been equally explored, though it is likely that all have about the same fauna. From these basins have been taken the following species:

Pantosteus plcbius. Casas Grandes.

Campostoma ornatum. Casas Grandes.

Pimethales confertus. Casas Grandes; Santa Maria.

Leuciscus nigrescens. Casas Grandes: Santa Maria; Carmen; Castillos.

* Votropis santamaria. Santa Marix.

Votropis formosus. Casas Grandes.

- Votropis lutrensis. Casas Grandes; Santa Mariæ; Carmen.

Cyprinodun elegans. Casas Grandes; Santa Mariæ; Carmen.

Of these $\delta$ species none have been recorded from the Gila River or the Rio Sonora. All, except Notropis santamaria and - Votropis formosus, are reported from the head waters of the Rio Yaqui in Chihuahua, and from the Rio Conchos. The.two exceptions are species closely related to Notropis lutrensis, an extremely variable and widely distributed minnow, and which is abundant in the Carmen and Santa Maria rivers. Votropis ornatus is common to both the Rio Conchos and Rio Yaqui, but at present is not known from any of the 4 small river basins. No other species than those here mentioned is known to be common to these two river systems.

Amciurus pricei is a buil-head found in the upper Yaqui Basin. Al large catfish is reported to be found further down the river, which may be the adult of this species.

A large catfish is also reported by the natives to be in the Rio Conchos. It is likely that it is Ameiurus pricei or a closely related species. To find Ameiurus in the Rio Yaqui was unexpected and a little surprising at the time. The genus Ameiurus comprises a large number of species found throughout the Eastern United States, but none are yet definitely recorded from Eastern Mexico, though no doubt one or more species exist there.

Leuciscus nigrescens, Leuciscus purpureus, Leuciscus niger and Leuciscus intermedius are four variable and closely related species. It is barely possible that all may prove to be the same. This fact cannot well be ascertained except by a careful study of a large series of specimens from the different river systems where found.

* Votropis frigidus. Asmall specimen in bad endition froln santa Maria was identitied by Evermann \& fioldsborough as belonging to this species; owiug to their uncertain identification of it 1 omit jt here. 
It is quite evident that the rivers in Sonora have gotten their fauna from the Gila River and the Rio Conchos (or Rio Grande System).

Ptrchocheilus lucius, Agosia crysogaster, Pecilia oicidentalis, Leuciscus niger and Gila minace have probably migrated or resulted from migrations from the Gila River.

Mr. John P. Ramsey of El Paso, Tex., tells me that trout aro found in Chihuahua on the west slope of the Sierra Madre mountains. 'The specie's is not known. As no trout are known from the Gila River it is quite safe to predict that this species is Salmo clarki pleuriticus or a closely related species.

Pantostus plibius, Leuciscus nigrescens and Leuciscus purpureus are apparently equally related to the fauna of the Rio Grande and the Gila River, leaving 8 species which have migrated or resulted from migrations from the Rio Grande system. Of the 4 species known from the Rio Sonora, 3 belong to the Gila River.

The fishes of Sonora and of that portion of Chihuahua which belongs to the Pacific slope, are migrants from the Rio Grande and the Gila River, the greater number from the former. W'hen and how this migration occurred can be discovered only by a careful study of the topography and geology of this region. It evidently took place within recent geological times.

\section{Southern Mexico.}

There are at present io species of fishes recorded from the valley of Mexico:

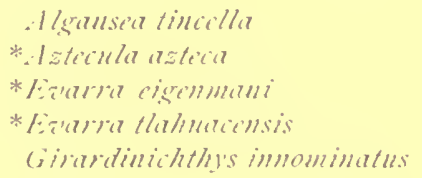

Zoosoneticus miniatus
*. Yivffia a'driegatas
Chirostoma jordani
Chirostoma humboldtianum
Chirostoma ostor.

Four species (marked*) have so far not been found elsewhere. All of the other species belong to the Rio Lerma fauna. One species Algansea tincella, has been found in the Rio Moctezuma. an upper tributary to the Rio Panuca. Astecnla mexicana has been taken only in the Rio Moctezuma, and Astecula lerme only in Lake Lerma, near the head waters of the Rio Lerma. These two species are very closely related to Astecula asteca. Of the three species taken in the Rio Moctezuma. one species, Algansea tincella, is found in the Rio Lerma and in the Valley of Mexico. A second species, Gooter caliente, is found in the Rio Lerma. Astecula mivicam, the third, is found in neither of these 
basins, but in each it has a near relative. The faunas of the Valley of Mexico, the Rio Moctezuma near its source, and the Lerma Basin are practically the same. Jordan and Snyder examined the Rio Verde, a tributary of the Rio Panuca, near Rascon, San Louis Potosi; none of the species taken there have been taken in either the Valley of Mexico or the Rio Moctezuma at San Juan del Rio, or the Rio Lerma, all of which have practically the same fauna, and one peculiarly characteristic of this region. Ten of the I $S$ genera known from the Lerma Basin have no representatives yet known from other waters. Chirostoma has not been taken in the adjacent water systems. Characodon is represented in Southern Mexico, Centrai America, and Lower California. Gambusia comprises a number of small viviparous fishes usually inhabiting swamps and springs all the way from Southern Illinois to Panama. The other five genera, Lampetra, Ameiurus, Moxostoma, Notropis and Hybopsis are northern genera, and all except $N$ otropis are not represented by any species farther south than the Rio Lerma.

Of the 46 species found in this region, 30 belong to two families; 6 to Pacilizde and It to Athermida. It is curious to note here that all of the Paciliida are viviparous, and only one species, Gambusia infans, has the anal fin of the male placed well forward and modified into an intromittent organ such as is characteristic of Heterandia, Pacilia and the like. In the other 5 species the anal fin of the male has its normal position and size. It is slightly modified by the shortening of the first five or six rays. and their slight separation from the rest of the fin by a shallow notch. Just what part this fin plays in fertilizing the eggs in the body of the female is not known. It evidently plays a prominent part in this operation.

The spawning time for these fishes is near the close of the dry season. At this time the water is more concentrated, as is also the food on which the young must feed. The aquatic insects, crustaceans and small fishes which would feast on the eggs if deposited then are also more concentrated, so that depositing eggs at this time would mean considerable destruction to the species. Is it is. the young are born in a well developed stage, and have time to reach some size before the wet season sets in. They are then, perhaps, in the best condition to becone widely distributed as the volume and area of water increases. As the dry season approaches again, and small streams and ponds become dry, many of these small 
fishes perish. 'They are, however, present everywhere to establish themselves in every body of water which may carry them through to the next rainy season.

The larger number of the Precilizde are mud-eating fishes. A few, such as Zoogonticus, are carnivorous.

The gestation of many tropical fishes present some strange peculiarities. Some of the Siluride carry the eggs in the mouth till hatched, while a few others are thought to be viviparous. Viviparity among the tropical Pacilita seems to be the rule rather than the exception. It would seem that in the tropical fresh waters of America, there is much more provision made for the care of the young than in the cooler waters of the Northern continent.

It was rather surprising to find such a large number of Chirustoma in the Lerma Basin and the probability is that this number will be considerably increased when this basin is more thoroughly explored. I had seen but a few specimens of Chirostoma before going to Mexico, and so never had an opportunity to study these fishes. Ind while I was careful to pick up specimens of all species. yet my unfamiliarity with the group, no doubt. caused me to overlook some species. Again there is a number of small isolated lakes which have never been visited. Most of these lakes. no doubt, as do Patzcuaro and Zirahuen, have in them one or more characteristic species. This river system is far from being thoroughly explored. While its species are about onethird the number of those found in the Wabash River in Indiana, its fish fanna is quite as distinct and characteristic as if it were an island in the sea. Considering this basin as a whole, taking note of its spring brooks and running waters and its sluggish streams; its lakes, some with outlets, others without outlets; some fresh, others quite brackish: its interesting and peculiar fish fauna is certainly inviting to the student engaged in the study of variation.

The Rio Balsas is one of the largest rivers in Mexico. It is southeast of the Lerma and drains about the same area; and though these two rivers are so near eachother, not a single species of fish is known to be common to both. At present but ten species are known from the Balsas Basin. But one species of the Atherinile and two of the Precilide, are known from the Balsas, and yet these two families comprise nearly two-thirds of the fishes of the Lerma Basin. The Balsas is far from being thoroughly explored; 
still enough has been done to indicate the fact that it contains comparatively few species of fishes.

The Rio Verde, a small stream considerably south and east of the Rio Balsas, was examined at Oaxaca, and only two species of fishes, Heterandia lutzi and Fundulus oaxaca, were taken from it; neither of these are found in the Balsas.

The Rio Quiotepec has two species of fishes in common with the Rio Balsas, Tetragonopterus mexicanus and Agonostomus nasutus. The latter species, together with Pacilia limantouri, is also found in the Rio Balsas and the Rio San Francisco at La Antigua. The rivers south of Mexico City on both sides of the divide have much more in common as to their faunas. than any of them have with the Valley of Mexico and the Lerma.

Evermann and Goldsborough call attention to some small dried specimens of fishes purchased in the markets of Yautepec, Morelos. These specimens appear to be Chirostoma jordani. It is likely these fishes were sent to these markets from Mexico City or some point in the Lerma Basin. I do not believe they were obtained in the Balsas Basin.

The Leuciscus nigrescens recorded by B. A. Bean from Lago de Quitzeo, has since been identified by him as Algansea tincella. There is some doubt as to whether the type of Algansea sallei really came from Cuernavaca. Neither Jordan, Snyder nor myself found any species of this genus in the Rio Balsas Basin; and from the fact that the faunas of the Rio Lerma and Rio Balsas are so unlike, I doubt if this species occurs in the latter.

Tetragonopterus mexicanus is, I believe, wrongly ascribed by Fillipe to the Valley of Mexico. Mr. Woolman records Campostoma ornatum from Salamanco in the Lerma Basin. It is likely his specimen really came from Chihuahua.

SUMMARI.

The fish fauna of northern Mexico is essentially that of the Rocky Mountains and Eastern United States, or that part of the United States adjacent to Mexico. The Eastern fauna has crowded its way over the divide and has become even more firmly established in the Pacific coast streams of Sonora than has the Rocky Mountain fauna.

The South and Central American faunas prevail largely as far north as the City of Mexico. The few forms which extend farther 
north apparently keep to the lowland streams; especially is this true on the Pacific side. The most northern representative of the South American fauna, one of the Cichlida, is found at Mazatlan. On the east coast this family has a representative in. Texas. The fauna of the Lerma, the only river basin extensively studied, is quite distinct from either North or Central and South America. This fauna is richer and more characteristic than was formerly supposed. Almost nothing is known concerning the fishes between the Rio Lerma, the Rio Yaqui and the Rio Grande. An examination of the fauna of the Rio Nazas and other rivers in Central Mexico whose waters never reach either ocean would be extremely interesting. For a study of geographical distribution the fresh water fishes of Mexico are very interesting, perhaps more so than any other animals distributed over a like area. 


$$
\text { D }
$$


UBRARY

(f) THE

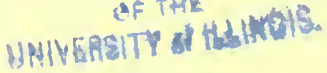




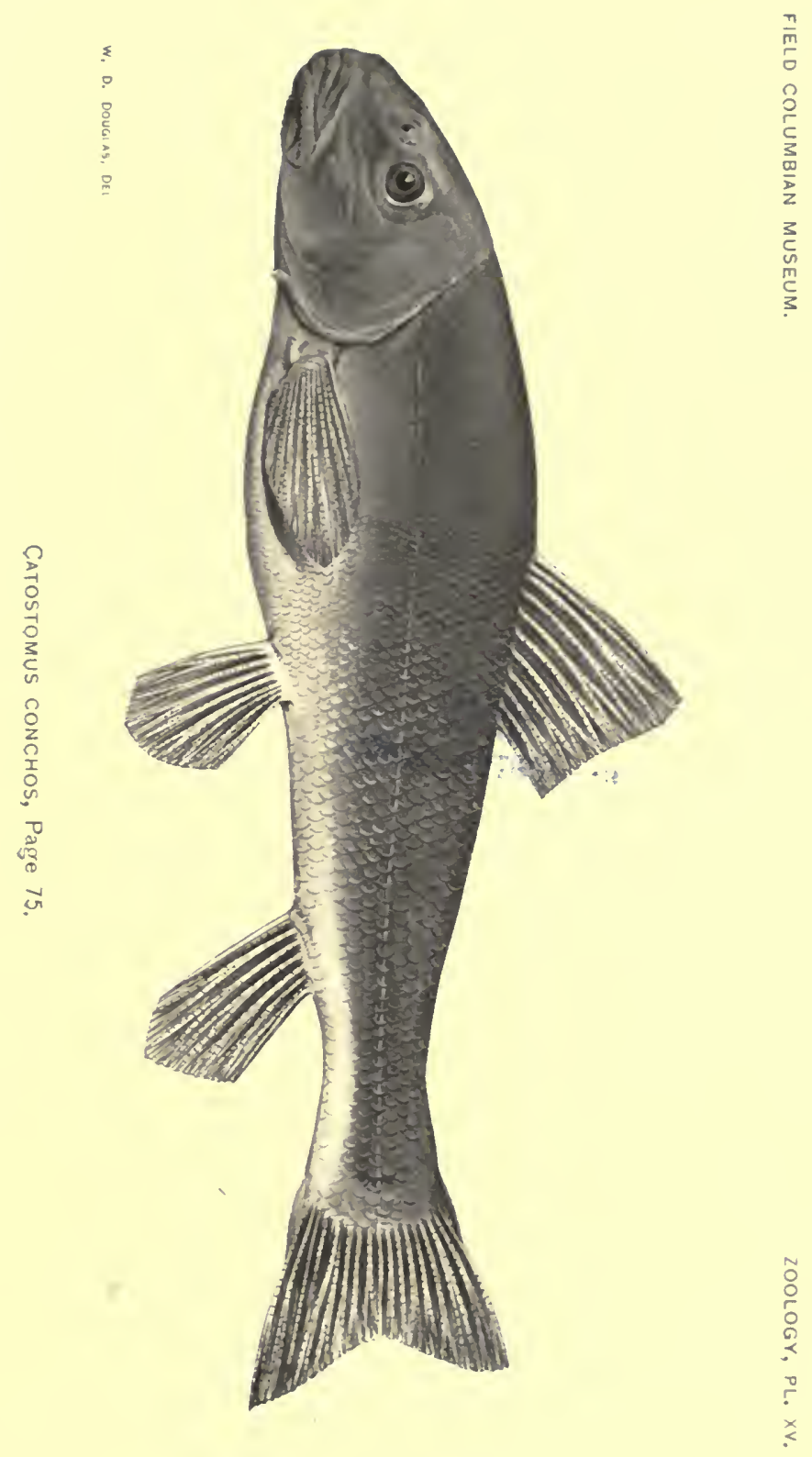


IJPRARTY

OF TME UHY EROTY H HLHNOIS 


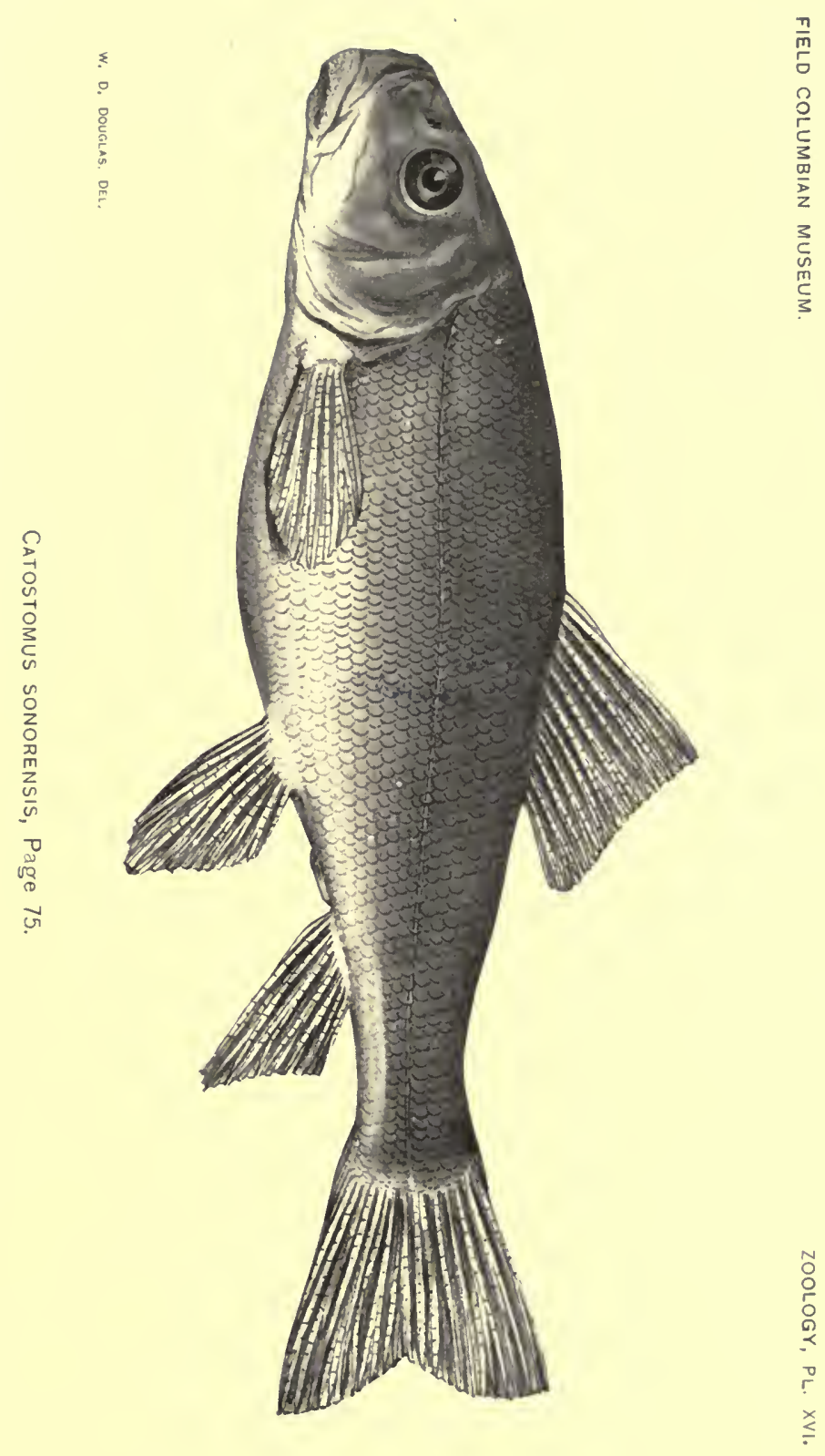




\section{UBRARY}

AF THE UFHERQTY of HLINOS. 
LIBRATY

OF TME

UNIYGRETY HLWOIS 


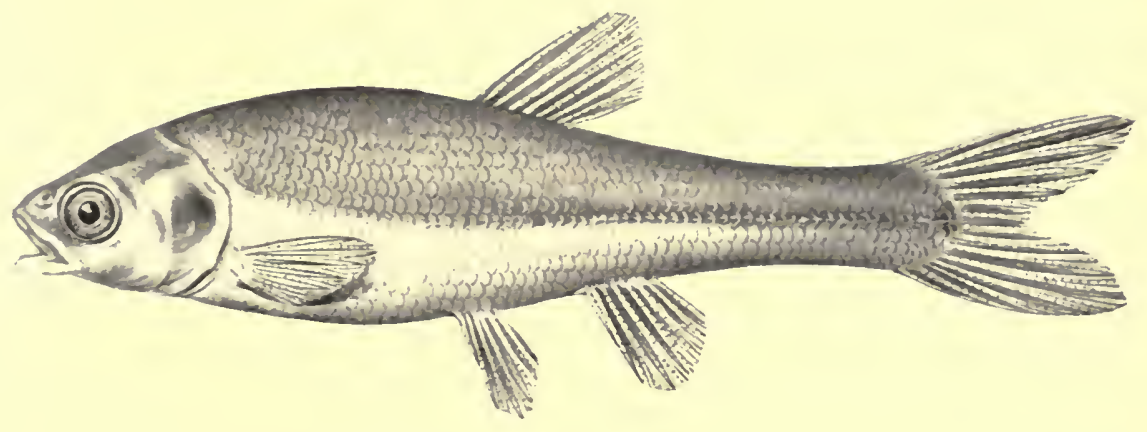

aztecula mexicana, Page 81.

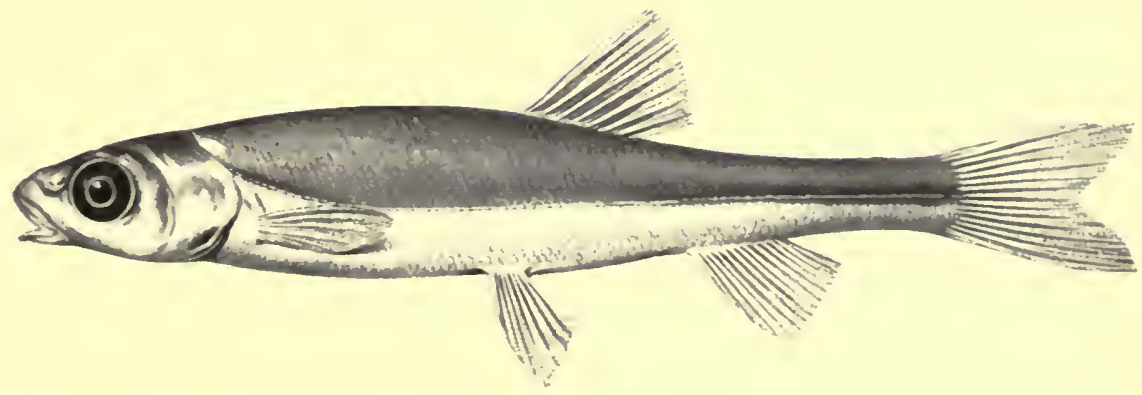

W. D DOUGLAS DEL.

Evarra tlahuacensis, Page 85. 
CF THE

UNIYERETY a RLMOIS 


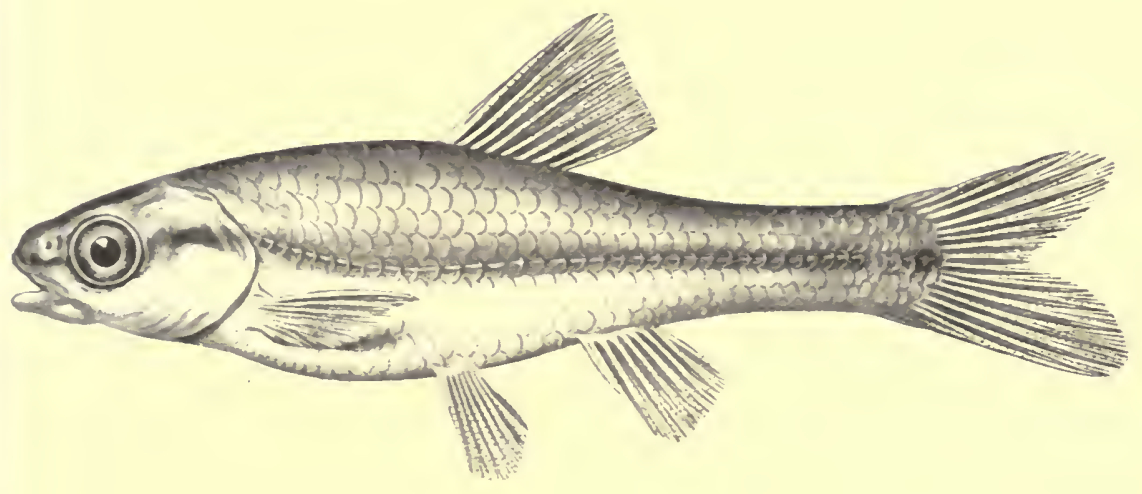

w D. COuGass. DE.

NOtROFIS ROBUStUS, Page 82.

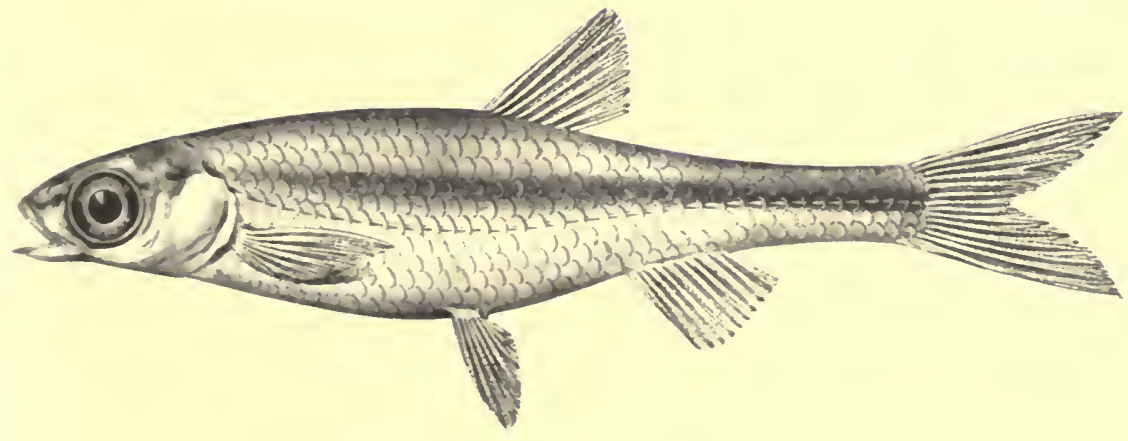

w. D. Doukas De.

Notropis santarosalie, Page 85. 
LUBRARY

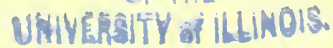




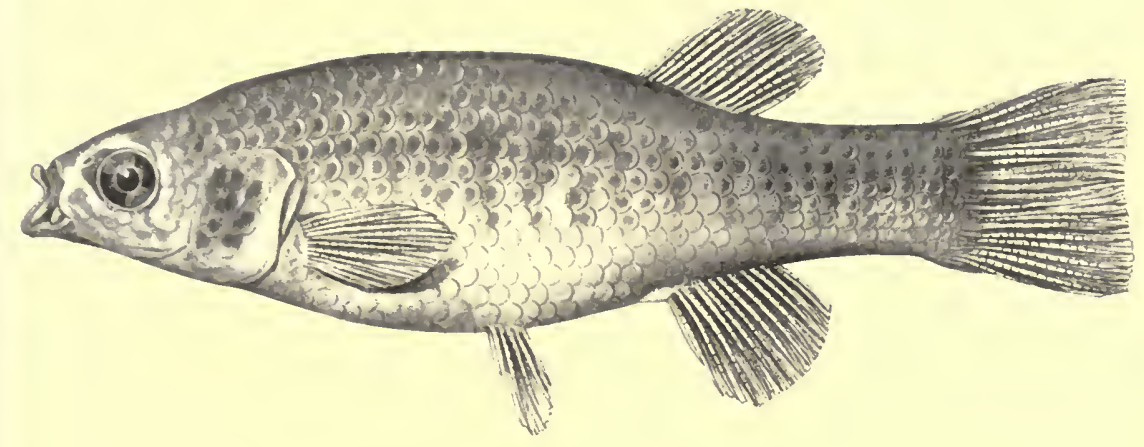

W. D. Douglas, del

Fundulus oaxace, Page 90.

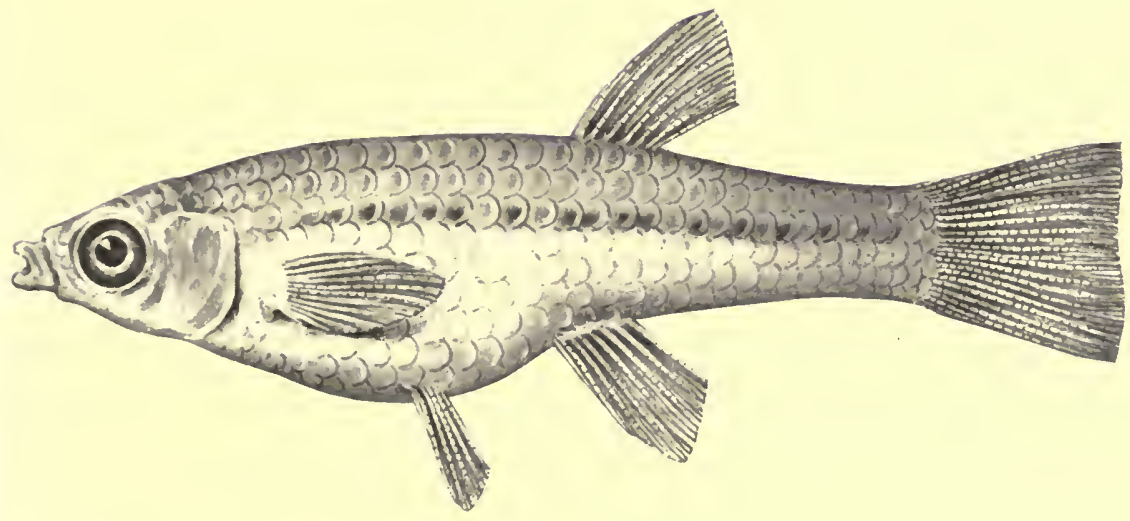

W. D. DOUGLAS. DEL.

Heterandia lutzi, $q$, Page 106. 


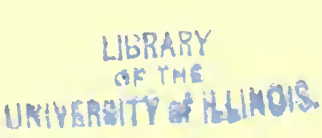




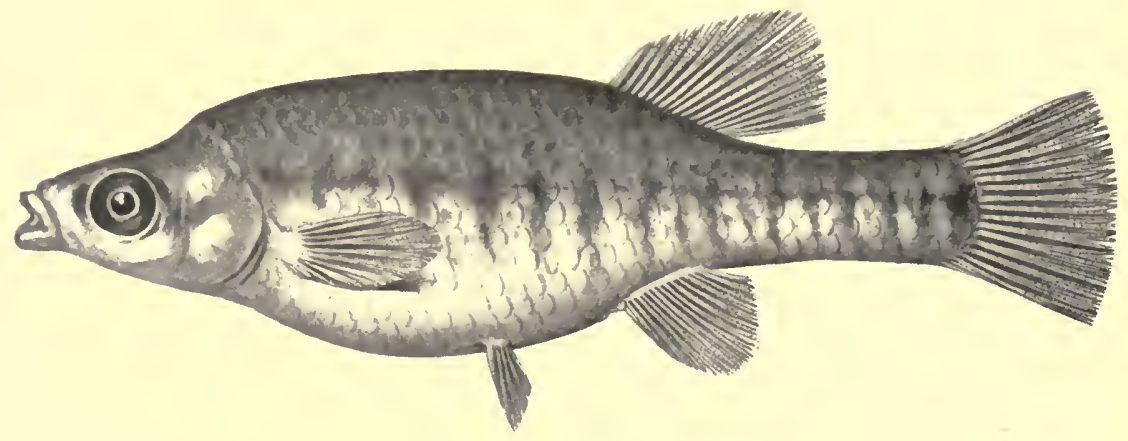

w. D. Djuglas. oel

Zoogoneticus diazi, $q$, Page 93.
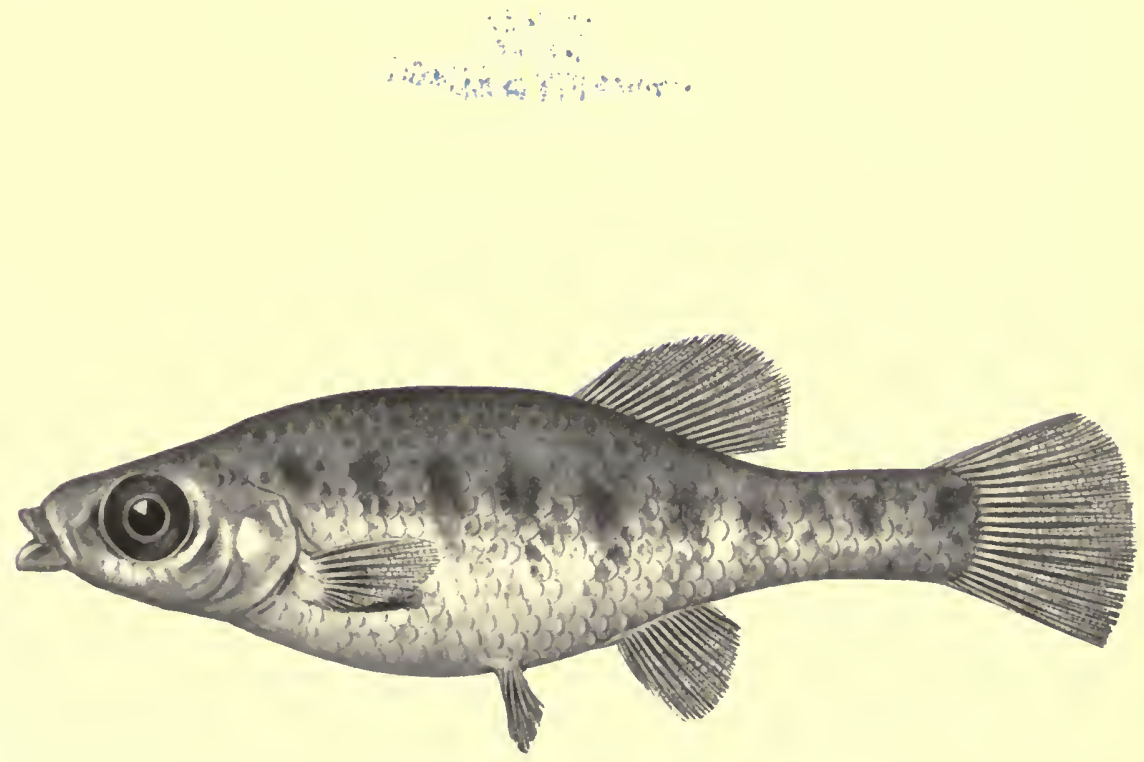

W. D. DOUGLAS, DEL.

Zoogoneticus mineatus, $q$, Page 94. 



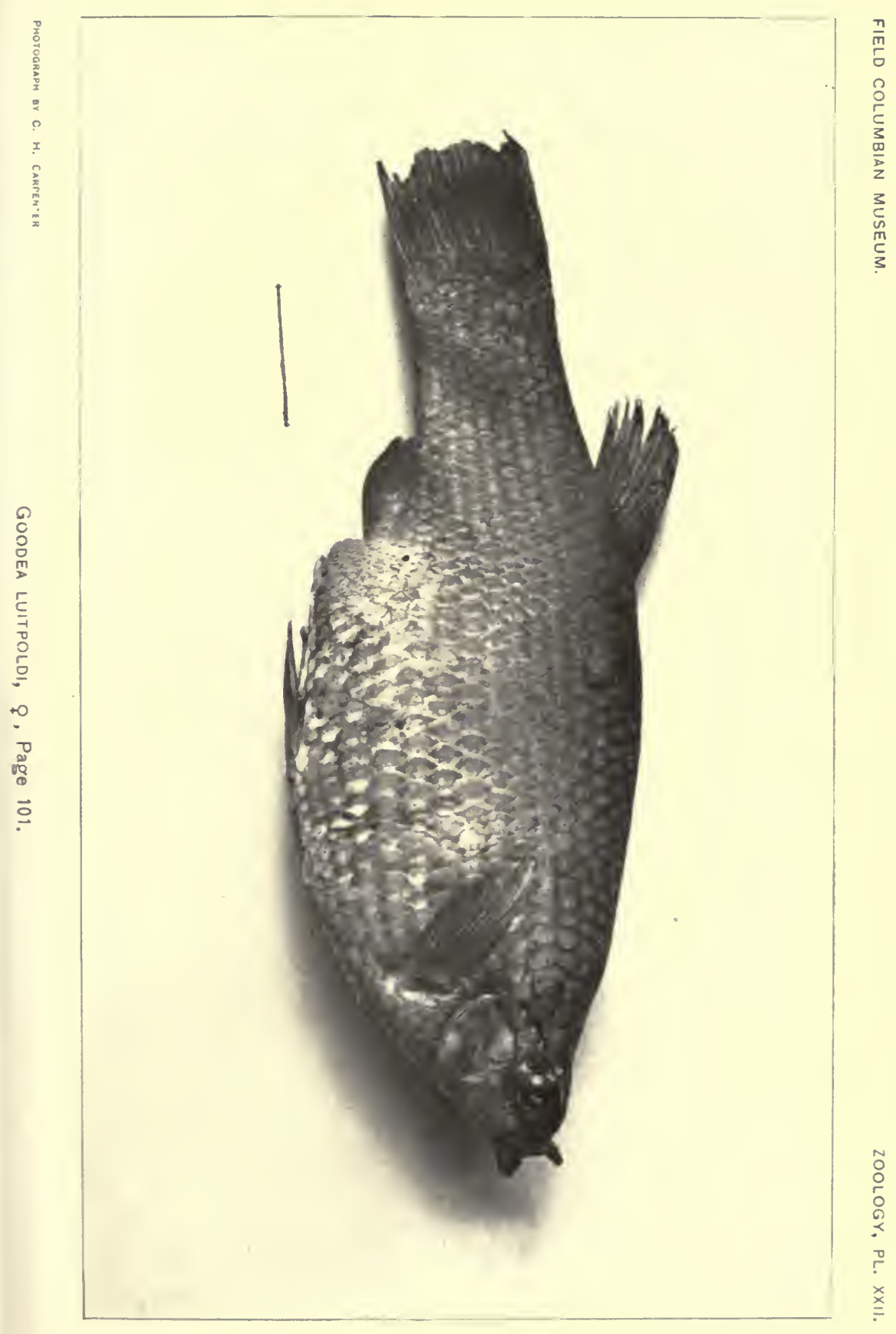


LERARY

OF THE

UKIVERATY of LUITOS 


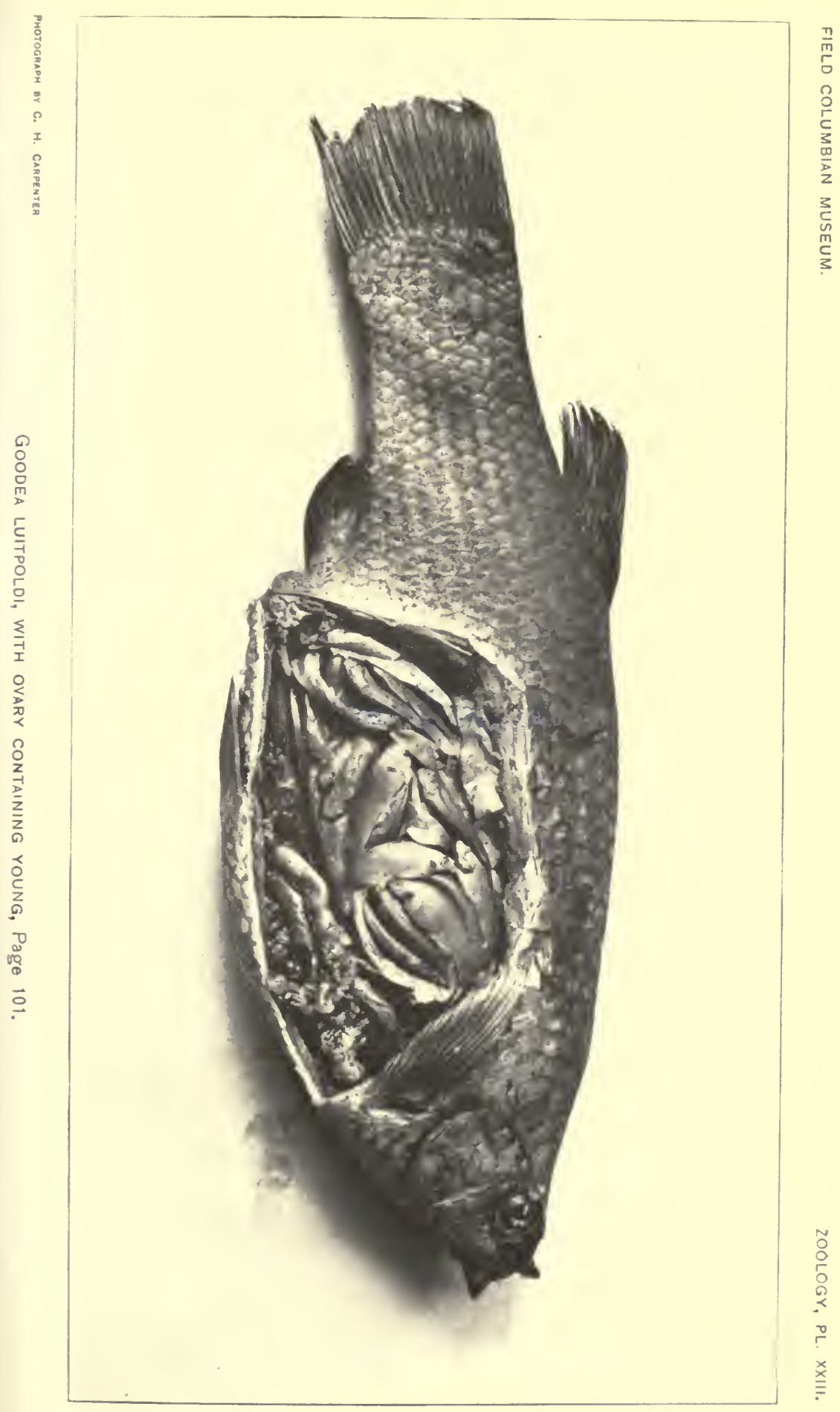




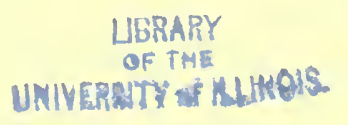


1

LIBFAPY

UNAERS THE

of 3 Livols 


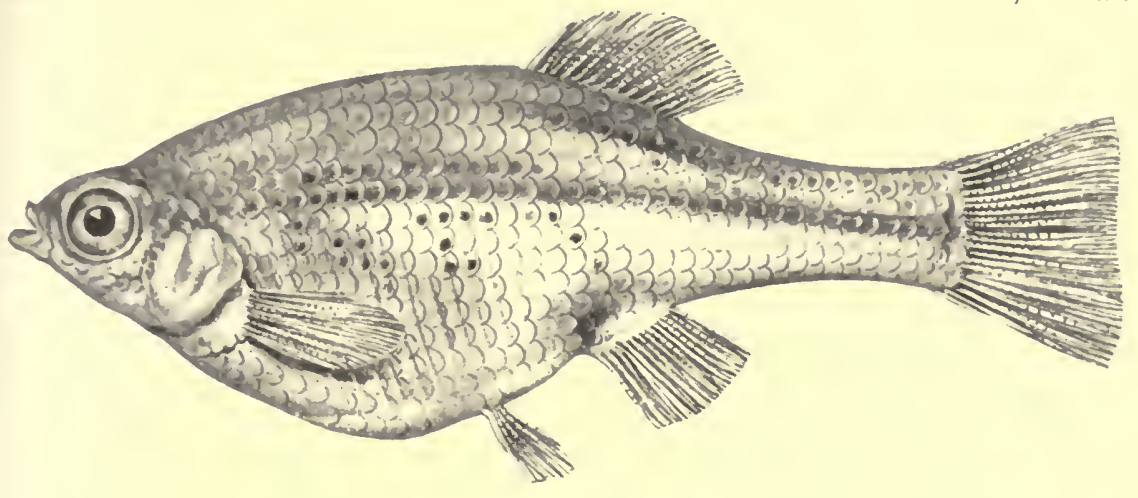

w. D. DOUGLAF, DEL.

SkiffiA LERMe, $q$, Page 102.

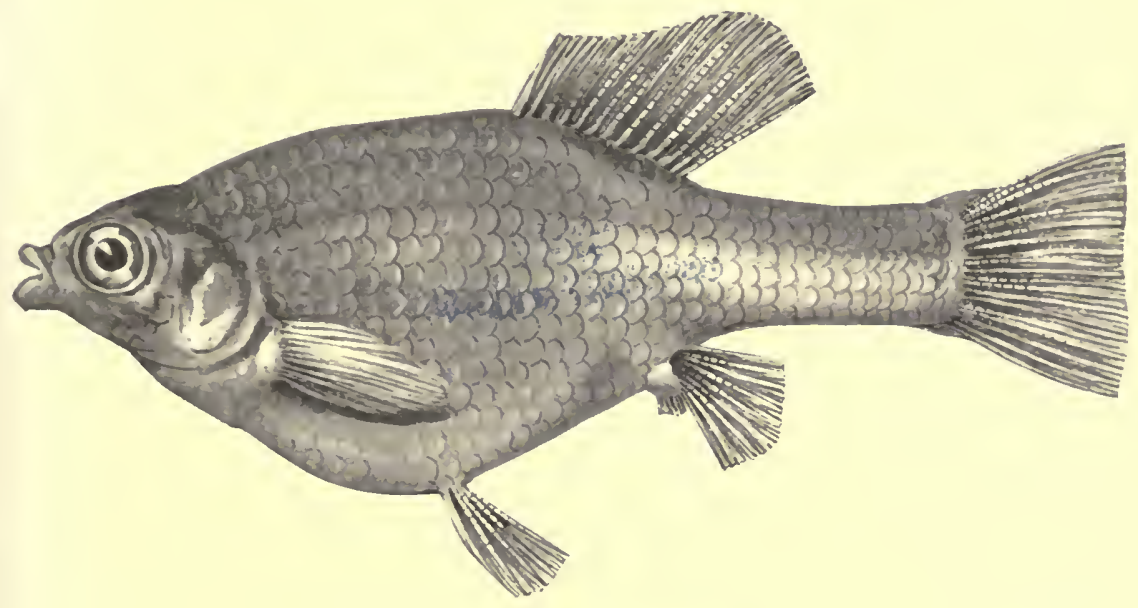

W. D. DOUG:A5 DE

SK FFIA LERME, $\delta$, Page 102.

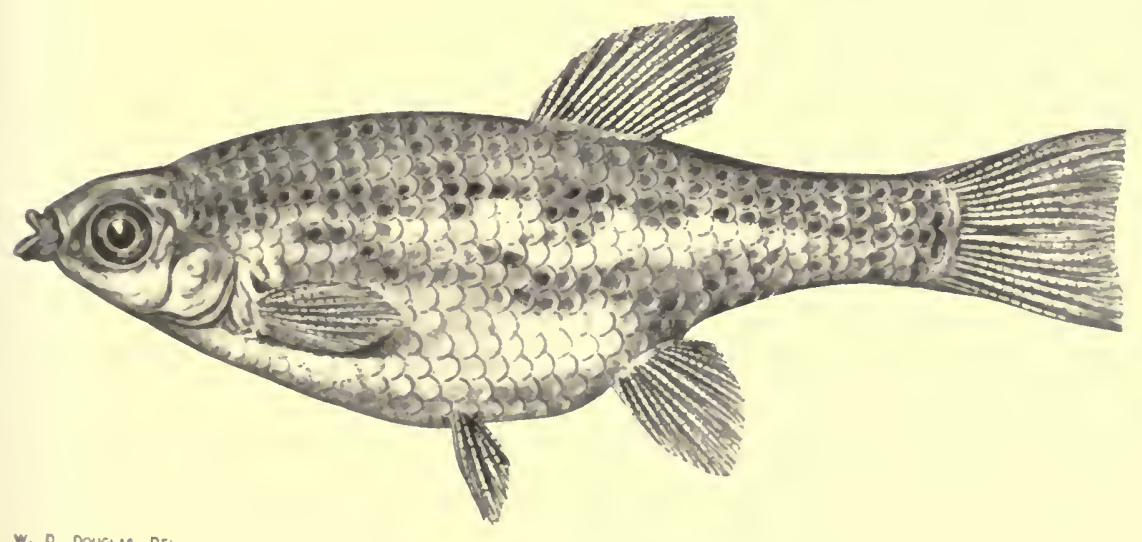

SKIFFIA VARIEGATA, \&. Page 10: 
USRARY

OF TME

UAHYEATTY HUWCS. 


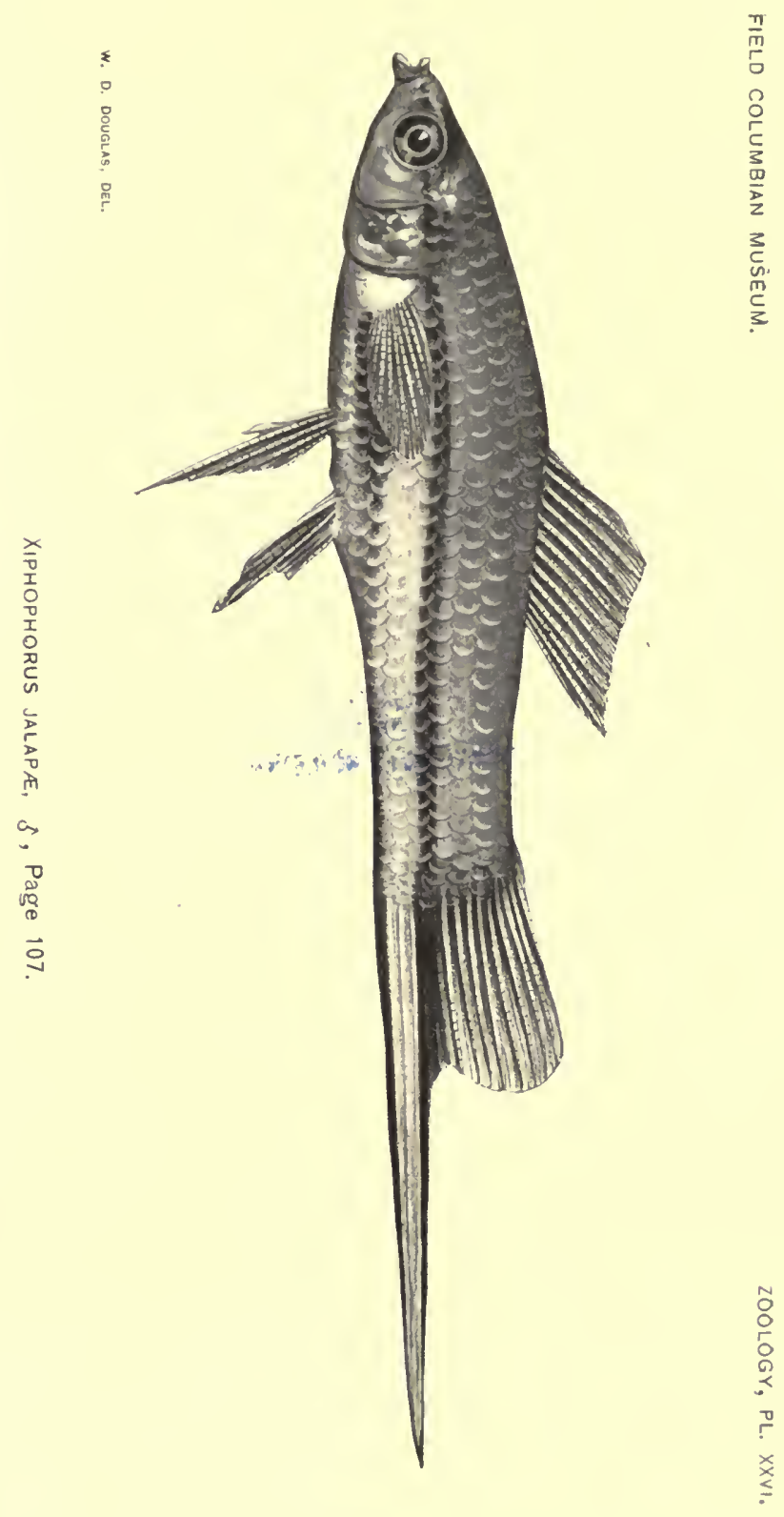


LIBRARY

OF THE

UNIYEFSITY W ILUINOIS. 


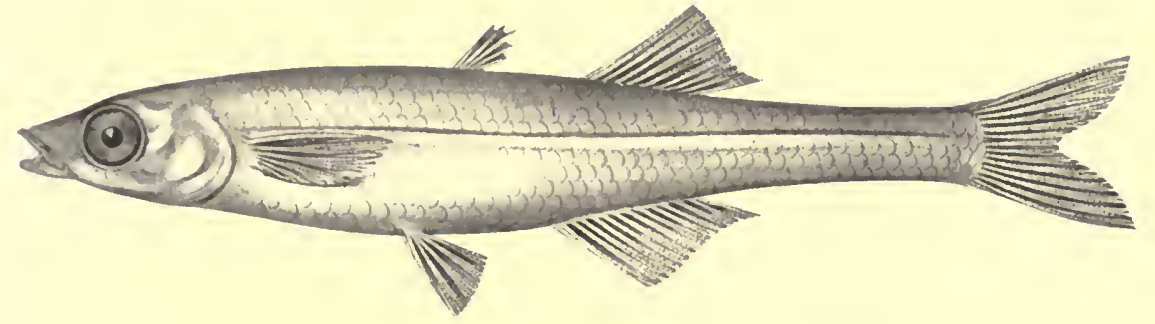

W. D. DOUGLAS, DEL.

Chirostoma attenuatum, Page 112.

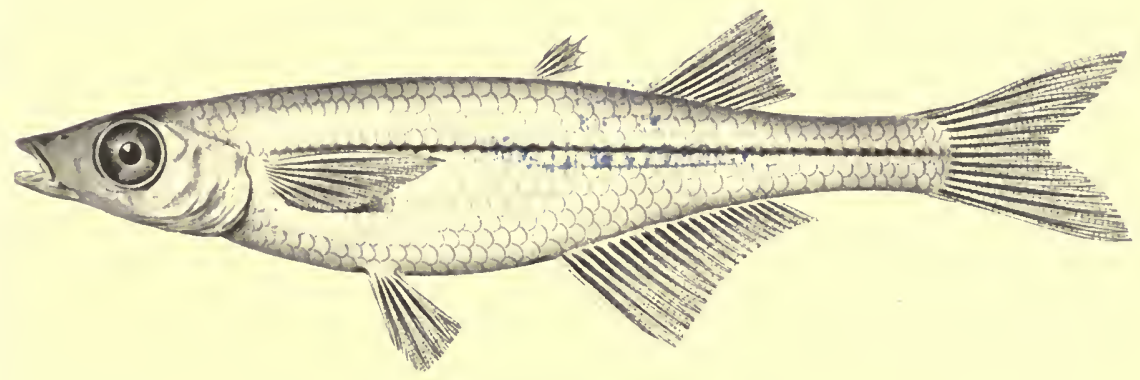

w. D. Douglas Del.

Chirostoma labarce, Page 113.

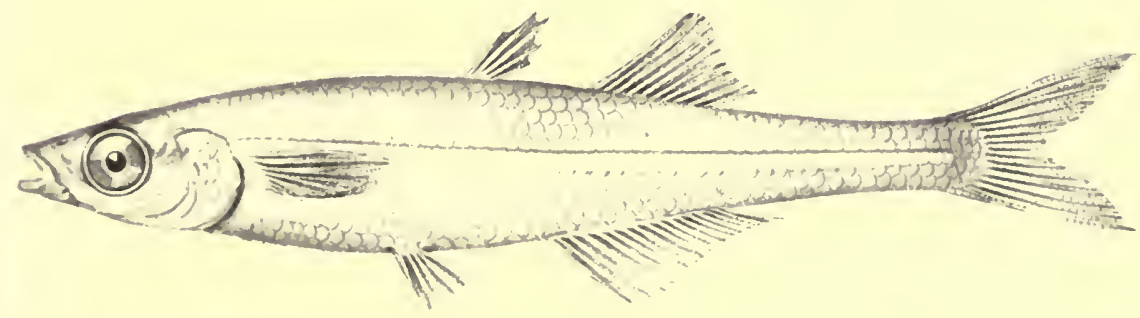

W. D. DOUGLAS OEL

Chirostoma patzcuaro, Page 113. 
LUBRARY

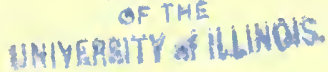




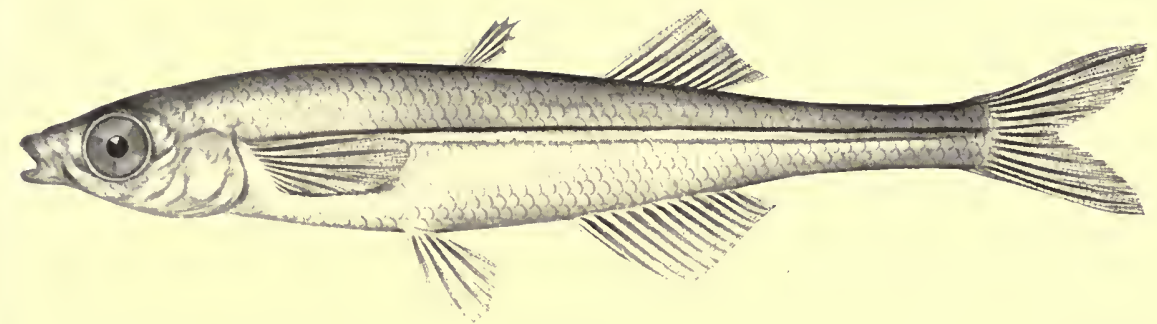

W. D. DOUglas, Det.

Chirostoma zirahuen, Page 114.

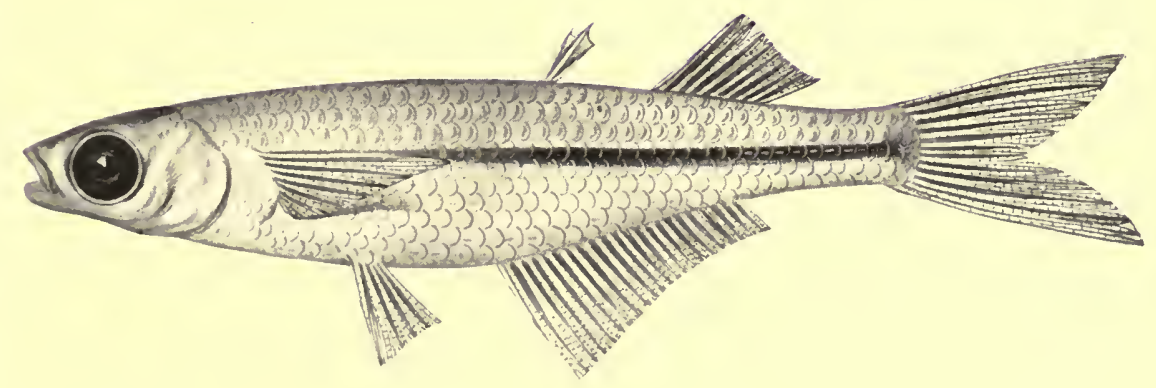

W. D. DOUGLAS, DEL.

MELANIRIS balsanus, Page 117. 


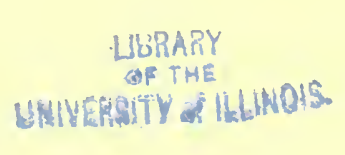




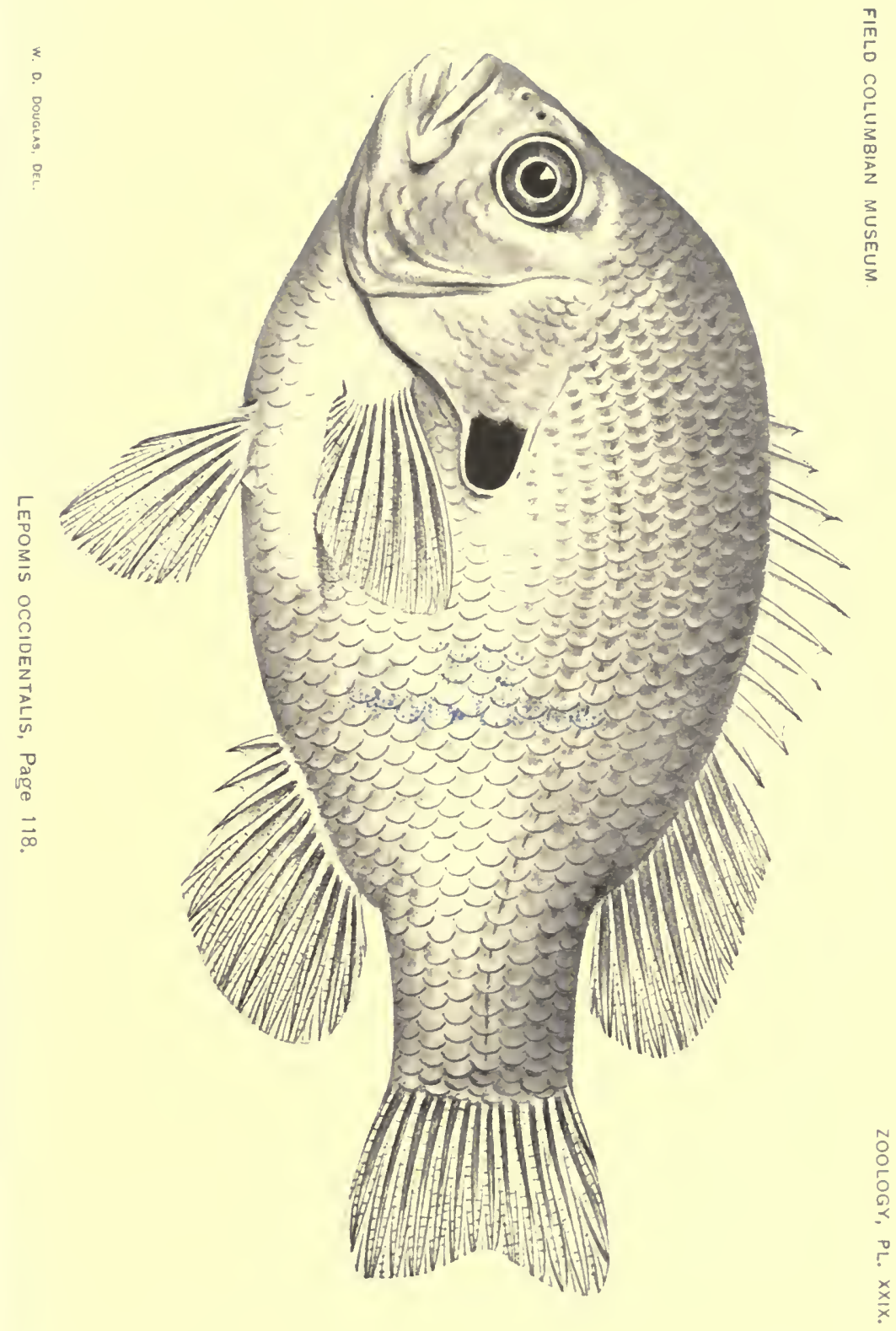





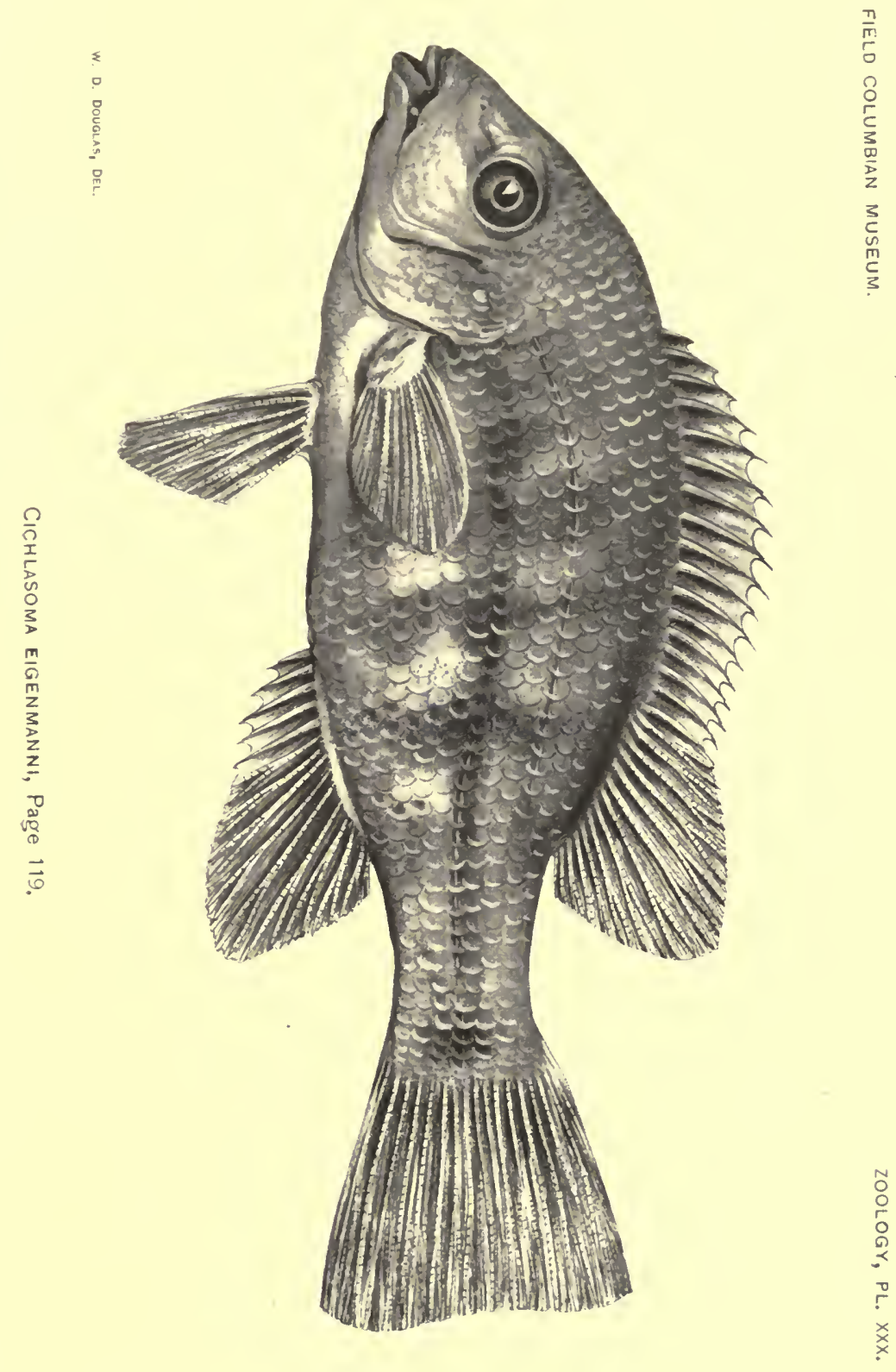




$$
\begin{aligned}
& \text { LWRARY } \\
& \text { OF THE }
\end{aligned}
$$

UNIYERSITY OLLINOIS. 


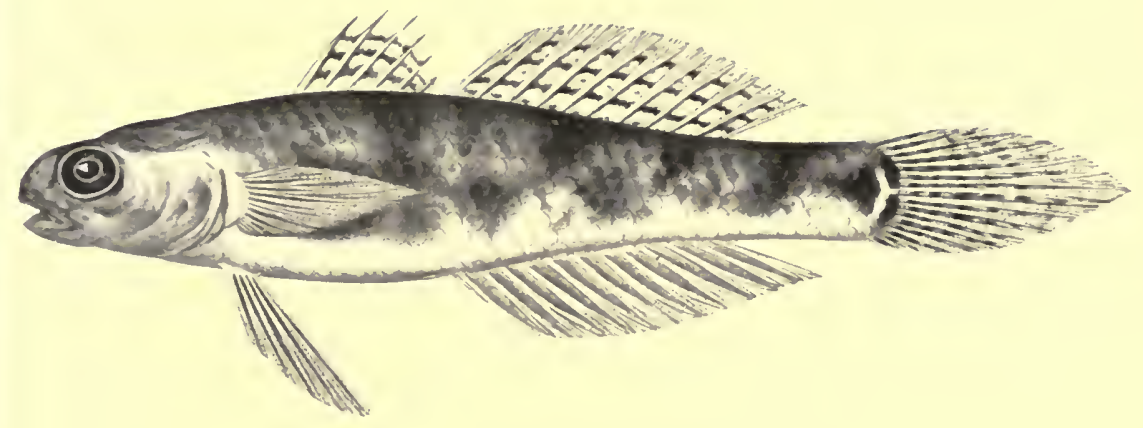

W. D. DOUGLAs, DEL.

Gobius PaRVuS, Page 121.

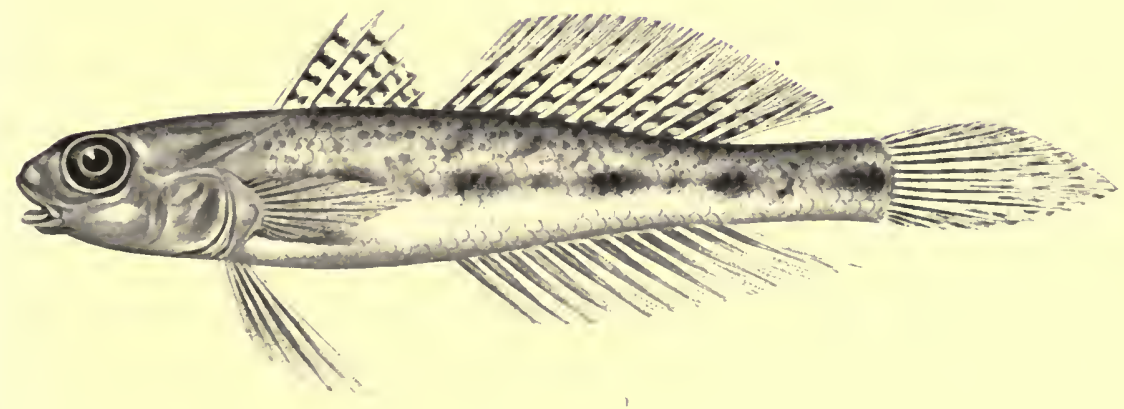

W D. DOUGLAS, DEL

Gobius Clayton!, Page 121. 
Git 1

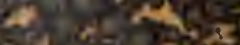

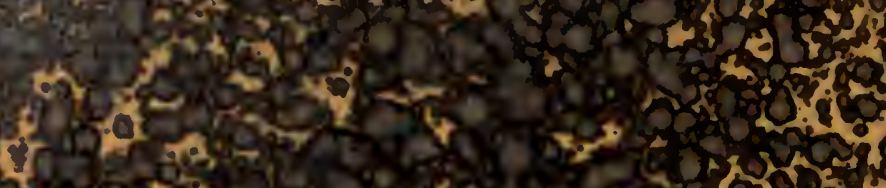

is.

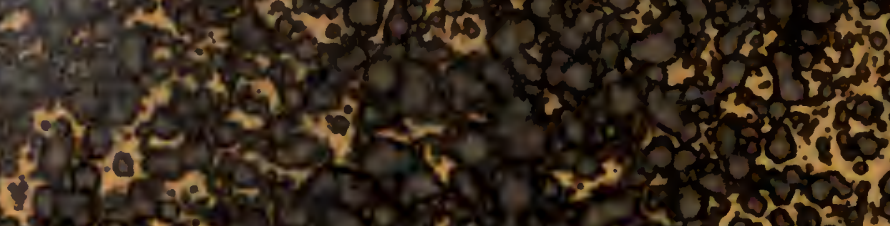

7.

85

59

x $x+50$

(x)

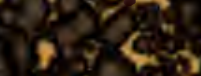

(s)

on

8. 5 .

is:

anivios

Tha 1 :

3

is.

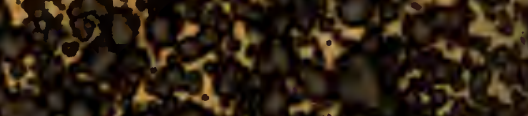

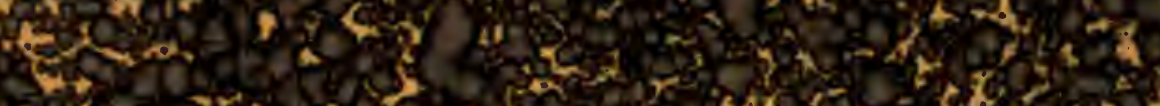

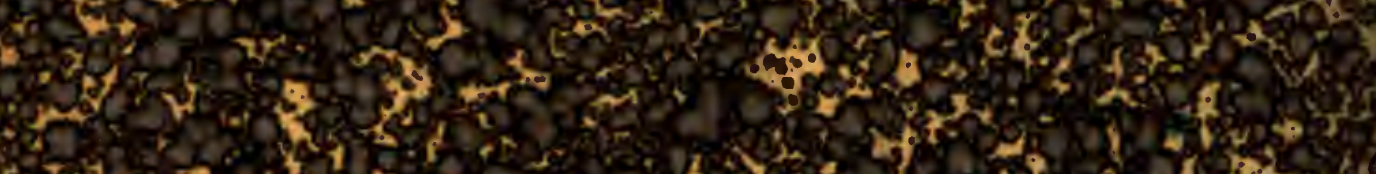

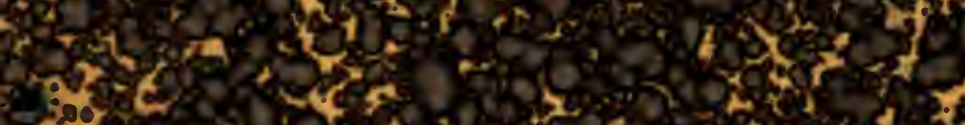

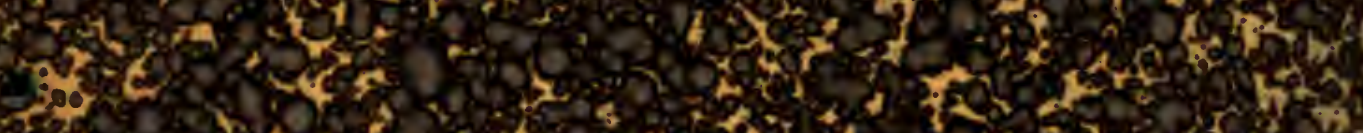

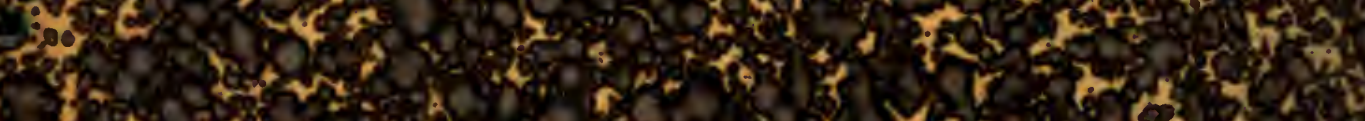

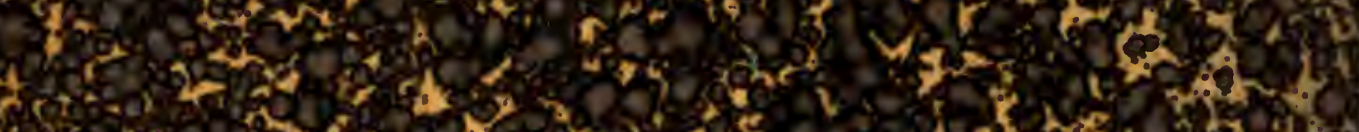

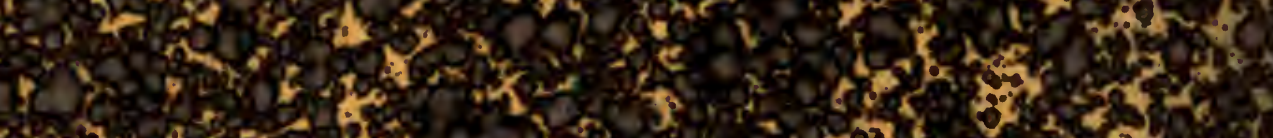

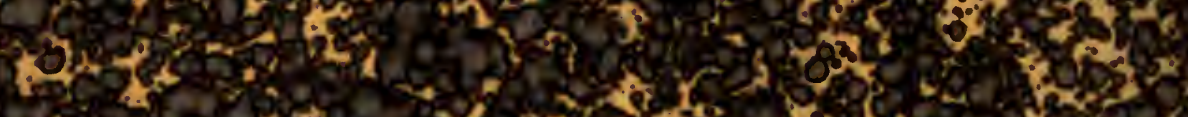
61

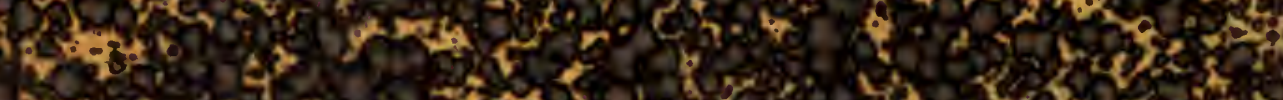

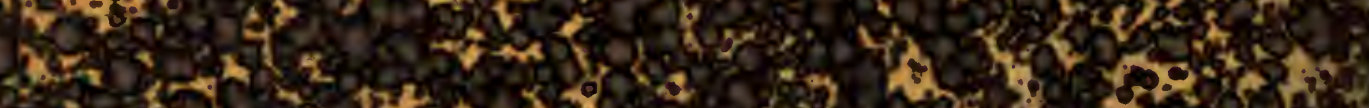

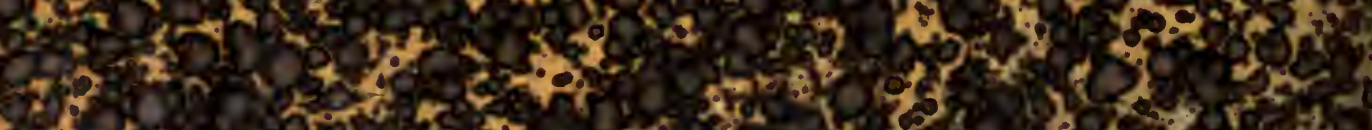

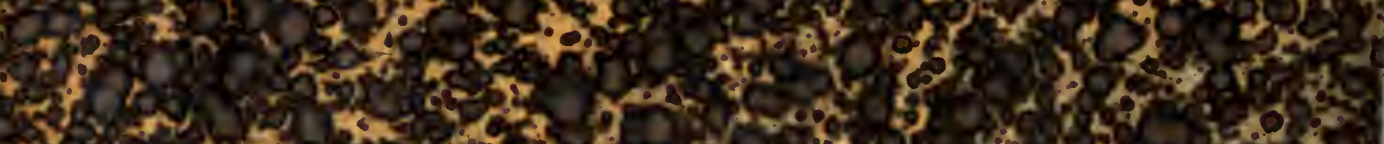

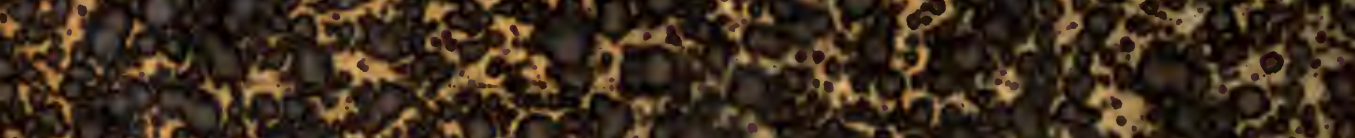

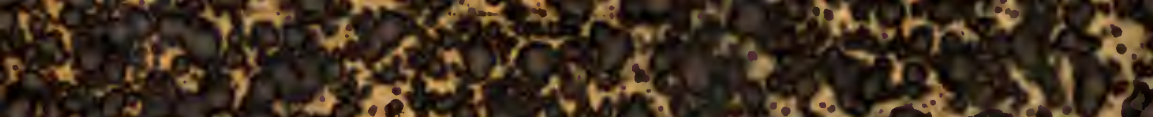

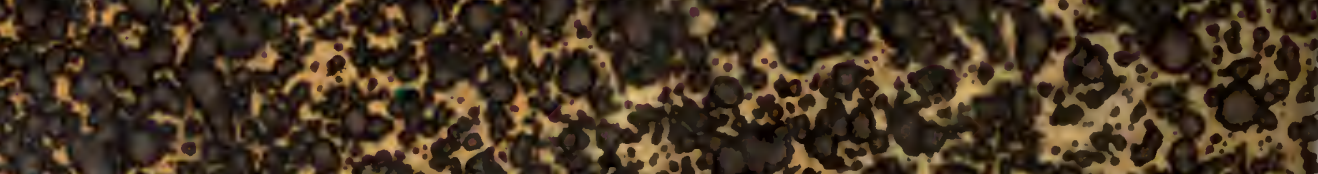
Qriess (3)

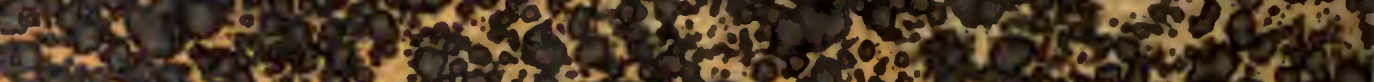

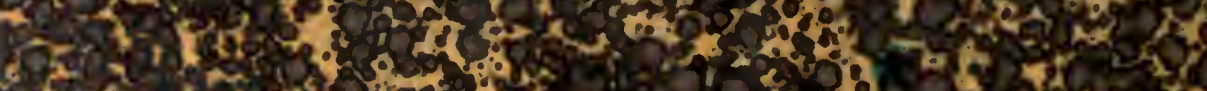
$\left\{\begin{array}{l}5 \\ 5\end{array}\right.$

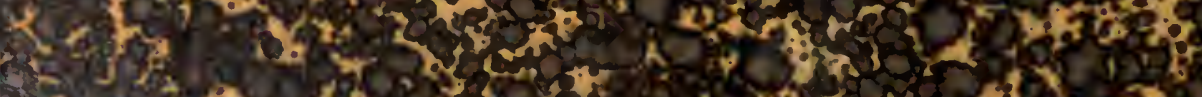

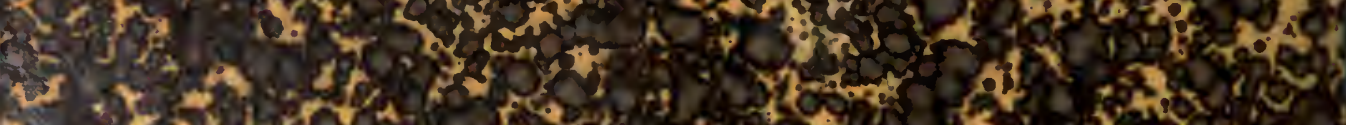

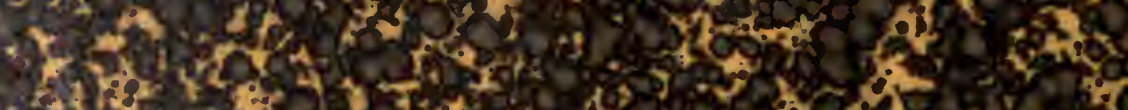

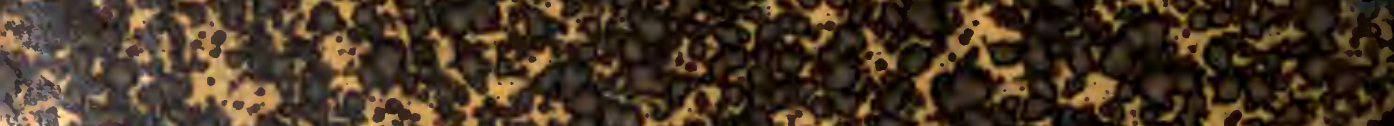
Whar 3 -

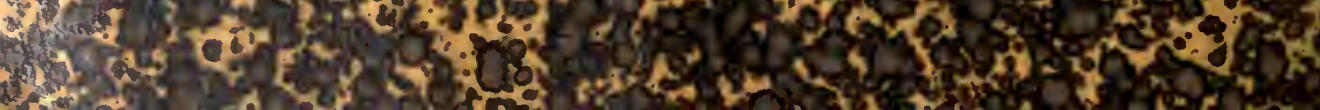




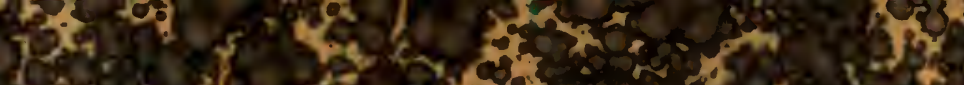




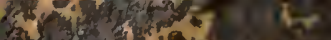

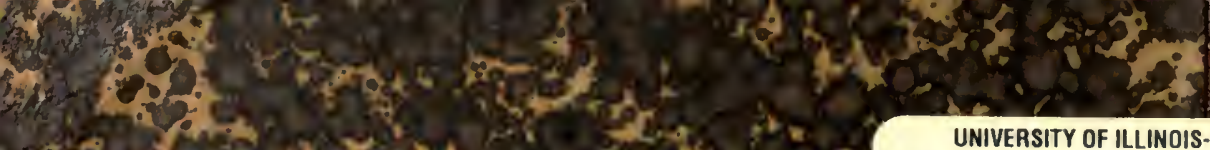

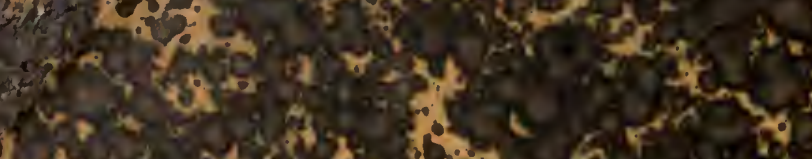

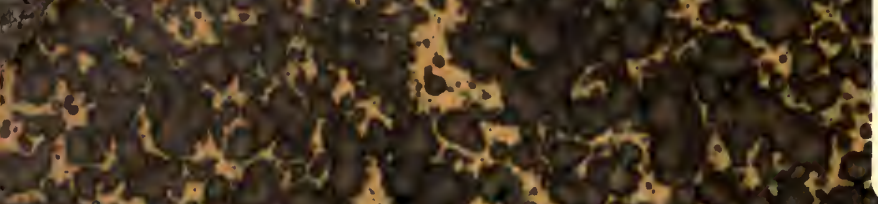
W $8 x^{4}$ $590.5 \mathrm{FI}$

UNIVERSITY OF ILLINOIS-URBANA

FIELDIANA, Z0OLOGYSCHGO

3 1900-04

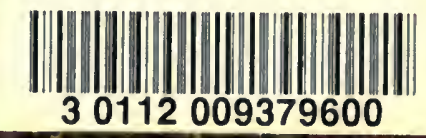

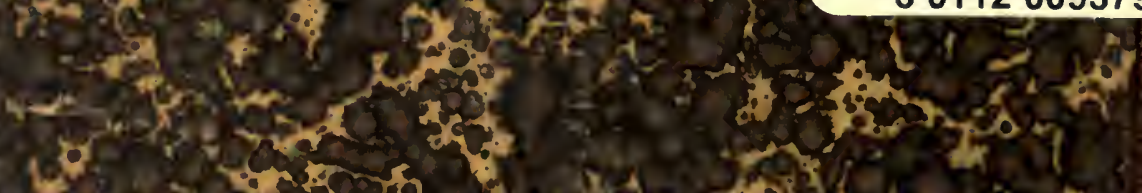
2.

H. W

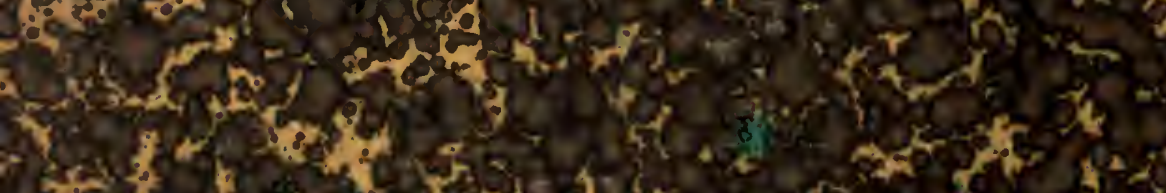

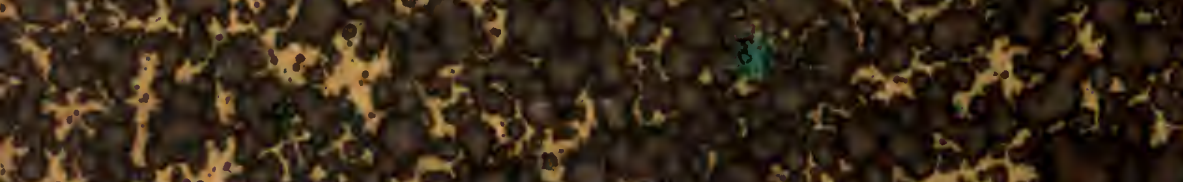

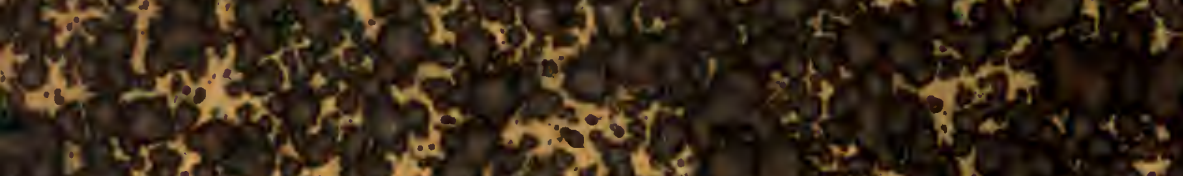

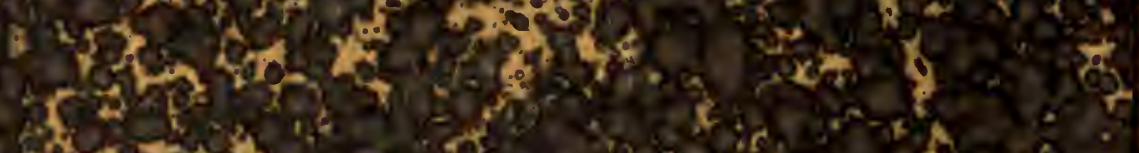

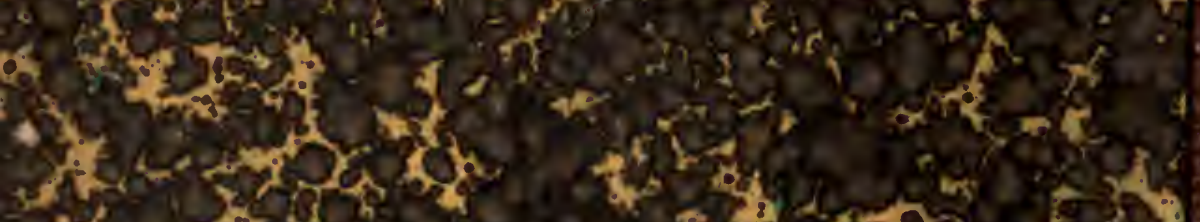

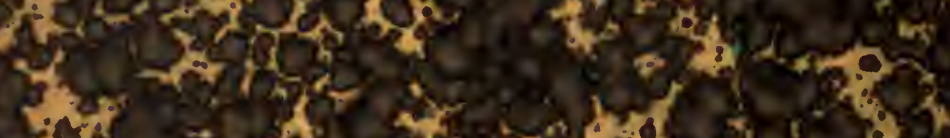

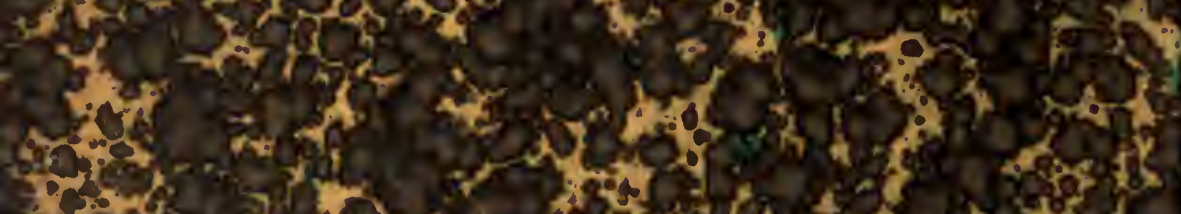

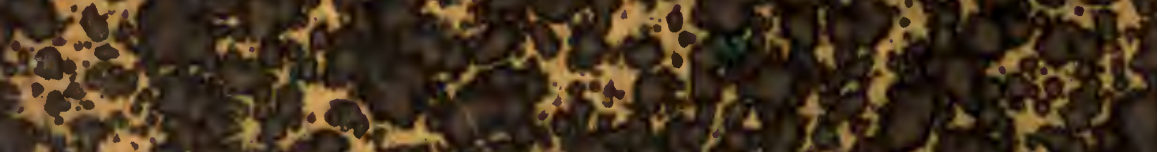

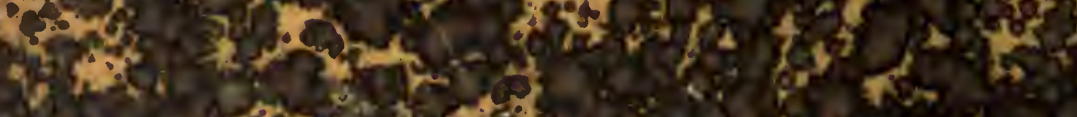

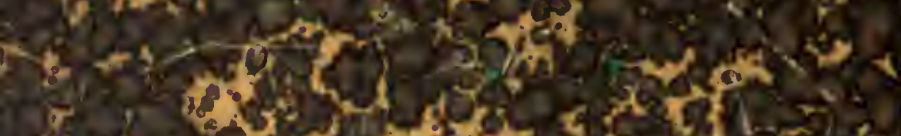

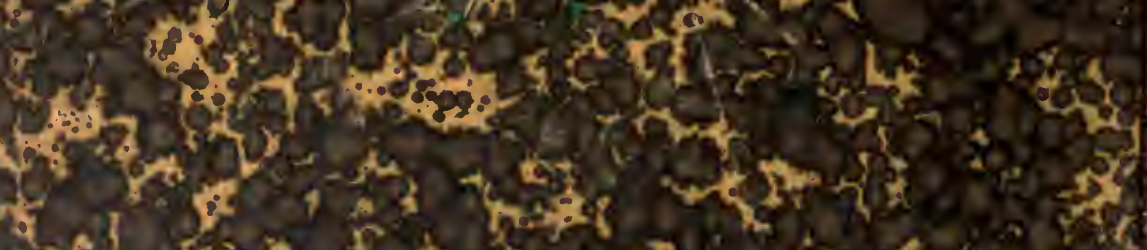

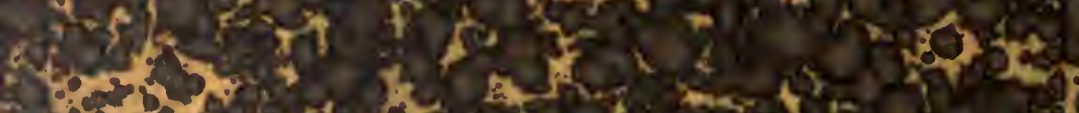
try w Q

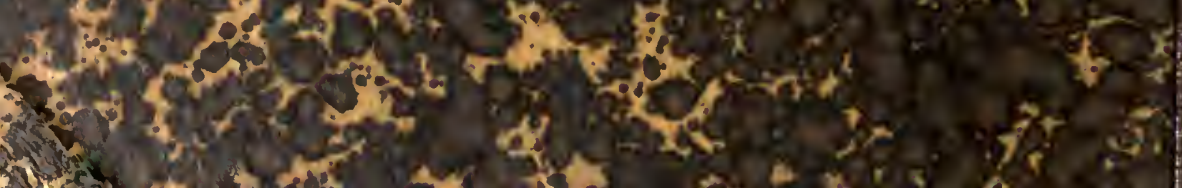
ave $7 y$ 9 r $\quad 63$ 